RPP-RPT-54815, Rev. 0

\title{
241-AZ Farm Annulus Extent of Condition Baseline Inspection
}

\author{
J.K. Engeman, C.L. Girardot, B.J. Vazquez \\ Washington River Protection Solutions \\ Richland, WA 99352 \\ U.S. Department of Energy Contract DE-AC27-08RV14800

$\begin{array}{lll}\text { EDT/ECN: } & \text { DRF } & \text { UC: N/A } \\ \text { Cost Center: } & \text { 2KE00 } & \text { Charge Code: } 201334 \\ \text { B\&R Code: } & \text { N/A } & \text { Total Pages: } 74\end{array}$

Key Words: tank integrity, corrosion, visual inspection, examination, integrity assessment

Abstract: This report provides the results of the comprehensive annulus visual inspection for tanks 241AZ-101 and 241-AZ-102 performed in fiscal year 2013. The inspection established a baseline covering about 95 percent of the annulus floor for comparison with future inspections. Any changes in the condition are also included in this document.

TRADEMARK DISCLAIMER. Reference herein to any specific commercial product, process, or service by trade name, trademark, manufacturer, or otherwise, does not necessarily constitute or imply its endorsement, recommendation, or favoring by the United States Government or any agency thereof or its contractors or subcontractors.

\section{APPROVED}

By Shauna Adams at 9:44 am, May 15, 2013

Release Approval
Date

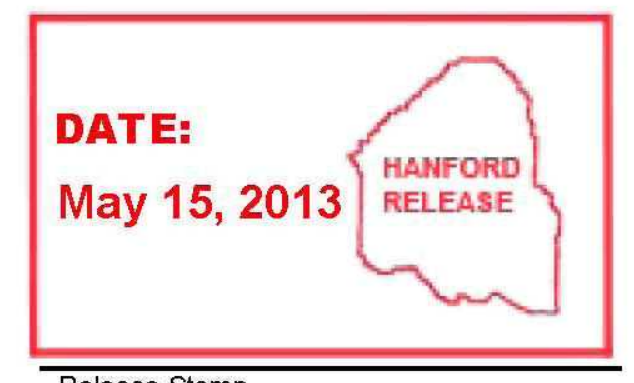

Release Stamp

\section{Approved For Public Release}




\title{
241-AZ Farm Annulus Extent of Condition Baseline Inspection
}

\author{
J. K. Engeman \\ C. L. Girardot \\ B. J. Vazquez \\ Washington River Protection Solutions
}

Date Published

May 2013

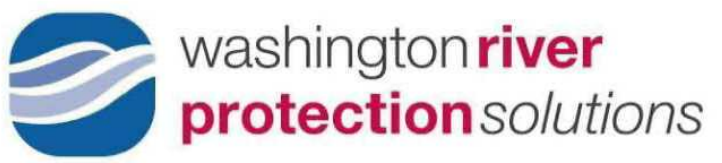

Prepared for the U.S. Department of Energy

Office of River Protection

Contract No.-DE-AC27-08RV14800 


\section{EXECUTIVE SUMMARY}

This document provides the results of the comprehensive annulus visual inspection for tanks 241-AZ-101 (AZ-101) and 241-AZ-102 (AZ-102) performed in fiscal year (FY) 2013. The main purpose of this inspection was to identify any anomalies, which would indicate the integrity of the primary tank is compromised. The inspection didn't find any such anomalies. In addition, the inspection establishes a baseline covering about 95 percent of the visually accessible annulus floor for comparison with future inspections. Hanford double-shell tanks contain radioactive, mixed waste. In order to minimize radiation hazards to operating personnel, a remote camera was deployed through risers to capture video footage of the annulus. Eleven risers were used for the current baseline inspections as shown in Figure ES-1 and Figure ES-2 for AZ-101 and AZ102 , respectively, which also identifies risers used in previous visual inspections.

The annulus visual inspections performed between January 2013 and February 2013 were reviewed and compared with previous inspections. The eleven-riser enhanced visual inspection of tanks AZ-101 and AZ-102 has not found any anomalies on the primary tank sidewall, lower knuckle, insulating refractory, refractory air-slots, stiffener ring, or annulus floor, which would be indicative of a primary tank leak. There is evidence of beachlines on the annulus floor as seen from many inspection risers which can be attributed to water couplant used during ultrasonic inspection examinations collecting on the annulus floor at some time and before it evaporated.

Annulus inspections identified small amounts of change on the annulus floor of tanks AZ-101 and AZ-102 (see Figure ES-3 and Figure ES-4, respectively) as compared to areas previously inspected. These changes are likely attributed to evaporated couplant water from UT examinations that occurred in nearby risers after the previous visual inspection. Additional stains were also identified on the annulus floor of tanks AZ-101 and AZ-102, however, these stains can be correlated back to existing equipment locations (e.g., annulus pump pit, riser penetrations, ENRAFs, etc.). Despite the changes identified in the current inspection, there was no evidence indicative of active water intrusion or a primary tank leak for tanks AZ-101 and AZ102.

In regions which did show a change in condition, these portions of the annulus floor were near risers utilized for UT examinations. All changes identified on the annulus floor shall be tracked in RPP-RPT-34310, Double-Shell Tank Integrity Inspection Report for AZ Tank Farm, as part of the double-shell tank visual inspection program.

To date, no evidence exists that would indicate either the containment or structural integrity have been compromised in tanks AZ-101 and AZ-102. Future annulus visual inspections and ultrasonic testing should be continued to identify any changes in the integrity of tanks AZ-101 and $\mathrm{AZ}-102$. 


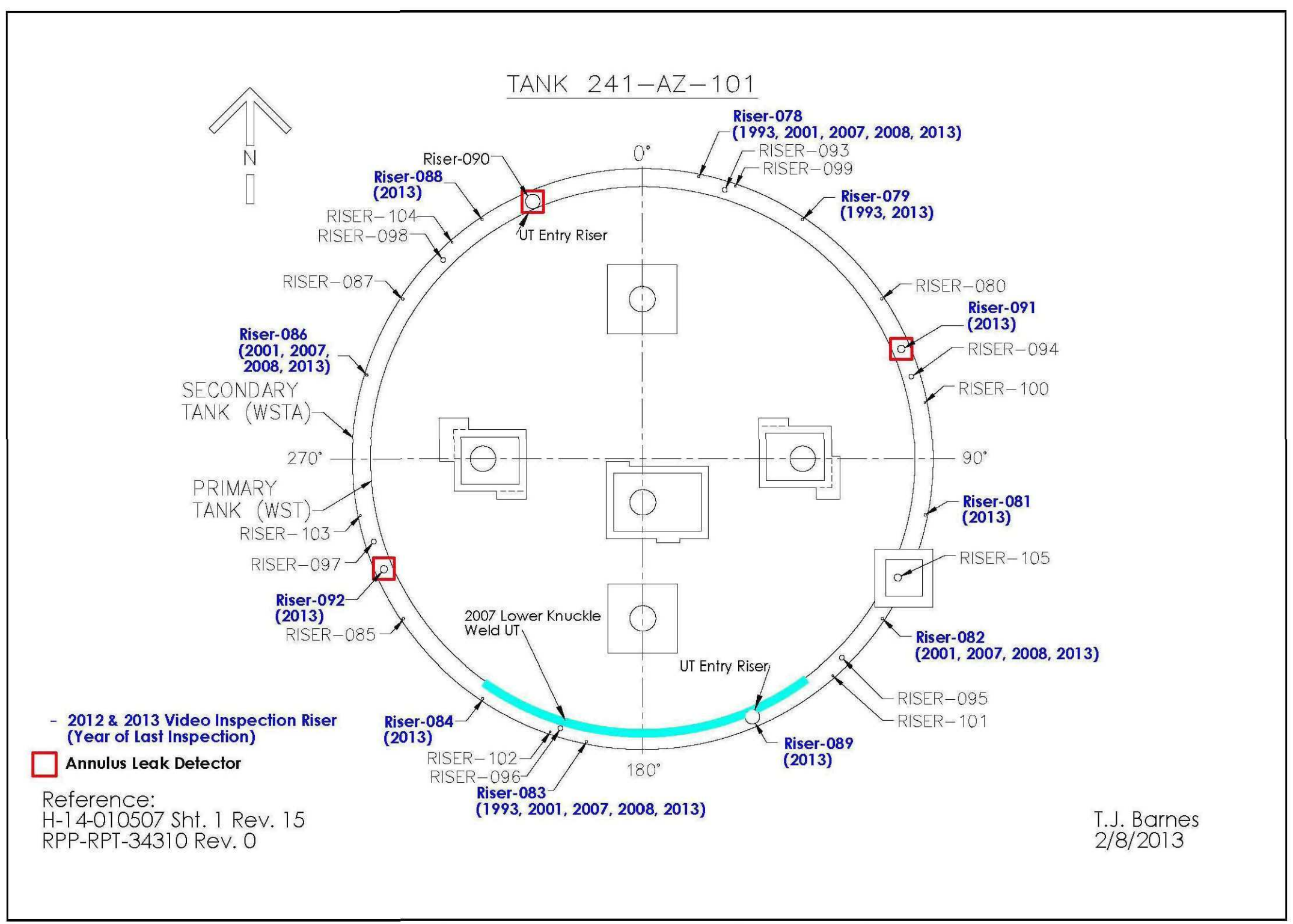

Figure ES-1. Tank AZ-101 Annulus Video Inspection Risers 
RPP-RPT-54815, Rev. 0

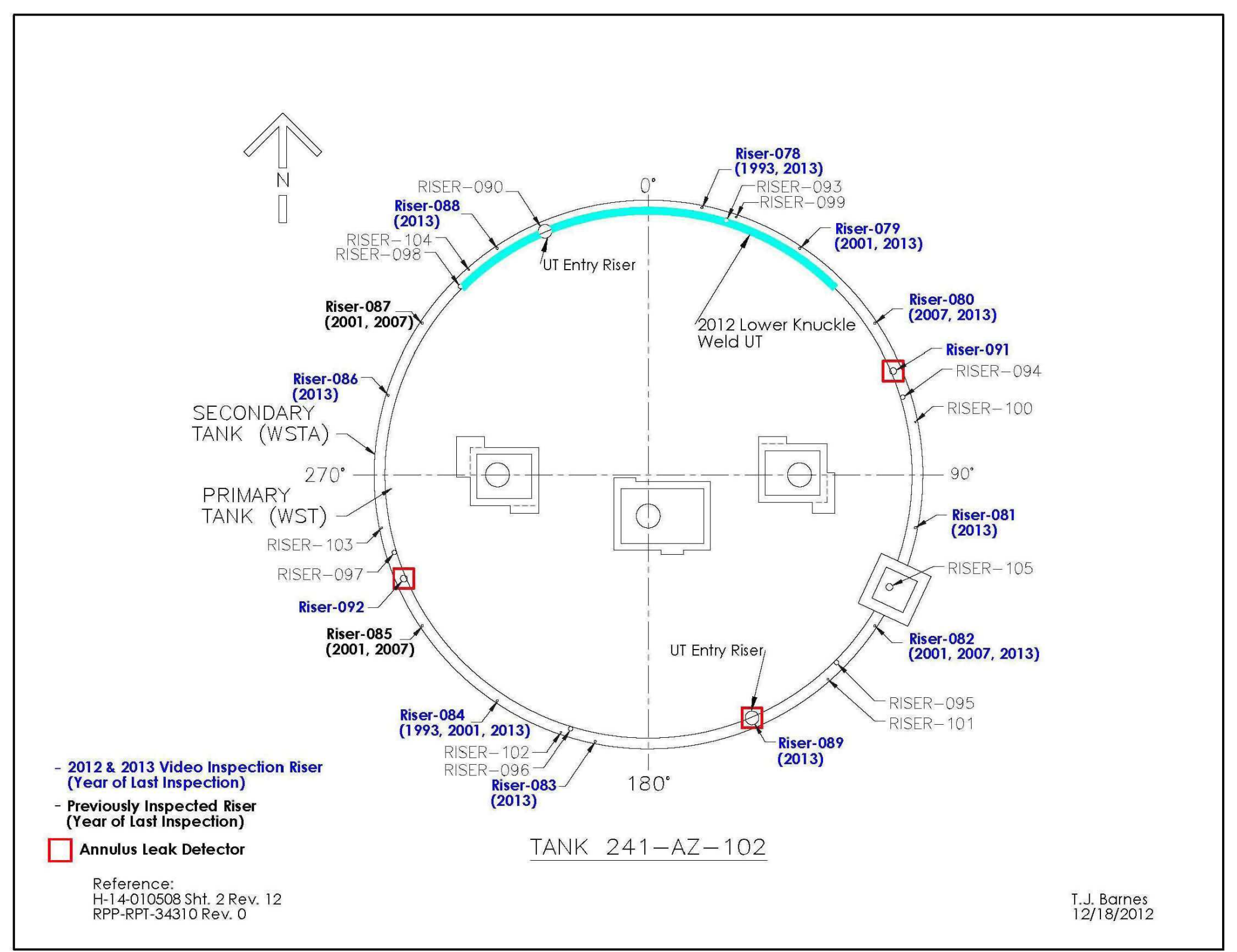

Figure ES-2. Tank AZ-102 Annulus Video Inspection Risers 


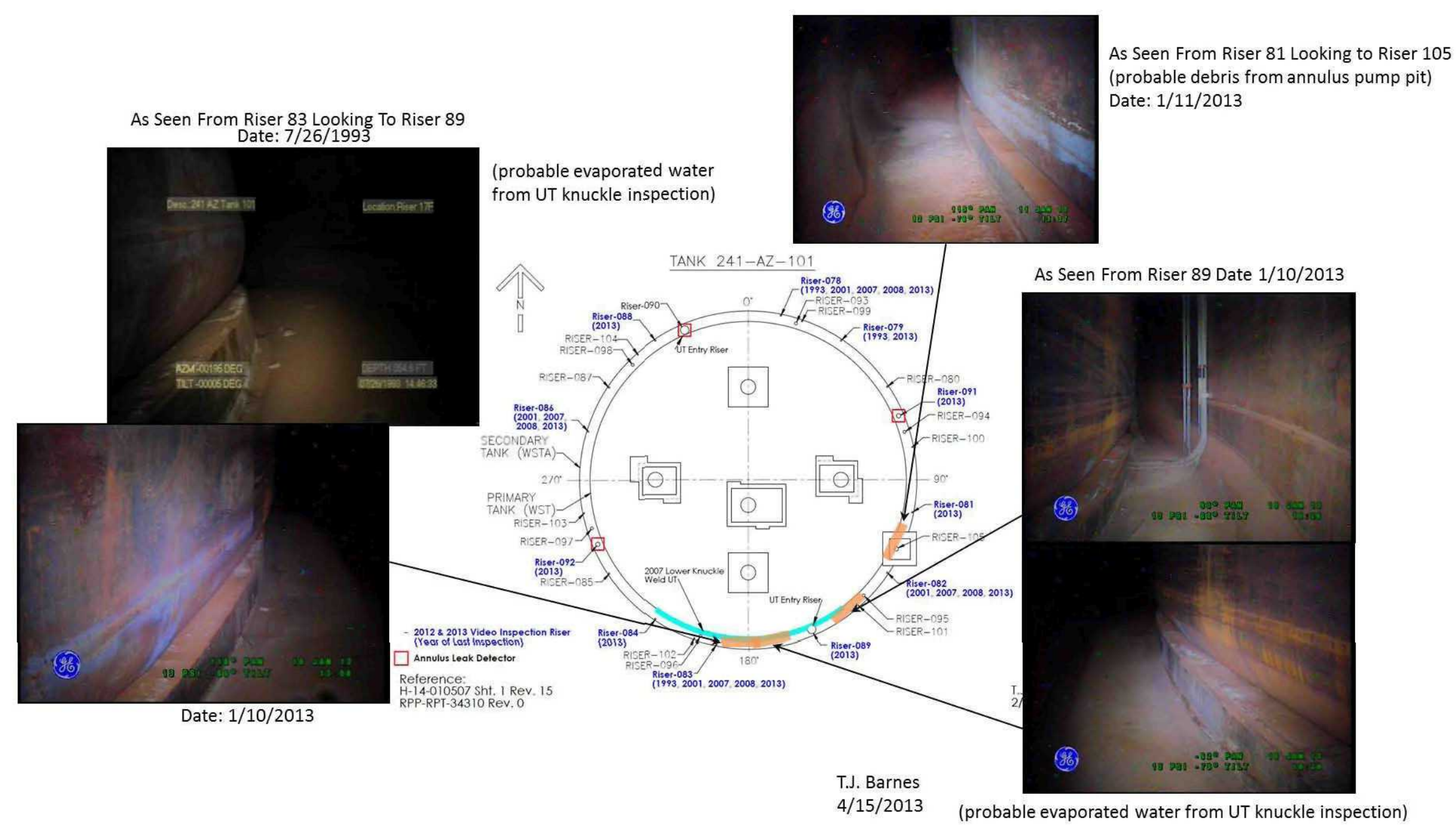

Figure ES-3. Tank AZ-101 Baseline Inspection Results Showing Additional Material on the Annulus Floor Attributed to Ultrasonic Inspections, ENRAF Installation, and Debris Accumulation 


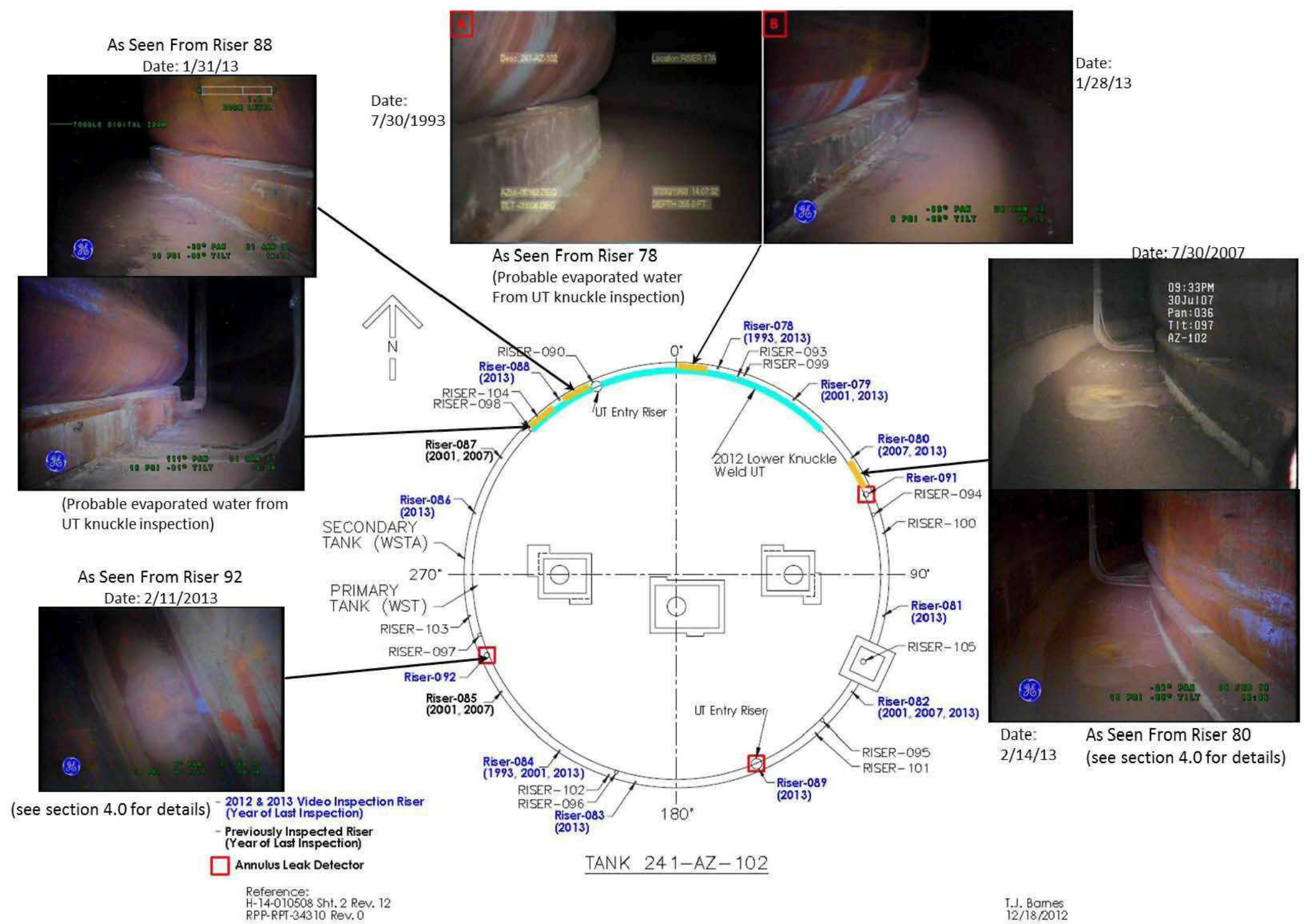

Figure ES-4. Tank AZ-102 Baseline Inspection Results Showing Additional Material on the Annulus Floor Attributed to Ultrasonic Inspections and ENRAF Installation 


\section{TABLE OF CONTENTS}

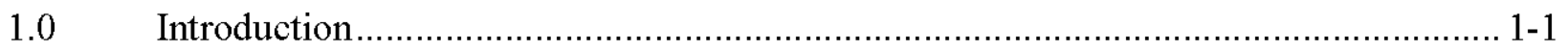

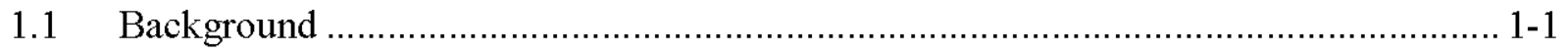

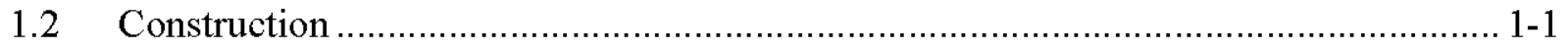

1.2.1 Primary Tank Wall Configuration ............................................................. 1-2

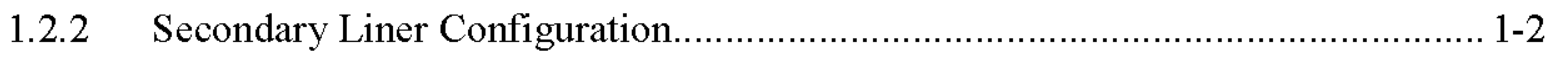

1.2.3 Reinforced Concrete Shell ............................................................... 1-3

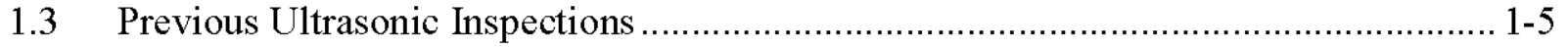

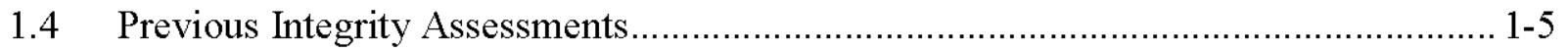

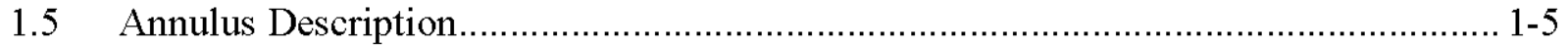

$2.0 \quad$ Tank AZ-101 Baseline Video Inspections ...................................................... 2-1

2.1 Tank AZ-101 Annulus Riser Inspections ........................................................ 2-1

2.2 Tank AZ-101 2013 Baseline Inspection Results and Comparisons to Previous

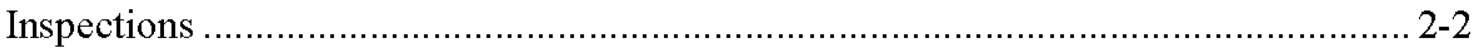

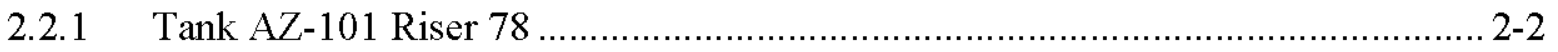

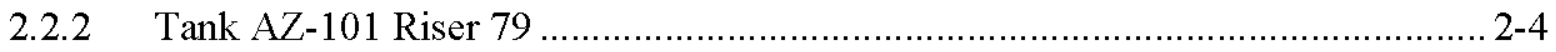

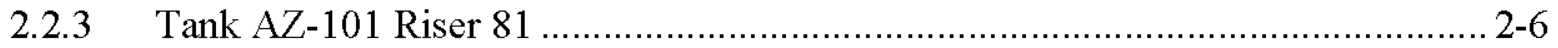

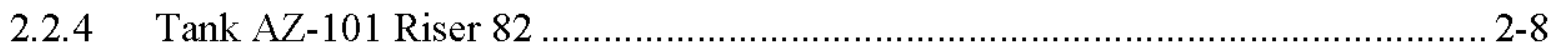

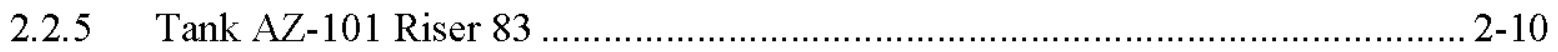

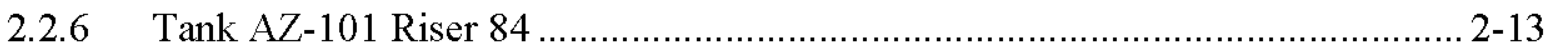

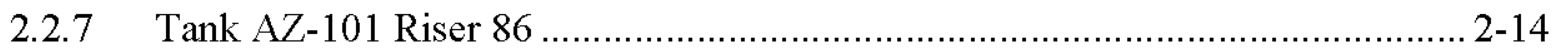

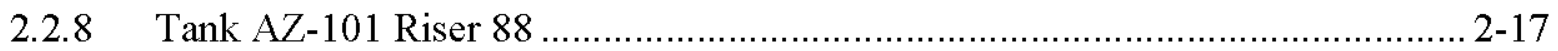

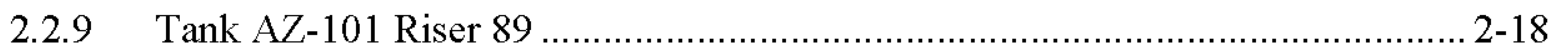

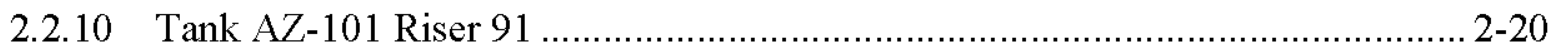

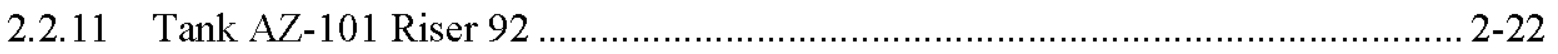

3.0 Tank AZ-102 Baseline Video Inspections ................................................. 3-1

3.1 Tank AZ-102 Annulus Riser Inspections .................................................. 3-1

3.2 Tank AZ-102 2013 Baseline Inspection Results and Comparisons to Previous

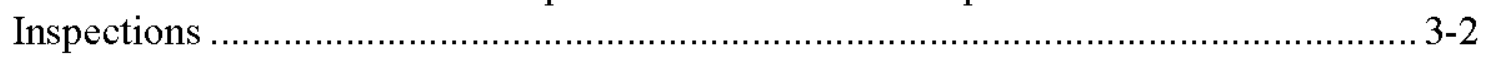

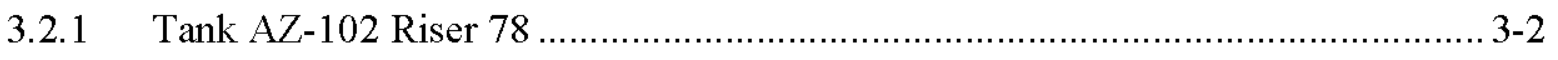

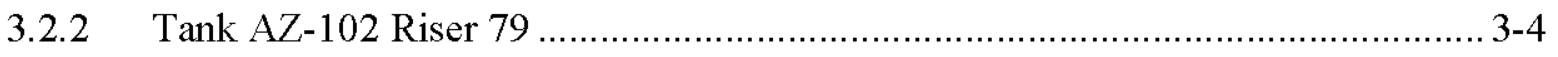

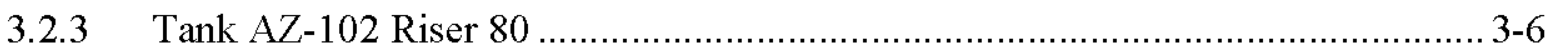

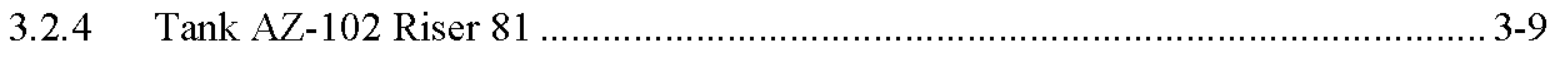

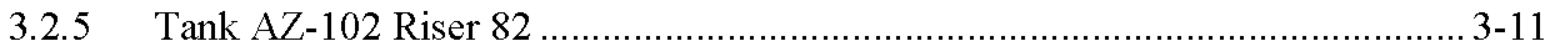




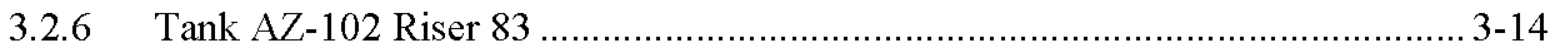

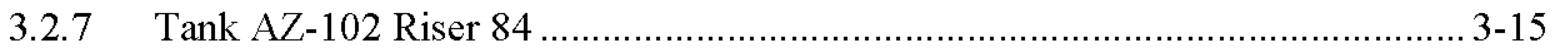

3.2.8 Tank AZ-102 Riser 86 ................................................................. 3-17

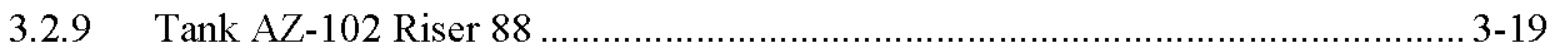

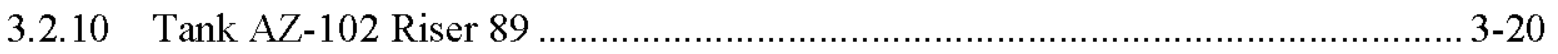

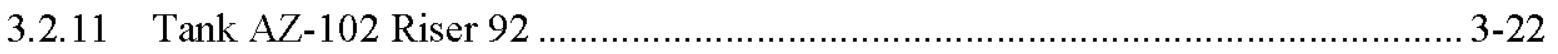

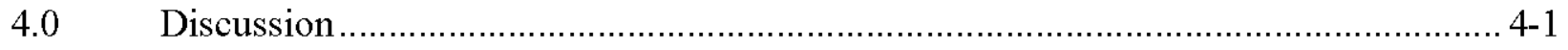

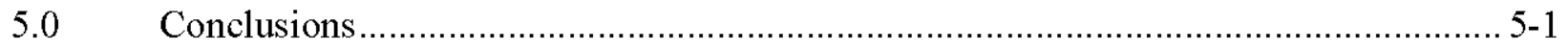

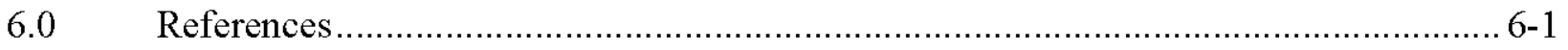

\section{LIST OF FIGURES}

Figure 1-1. Converging Section of the Primary Tank and Secondary Liner ........................... 1-3 Figure 1-2. Double-Shell Tank Concrete Encasement and Footing ...................................... 1-4 Figure 1-3. Typical Double-Shell Tank Annulus Description................................................. 1-6 Figure 1-4. 241-AZ Farm Tank Annulus Description Showing Refractory Slot (N1641598)... 1-6 Figure 2-1. Riser 78 Upper Haunch Comparisons Between Inspections on September 25, 2001 (A) and January 9, 2013 (B) Looking Towards Riser 93. 2-2

Figure 2-2. Riser 78 Upper Haunch Comparisons Between Inspections on September 25, 2001 (A) and January 9, 2013 (B) Looking Towards Riser 90. $2-3$

Figure 2-3. Riser 78 Lower Knuckle and Annulus Floor Comparisons Between Inspections on September 25, 2001 (A) and January 9, 2013 (B) Looking Towards Riser 93 .......... 2-3

Figure 2-4. Riser 78 Lower Knuckle and Annulus Floor Comparisons Between Inspections on September 25, 2001 (A) and January 9, 2013 (B) Looking Towards Riser 90 .......... 2-4

Figure 2-5. Riser 78 General Condition of the Refractory Slots on January 9, 2013 ............... 2-4

Figure 2-6. Riser 79 Upper Haunch Comparisons Between Inspections on July 22, 1993 (A)

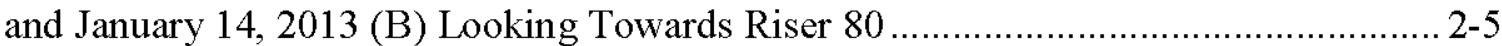

Figure 2-7. Riser 79 Upper Haunch Comparisons Between Inspections on July 22, 1993 (A) and January 14, 2013 (B) Looking Towards Riser $99 \ldots \ldots \ldots \ldots \ldots \ldots \ldots \ldots \ldots \ldots \ldots \ldots \ldots \ldots \ldots \ldots \ldots . . . . .2-5$

Figure 2-8. Riser 79 Lower Knuckle and Annulus Floor Condition on January 14, 2013 Looking Towards Riser 80 (A) and Looking Towards Riser 99 (B) ........................... 2-6

Figure 2-9. Riser 79 General Condition of the Refractory Slots on January 14, 2013 .............. 2-6 Figure 2-10. Riser 81 Upper Haunch Condition on January 11, 2013 Looking Towards Riser 105 (A) and Looking Towards Riser 100 (B) ……........................................ 2-7

Figure 2-11. Riser 81 Lower Knuckle and Annulus Floor Condition on January 11, 2013 Looking Towards Riser 105 (A) and Looking Towards Riser 100 (B) ....................... 2-7

Figure 2-12. Riser 81 Lower Knuckle and Annulus Floor Condition on January 11, 2013 ...... 2-8 Figure 2-13. Riser 82 Upper Haunch Comparisons Between Inspections on December 3, 2008 (A) and January 11, 2013 (B) Looking Towards Riser $95 \ldots \ldots \ldots \ldots \ldots \ldots \ldots \ldots \ldots \ldots \ldots \ldots \ldots \ldots . . .2-8$

Figure 2-14. Riser 82 Upper Haunch Comparisons Between Inspections on December 3, 2008 (A) and January 11, 2013 (B) Looking Towards Riser 105 ...................................... 2-9

Figure 2-15. Riser 82 Lower Knuckle and Annulus Floor Comparisons Between Inspections on September 26, 2001 (A) and January 11, 2013 (B) Looking Towards Riser 95 ........ 2-9 
Figure 2-16. Riser 82 Lower Knuckle and Annulus Floor Comparisons Between Inspections on September 26, 2001 (A) and January 11, 2013 (B) Looking Towards Riser 105 .... 2-10 Figure 2-17. Riser 82 General Condition of the Refractory Slots on January 11, 2013 ........ 2-10 Figure 2-18. Riser 83 Upper Haunch Comparisons Between Inspections on July 26, 1993 (A) and January 10, 2013 (B) Looking Towards Riser 96

Figure 2-19. Riser 83 Upper Haunch Comparisons Between Inspections on September 26, 2001 (A) and January 10, 2013 (B) Looking Towards Riser 89 2-11

Figure 2-20. Riser 83 Lower Knuckle and Annulus Floor Comparisons Between Inspections on July 26, 1993 (A) and January 10, 2013 (B) Looking Towards Riser 96. $2-12$

Figure 2-21. Riser 83 Lower Knuckle and Annulus Floor Comparisons Between Inspections on July 26, 1993 (A) and January 10, 2013 (B) Looking Towards Riser 89 .............. 2-12

Figure 2-22. Riser 83 General Condition of the Refractory Slots on January 10, 2013 ......... 2-13 Figure 2-23. Riser 84 General Condition of the Upper Haunch on January 14, 2013

Looking Towards Riser 85 (A) and Looking Towards Riser 102 (B) ....................... 2-13

Figure 2-24. Riser 84 Lower Knuckle and Annulus Floor Condition on January 14, 2013

Looking Towards Riser 85 (A) and Looking Towards Riser 102 (B) ........................ 2-14

Figure 2-25. Riser 84 General Condition of the Refractory Slots on January 14, 2013 ......... 2-14

Figure 2-26. Riser 86 Upper Haunch Comparisons Between Inspections on September 25, 2001

(A) and January 7, 2013 (B) Looking Towards Riser 87

Figure 2-27. Riser 86 Upper Haunch Comparisons Between Inspections on September 25, 2001

(A) and January 7, 2013 (B) Looking Towards Riser 103 2-15

Figure 2-28. Riser 86 Lower Knuckle and Annulus Floor Comparisons Between Inspections

on September 25, 2001 (A) and January 7, 2013 (B) Looking Towards Riser 87 ....... 2-16

Figure 2-29. Riser 86 Lower Knuckle and Annulus Floor Comparisons Between Inspections

on September 25, 2001 (A) and January 7, 2013 (B) Looking Towards Riser 103 ..... 2-16

Figure 2-30. Riser 86 General Condition of the Refractory Slots on January 7, 2013 ........... 2-17

Figure 2-31. Riser 88 General Condition of the Upper Haunch on January 9, 2013

Looking Towards Riser 90 (A) and Looking Towards Riser 104 (B) ....................... 2-17

Figure 2-32. Riser 88 Lower Knuckle and Annulus Floor Condition on January 9, 2013

Looking Towards Riser 90 (A) and Looking Towards Riser 104 (B) ....................... 2-18

Figure 2-33. Riser 88 General Condition of the Refractory Slots on January 9, 2013 ........... 2-18

Figure 2-34. Riser 89 General Condition of the Upper Haunch on January 10, 2013

Looking Towards Riser 83 (A) and Looking Towards Riser 101 (B) ...................... 2-19

Figure 2-35. Riser 89 Lower Knuckle and Annulus Floor Condition on January 10, 2013

Looking Towards Riser 83 (A) and Looking Towards Riser 101 (B) ....................... 2-20

Figure 2-36. Riser 89 General Condition of the Refractory Slots on January 10, 2013 ......... 2-20

Figure 2-37. Riser 91 General Condition of the Upper Haunch on January 15, 2013

Looking Towards Riser 94 (A) and Looking Towards Riser 80 (B) ....................... 2-21

Figure 2-38. Riser 91 Lower Knuckle and Annulus Floor Condition on January 15, 2013

Looking Towards Riser 94 (A) and Looking Towards Riser 80 (B) ........................ 2-21

Figure 2-39. Riser 91 General Condition of the Refractory Slots on January 15, 2013 ......... 2-22

Figure 2-40. Riser 92 General Condition of the Upper Haunch on January 8, 2013

Looking Towards Riser 97 (A) and Looking Towards Riser 85 (B) ........................ 2-22

Figure 2-41. Riser 92 Lower Knuckle and Annulus Floor Condition on January 8, 2013

Looking Towards Riser 97 (A) and Looking Towards Riser 85 (B) ........................ 2-23

Figure 2-42. Riser 92 General Condition of the Refractory Slots on January 8, 2013 ........... 2-23 
Figure 3-1. Riser 78 Upper Haunch Comparisons Between Inspections on July 30, 1993 (A) and January 28, 2013 (B) Looking Towards Riser 93.

Figure 3-2. Riser 78 Upper Haunch Comparisons Between Inspections on July 30, 1993 (A) and January 28, 2013 (B) Looking Towards Riser 90.

Figure 3-3. Riser 78 Lower Knuckle and Annulus Floor Comparisons Between Inspections on July 30, 1993 (A) and January 28, 2013 (B) Looking Towards Riser 93

Figure 3-4. Riser 78 Lower Knuckle and Annulus Floor Comparisons Between Inspections on July 30, 1993 (A) and January 28, 2013 (B) Looking Towards Riser 90.

Figure 3-5. Riser 78 General Condition of the Refractory Slots on July 30, 1993 (A) and

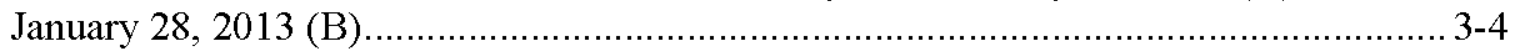

Figure 3-6. Riser 79 General Condition of the Upper Haunch on January 13, 2013 Looking Towards Riser 80 (A) and Looking Towards Riser 99 (B) ...................................... 3-5

Figure 3-7. Riser 79 Lower Knuckle and Annulus Floor Comparisons Between Inspections on February 6, 2001 (A) and January 23, 2013 (B) Looking Towards Riser 80 ........... 3-5

Figure 3-8. Riser 79 Lower Knuckle and Annulus Floor Comparisons Between Inspections on February 6, 2001 (A) and January 23, 2013 (B) Looking Towards Riser 99 ............ 3-6

Figure 3-9. Riser 79 General Condition of the Refractory Slots on January 23, 2013 ............ 3-6

Figure 3-10. Riser 80 Upper Haunch Comparisons Between Inspections on July 30, 2007 (A)

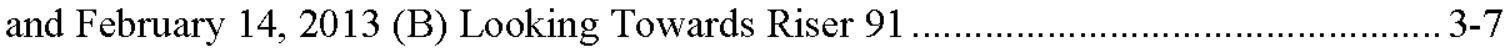

Figure 3-11. Riser 80 Upper Haunch Comparisons Between Inspections on July 30, 2007 (A) and February 14, 2013 (B) Looking Towards Riser 79.

Figure 3-12. Riser 80 Lower Knuckle and Annulus Floor Comparisons Between Inspections on July 30, 2007 (A), July 29, 2011 (B), and February 14, 2013 (C) Looking Towards Riser 91

Figure 3-13. Riser 80 Lower Knuckle and Annulus Floor Comparisons Between Inspections on July 30, 2007 (A) and February 14, 2013 (B) Looking Towards Riser 79 ............... 3-9

Figure 3-14. Riser 80 General Condition of the Refractory Slots on July 30, 2007 (A) and February 14, 2013 (B).

Figure 3-15. Riser 81 General Condition of the Upper Haunch on January 22, 2013 Looking Towards Riser 105 (A) and Looking Towards Riser 100 (B).

Figure 3-16. Riser 81 Lower Knuckle and Annulus Floor Condition on January 22, 2013 Looking Towards Riser 105 (A) and Looking Towards Riser 100 (B)..... 3-11

Figure 3-17. Riser 81 Lower Knuckle and Annulus Floor Condition on January 22, 2013 ..... 3-11

Figure 3-18. Riser 82 Upper Haunch Comparisons Between Inspections on February 8, 2001 (A) and January 22, 2013 (B) Looking Towards Riser 105 and on January 22, 2013 Looking Towards Riser 95 (C).... $3-12$

Figure 3-19. Riser 82 Lower Knuckle and Annulus Floor Comparisons Between Inspections on February 8, 2001 (A) and January 22, 2013 (B) Looking Towards Riser 95 .......... 3-13

Figure 3-20. Riser 82 Lower Knuckle and Annulus Floor Comparisons Between Inspections on February 8, 2001 (A) and January 22, 2013 (B) Looking Towards Riser 105 ........ 3-13

Figure 3-21. Riser 82 General Condition of the Refractory Slots on January 22, 2013 .......... 3-13

Figure 3-22. Riser 83 General Condition of the Upper Haunch on February 5, 2013 Looking Towards Riser 96 (A) and Looking Towards Riser 89 (B) ......................... 3-14

Figure 3-23. Riser 83 Lower Knuckle and Annulus Floor Condition on February 5, 2013 Looking Towards Riser 96 (A) and Looking Towards Riser 89 (B) ........................... 3-15

Figure 3-24. Riser 83 General Condition of the Refractory Slots on February 5, 2013 .......... 3-15 
Figure 3-25. Riser 84 General Condition of the Upper Haunch on February 5, 2013

Looking Towards Riser 85 (A) and Looking Towards Riser 102 (B) 3-16

Figure 3-26. Riser 84 Lower Knuckle and Annulus Floor Comparisons Between Inspections

on July 27, 1993 (A) and February 5, 2013 (B) Looking Towards Riser 85. 3-16

Figure 3-27. Riser 84 Lower Knuckle and Annulus Floor Comparisons Between Inspections on July 27, 1993 (A) and February 5, 2013 (B) Looking Towards Riser 102 ............. 3-17

Figure 3-28. Riser 84 General Condition of the Refractory Slots on February 5, 2013 ..........3-17

Figure 3-29. Riser 86 General Condition of the Upper Haunch on January 31, 2013

Looking Towards Riser 87 (A) and Looking Towards Riser 103 (B) ....................... 3-18

Figure 3-30. Riser 86 Lower Knuckle and Annulus Floor Condition on January 31, 2013

Looking Towards Riser 87 (A) and Looking Towards Riser 103 (B) ....................... 3-18

Figure 3-31. Riser 86 General Condition of the Refractory Slots on January 31, 2013 ......... 3-19

Figure 3-32. Riser 88 General Condition of the Upper Haunch on January 31, 2013

Looking Towards Riser 90 (A) and Looking Towards Riser 104 (B).

Figure 3-33. Riser 88 Lower Knuckle and Annulus Floor Condition on January 31, 2013

Looking Towards Riser 90 (A) and Looking Towards Riser 104 (B) ........................ 3-20

Figure 3-34. Riser 88 General Condition of the Refractory Slots on January 31, 2013 ......... 3-20

Figure 3-35. Riser 89 General Condition of the Upper Haunch on February 27, 2013

Looking Towards Riser 83 (A) and Looking Towards Riser 101 (B).

Figure 3-36. Riser 89 Lower Knuckle and Annulus Floor Condition on February 27, 2013

Looking Towards Riser 83 (A) and Looking Towards Riser 101 (B) ......................... 3-22

Figure 3-37. Riser 89 General Condition of the Refractory Slots on February 27, 2013 ........ 3-22

Figure 3-38. Riser 92 General Condition of the Upper Haunch on February 11, 2013

Looking Towards Riser 97 (A) and Looking Towards Riser 85 (B).

Figure 3-39. Riser 92 Lower Knuckle and Annulus Floor Condition on February 11, 2013

Looking Towards Riser 97 (A) and Looking Towards Riser 85 (B) ........................ 3-23

Figure 3-40. Riser 92 General Condition of the Refractory Slots on February 11, 2013 ........ 3-24

Figure 4-1. Top Down View of the Annulus Floor as seen from Riser 92 on

February 11, 2013.

Figure 4-2. Annulus Floor Discoloration in Tank AZ-102 as seen from Riser 92 in 2013 (A), from Riser 80 in 2013 (B), from Riser 80 in 2011 (C), and Close Up View Showing Elevation Differences as seen from Riser 80 in 2011 (D).

\section{LIST OF TABLES}

Table 2-1. Tank AZ-101 Annulus Riser Visual Inspections

Table 3-1. Tank AZ-102 Annulus Riser Visual Inspections 
RPP-RPT-54815, Rev. 0

\section{LIST OF TERMS}

\begin{tabular}{|c|c|}
\hline \multicolumn{2}{|c|}{ Abbreviations and Acronyms } \\
\hline 241-AY-102 & AY -102 \\
\hline 241-AZ-101 & AZ-101 \\
\hline 241-AZ-102 & AZ-102 \\
\hline DST & Double-shell tank \\
\hline EFCOG & U.S. Department of Energy's Energy Facilities Contractors Group \\
\hline $\mathrm{EOC}$ & Extent of Condition \\
\hline FY & Fiscal Year \\
\hline PUREX & Plutonium-Uranium Reduction Extraction Facility \\
\hline UT & Ultrasonic inspection \\
\hline WRPS & Washington River Protections Solutions \\
\hline \multicolumn{2}{|l|}{ Units } \\
\hline${ }^{\circ} \mathrm{F}$ & Degree Fahrenheit \\
\hline $\mathrm{ksi}$ & Kilopound per square inch \\
\hline psi & pounds per square inch \\
\hline
\end{tabular}




\subsection{INTRODUCTION}

This document provides the results of the comprehensive annulus inspection for tanks 241-AZ101 (AZ-101) and 241-AZ-102 (AZ-102) performed in fiscal year (FY) 2013. The purpose of this inspection was to identify any anomalies, which would indicate the integrity of the primary tank is compromised, and form a reference visual baseline covering $\sim 95 \%$ of the annulus floor area for comparison with future inspections. Any areas of interest identified during the inspections are also noted. The results of the inspections shall be incorporated into RPP-RPT34310, Double-Shell Tank Integrity Inspection Report for 241-AZ Tank Farm, which contains

previous visual inspections of tanks AZ-101 and AZ-102. This enhanced inspection establishes a baseline condition of the primary tank for comparison with future inspections.

\subsection{BACKGROUND}

In October 2012, it was determined that the primary tank of double-shell tank (DST) 241-AY-102 (AY-102) was leaking (RPP-ASMT-53793, Rev. 0, Tank 241-AY-102 Leak Assessment Report). Following identification of the tank AY-102 probable leak cause, an Extent of Condition (EOC) evaluation was prepared using U.S. Department of Energy's Energy Facilities Contractors Group (EFCOG) Guidance for Extent of Conditions Evaluations. The EFCOG process was used to identify other DSTs with construction, waste storage, or thermal histories similar to that of tank AY-102 (WRPS-1204931, Double-Shell Tank 241-AY-102 Primary Tank Leak Extent of Condition Evaluation and Recommended Annulus Visual Inspection Intervals).

The EOC evaluation also considered the adequacy of the existing annulus inspection frequency with respect to the circumstances of the tank AY-102 leak and the advancing age of the DST structures. The evaluation concluded that the interval between annulus inspections should be shortened for all DSTs, with each tank's inspection interval reflecting its age and the extent to which the tank shares similar construction and operating history with tank AY-102. Six tanks were identified for the enhanced video inspections: 241-AY-101, AZ-101, AZ-102, 241-SY-101, 241-SY-102, and 241-SY-103. To effect the transition to a shortened inspection interval, each tank would require a baseline inspection, covering $>95 \%$ of annulus floor area, and the portion of the primary tank (i.e., dome, sidewall, lower knuckle, and insulating refractory) that is visible from the annulus inspection risers.

\subsection{CONSTRUCTION}

Construction of the two 241-AZ Farm tanks by Pittsburg Des Moines Steel Co. began in 1971 and was completed in early 1974. This tank farm was constructed following the construction of 241-AY Farm. In 1976 241-AZ Farm was placed into service.

Each DST consists of a carbon-steel primary tank surrounded by a secondary carbon-steel liner anchored to a steel reinforced-concrete shell. The primary tanks, although never certified to the pressure vessel code, were designed using the general criteria of $A S M E$ Boller and Pressure 
Vessel Code, Section VIII, Div. 2 (1965), and fabricated and constructed using ASTM ${ }^{1}$ A515, grade- 60 carbon steel of $32 \mathrm{ksi}$ yield strength, and $60 \mathrm{ksi}$ ultimate tensile strength. After fabrication, the tanks were stress relieved at $1000^{\circ} \mathrm{F}$ to $1100^{\circ} \mathrm{F}$ to reduce or eliminate welding and fabrication stresses to minimize the potential for stress corrosion cracking.

\subsubsection{Primary Tank Wall Configuration}

The primary tank of each DST measures 75 feet in diameter (measured from the centerline of the steels plates composing the cylindrical section) and 46.8 feet high at the dome center. The tanks in 241-AZ Farm have a nominal capacity of $1 \mathrm{Mgal}$, with a maximum waste depth of 30.3 feet and a design maximum specific gravity of 1.6 in the liquid and 2.5 in the solids. The waste depth corresponds to the height of the three side fill lines into the tank from the Plutonium-Uranium Reduction Extraction Facility (PUREX).

An insulating refractory pad is located between the primary and secondary tank floors. The concrete pad is made of Kaolite 2000 and includes air distribution and drain slots in a grid pattern, which, among other things, allows potential leaks to be drained into the tank annulus where leak-detection instrumentation is installed. See drawing H-2-67317, Tanks $101 \& 102$ Section \& Detalls 241-AZ Tank Farm.

The primary tank bottom consists of two thicknesses of plate. A 1 inch thick steel plate, 4 feet in diameter, is located at the center of the tank bottom. The bottom plate transitions to a 0.375 inch thick plate at the interfacing weld and extends 31 feet 6 inches to a curved, formed section of a 0.875 inch thick plate, referred to as the "primary bottom knuckle" in construction records. This curved plate rises approximately 1 foot above the tank bottom, and then joins to another 0.875 inch thick plate, referred to in construction records as a "bottom transition plate." The bottom transition plate extends 2 feet beyond the bottom knuckle.

Above the bottom knuckle and transition plate are three courses of plates that make up the primary tank wall. The first of these is 0.75 inches thick, and is welded directly to the bottom transition plate. This series of wall plates is referred to as "Course 1" in construction records. The two series of wall plates above Course 1 are referred to as "Course 2" and then "Course 3," respectively. Course 1 is 9 feet in height, while Courses 2 and 3 are 9 feet 10 inches in height, but are 0.5 inches thick. Above Course 3 is a 0.375 inch thick, 3 feet 9 inches tall course of plates referred to as the "top transition plate." This transition plate is directly welded to the "top knuckle" plates of the primary tank, which are 0.375 inches thick and are welded to the tank dome. The tank dome center is a 0.5 inch thick plate, 12 feet in diameter, and transitions to a 0.375 inch thick plate making up the majority of the elliptically curved region.

During hydrostatic testing of the primary tank, chalk was placed over the welds on the outside of the primary tank for leak detection purposes. This chalk can appear as blue streaks along the welds that are visible during inspections.

\subsubsection{Secondary Liner Configuration}

\footnotetext{
${ }^{1}$ ASTM 1s a registered trademark of Amerıcan Society for Testıng and Materials
} 
The secondary liner lies beneath the insulating refractory and is built directly on top of a concrete foundation. The secondary liner is 80 feet in diameter, resulting in a $2 \frac{1}{2}$ foot wide annular space between the primary and secondary tanks. The secondary liner is not directly joined to the primary tank. Instead 14 inch wide 18 gauge flashing strips are tack welded to the primary tank and are used to cover the $1 / 2$ inch gap between the primary and secondary shells (see Figure 1-1)

The secondary liner extends along the bottom, sides, and upper haunch of the concrete shell and is constructed entirely of 0375 inch thick carbon steel plate. The secondary floor transitions to the "secondary bottom knuckle" extends 1 foot up from the floor where it is welded to a 2 foot "secondary bottom transition plate"

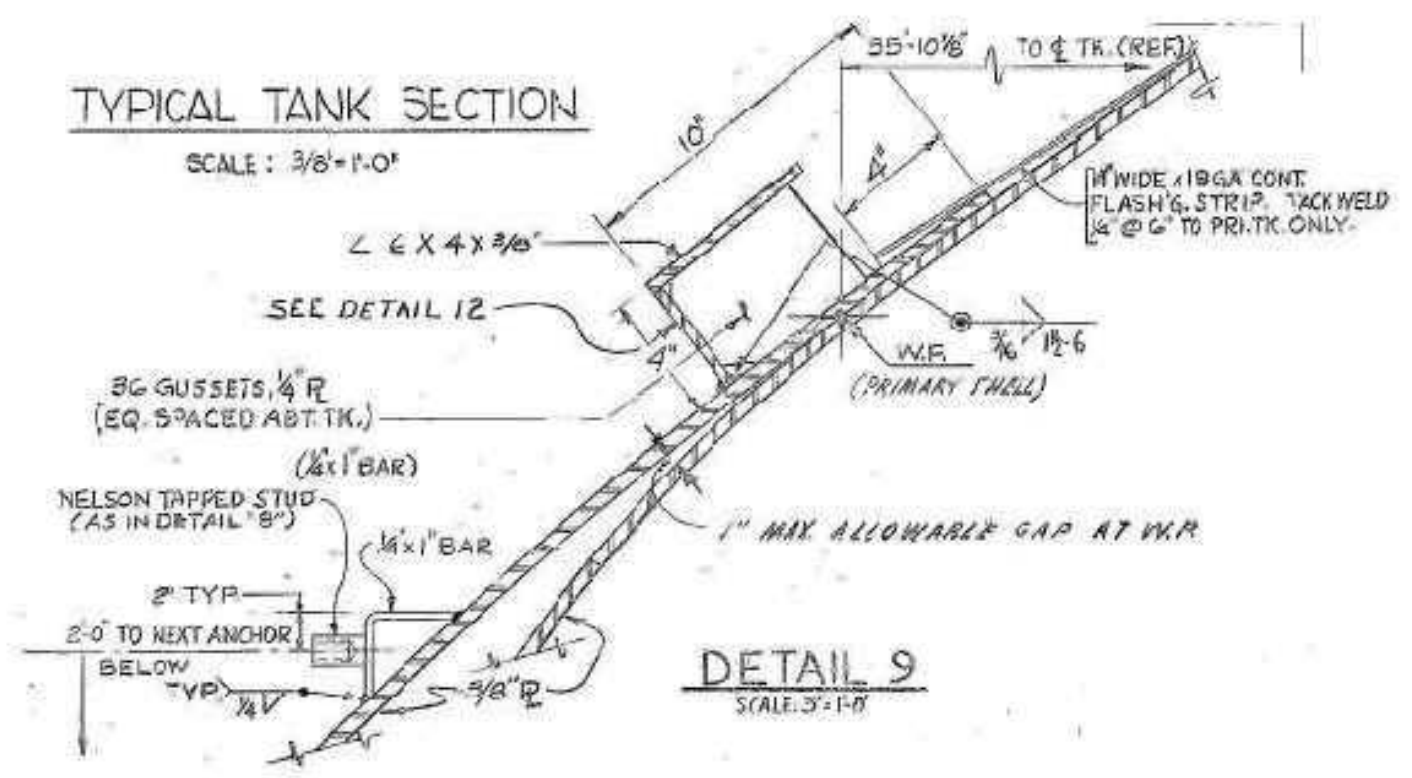

Figure 1-1. Converging Section of the Primary Tank and Secondary Liner

The vertical section of the secondary liner is made up of four courses, with Course 1 at the bottom, then transitioning up to Course 2, Course 3 , and finally Course 4 All four courses are 7 feet 7-7/8 inches in height

The top of the secondary tank is capped with a ring of "secondary top knuckle" plates that bend inw ard to fit underneath the 18 gauge flashing which is tack welded to the primary tank dome. This flashing provides a limited amount of cover to prevent debris from entering the annulus space. Approximately 4 inches of flashing overlaps the secondary wall as seen in Figure 1-1

\subsubsection{Reinforced Concrete Shell}

On the outside of the secondary liner is a steel reinforced-concrete shell composed of various types of concrete all meeting or surpassing a 3000 psi compressive strength. The exterior concrete shell comprises a foundation, wall, and dome that completely enclose the secondary shell and primary tank dome. The structural concrete foundation is 88 feet 6 inches in diameter and is designed to distribute all weight loads uniformly to the ground below. The circular center portion of the foundation is 6 feet in diameter and 2 feet thick. From the circular center portion, the foundation thickness tapers to a 1 foot thickness and then expands to a thickness of 2 feet at 
the outer edge. The structural foundation contains slots to collect any leakage from the secondary tank. Any leakage that reaches the foundation drains though the slots to a leakdetection pit monitored for changes in liquid level indicative of leakage. See drawing H-267245 , Concrete Tank Section \& Haunch Reinforcement, for details.

The concrete shell is 83 feet in outside diameter and 1.5 feet thick and rests on steel plates supported by the tank foundation (see Figure 1-2). The concrete shell was poured directly against the secondary tank (i.e, the secondary liner was used as a casting form for the concrete shell). The dome is 1.25 feet thick and is constructed of steel-reinforced concrete. J-Bolts are threaded into tapped studs welded to the secondary steel liner and dome and are cast into the concrete (see Figure 1-2).

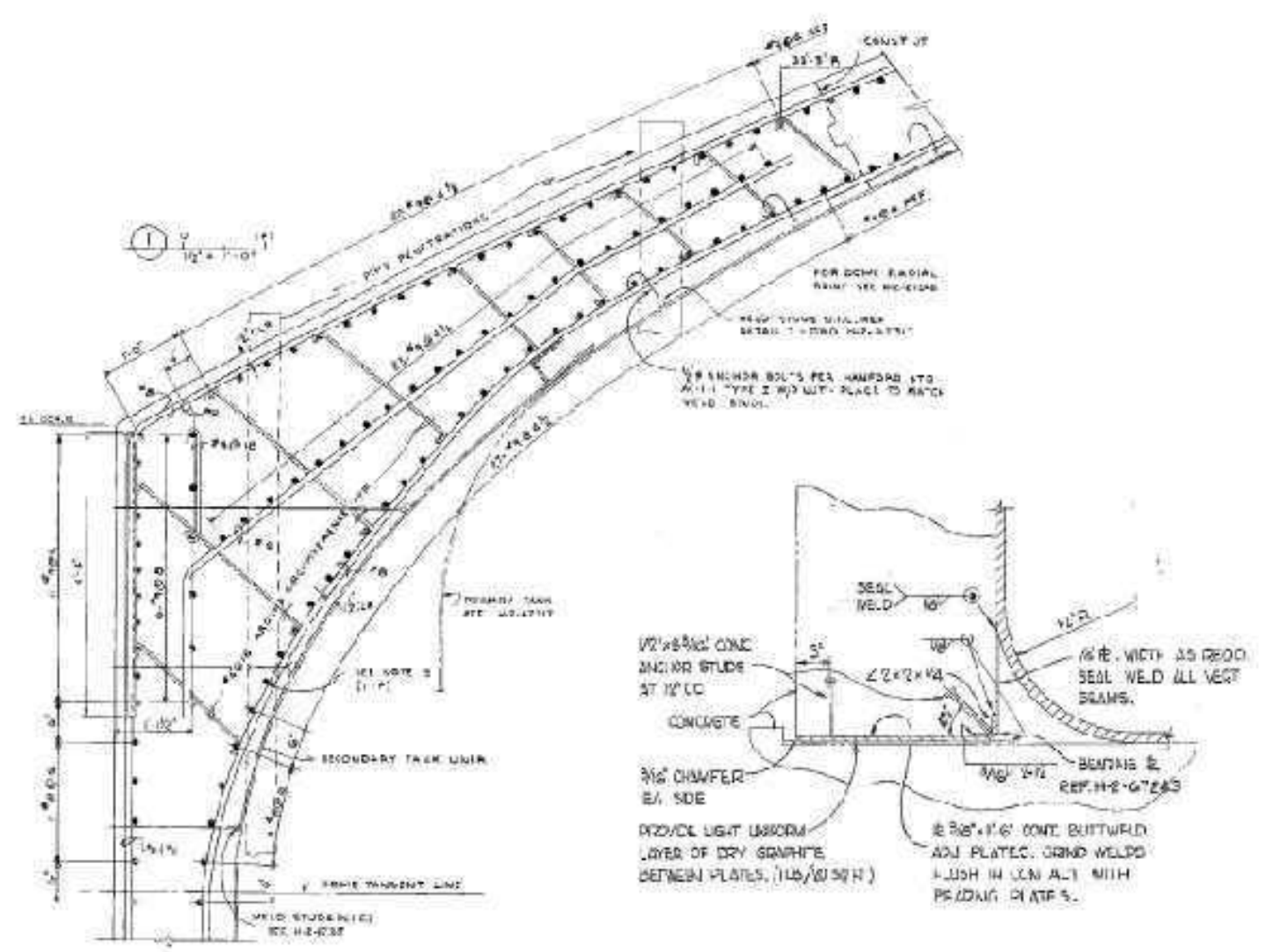

Figure 1-2. Doub le-Shell Tank Concrete Encasement and Footing

Steel riser pipes penetrate the concrete dome and the top of the primary tank and secondary liner. The risers provide access to the primary tank and the annulus space for waste transfer operations, equipment installations, and monitoring. The risers terminate in covered pits or above grade. The AZ-101 and AZ-102 dome penetration views as shown in draw ing H-14-010507 Sheets 1 and 2, respectively, show the riser configurations and other tank features. 
RPP-RPT-54815, Rev. 0

\subsection{PREVIOUS ULTRASONIC INSPECTIONS}

The inspection of the primary tank walls is done through the use of a P-scan crawler. The crawler is a remote controlled device that delivers the ultrasonic transducers to the tank walls. The crawler is deployed through a 24 inch annulus inspection riser and is attached to the tank wall with two pairs of magnetic wheels. To collect wall measurement data, the crawler is slowly moved forward as the crawler's transducers glide from side-to-side over the tank wall surface. The crawler uses water as the transducer couplant to the metal sidewall. Approximately 130 to 150 gallons of water is used for each plate scanned and typically 23 scans are performed per tank. The water accumulates and extends along the annulus floor, evaporates, and leaves behind white beachlines that can be misinterpreted as leak evidence. Depending on the duration between scans, beachlines can be located a couple inches above the annulus floor along the secondary liner.

Ultrasonic inspection (UT) of the tank AZ-101 primary tank wall was initially performed in 1999 via Riser 89 (HNF-4819, Final Results of DST 241-AZ-101 Ultrasonic Inspection). Tank AZ101 was next examined in 2007 via Risers 89 and 90 and results are reported in RPP-RPT34264, Rev. 0, Ultrasonic Inspection Results for Double-Shell Tank 241-AZ-101.

Ultrasonic inspection of the tank AZ-102 primary tank wall was initially performed in 2003 utilizing Riser 90 (RPP-15765, Ultrasonic Inspection Results for Double-Shell Tank 241-AZ102- FY2003). Tank AZ-102 was next examined in 2012 via Risers 89 and 90 and results are reported in RPP-RPT-51020, Rev. 1, Ultrasonic Inspection Results for Double-Shell Tank 241AZ-102- FY2012.

\subsection{PREVIOUS INTEGRITY ASSESSMENTS}

Previous assessments for tanks AZ-101 and AZ-102 include routine UT examinations of the primary tank and annulus and in-tank visual inspections. These routine inspections did not identify any conditions requiring follow up.

\subsection{ANNULUS DESCRIPTION}

The tank annulus is formed by the difference between the 75 feet diameter primary tank and the 80 feet diameter secondary liner resulting in a nominal $2 \frac{1}{2}$ foot wide annular space wrapping around the entire circumference of the primary tank. Several penetrations exist in the top of the secondary liner, which allow access into the annulus space. This access is used for a variety of activities, including visual inspection cameras, sampling, ultrasonic testing crawlers, and leak detection instruments. Access into the annulus space provides visibility of the primary tank wall, secondary liner wall, outer perimeter of the refractory, refractory stiffener ring, ventilation piping, refractory slots, and installed equipment. Figure 1-3 and Figure 1-4 identify some of the features of the annulus of DSTs. 


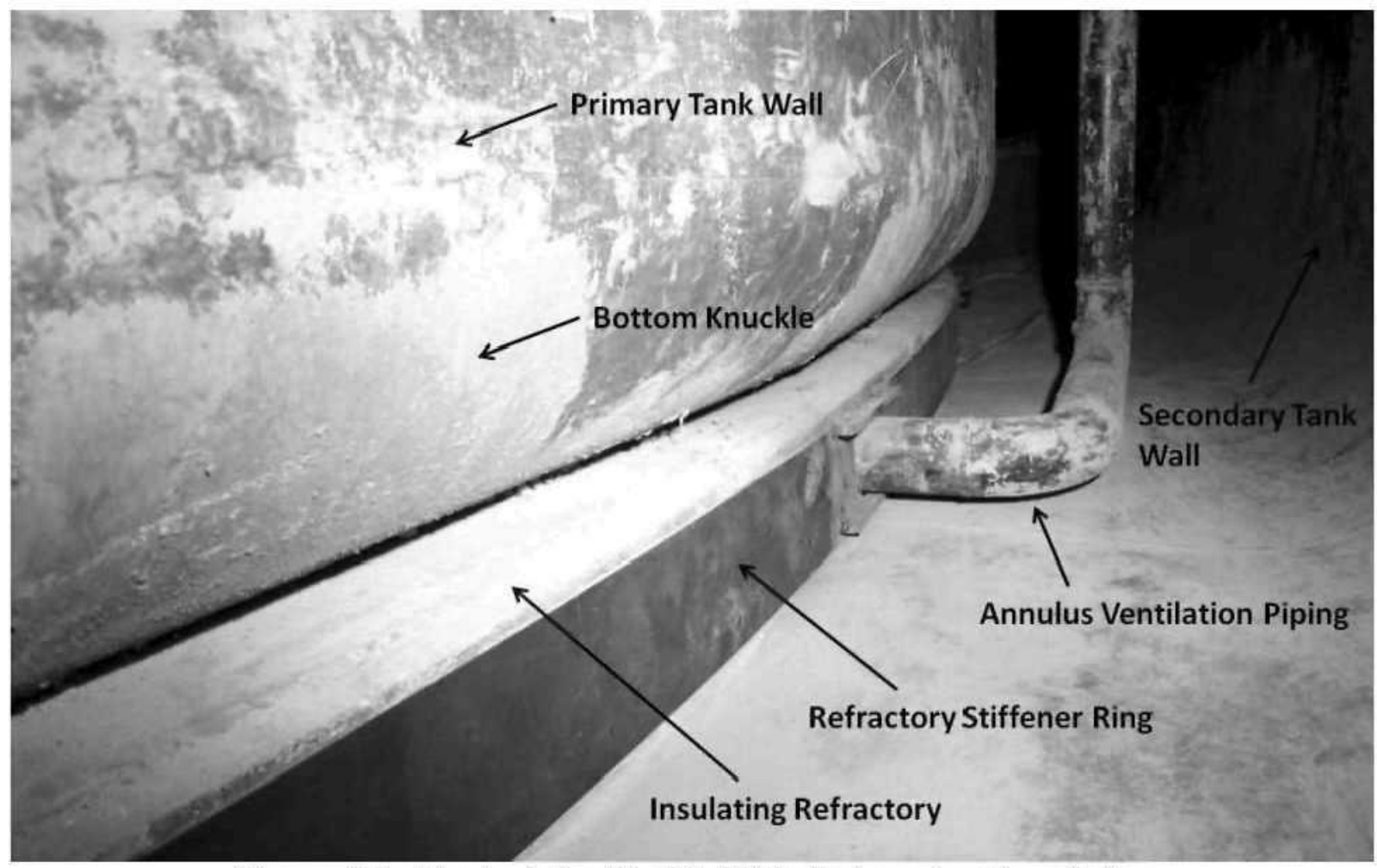

Figure 1-3. Typical Double-Shell Tank Annulus Description

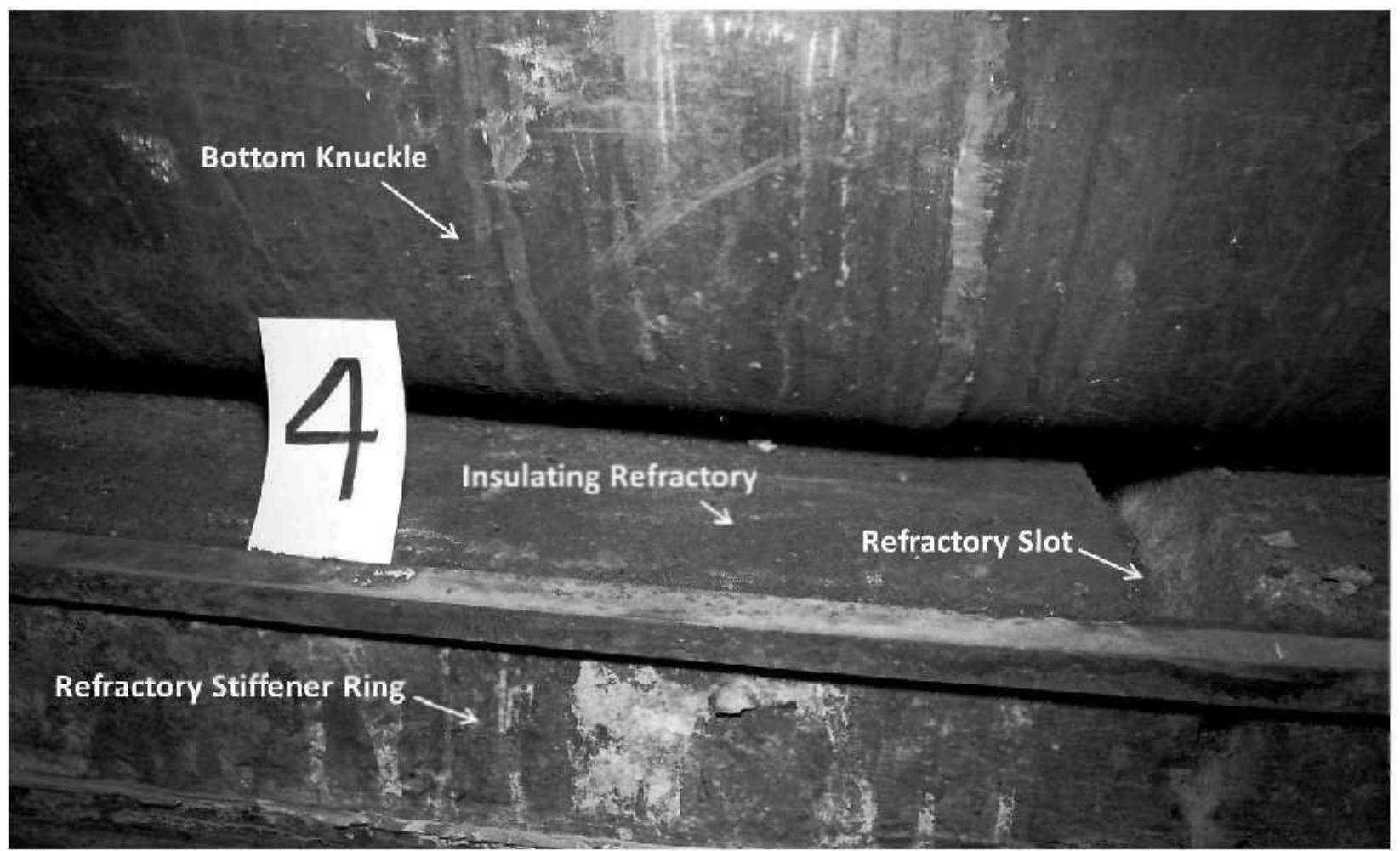

Figure 1-4. 241-AZ Farm Tank Annulus Description Showing Refractory Slot (N1641598) 


\subsection{TANK AZ-101 BASELINE VIDEO INSPECTIONS}

Results of the previous 241-AZ Farm visual inspections are documented in RPP-RPT-34310, Rev. 0, Double-Shell Tank Integrity Inspection Report for 241-AZ Tank Farm. The evaluation factors that make up the inspection criteria for the annulus visual inspections are documented in RPP-PLAN-46847, Rev. 0, Visual Inspection Plan for Single-Shell Tanks and Double-Shell Tanks. In January 2013, visual inspections were performed in eleven risers for tank AZ-101 to provide a baseline inspection, covering $>95 \%$ of annulus floor area, and the portion of the primary tank (i.e., dome, sidewall, lower knuckle, and insulating refractory) that is visible from the annulus inspection risers. Photographs of the general condition of the upper haunch of the primary tank, the bottom knuckle, insulating refractory, refractory slots, stiffener ring, and annulus floor are included in the following subsections with any areas of interest identified. A statement of the general condition of the primary tank sidewall as seen through each riser is included as well as any anomalies; in addition, the general condition of the sidewall will be noted and included in the update to document RPP-RPT-34310, Rev. 0.

The following sections contain screen shots taken of the 2013 baseline inspection performed in designated risers shown in Figure ES-1. In the cases where there are no areas of interest, then a review of the oldest inspection was used for comparisons. However, if anomalies are noted then all previous inspection videos were reviewed to identify any possible changes in the condition of the area of interest.

\subsection{TANK AZ-101 ANNULUS RISER INSPECTIONS}

The tank AZ-101 annulus video inspection risers locations are shown in Figure ES-1. Table 2-1 lists the years of previous inspections and the risers utilized for the 2013 baseline inspections.

Table 2-1. Tank AZ-101 Annulus Riser Visual Inspections

\begin{tabular}{|c|c|c|}
\hline \multicolumn{3}{|c|}{1993} \\
\hline $\begin{array}{c}\text { Riser } \\
\text { Number }\end{array}$ & $\begin{array}{c}\text { Date of } \\
\text { Inspection }\end{array}$ & $\begin{array}{c}\text { DVDID } \\
\text { Number }\end{array}$ \\
\hline $78(17 \mathrm{~A})$ & $07 / 23 / 1993$ & $\begin{array}{c}10400 \\
11023\end{array}$ \\
\hline $79(17 \mathrm{~B})$ & $07 / 22 / 1993$ & 10402 \\
\hline $83(17 \mathrm{~F})$ & $07 / 26 / 1993$ & 10401 \\
\hline
\end{tabular}

\begin{tabular}{|c|c|c|}
\hline \multicolumn{3}{|c|}{$\mathbf{2 0 0 7}$} \\
\hline $\begin{array}{c}\text { Riser } \\
\text { Number }\end{array}$ & $\begin{array}{c}\text { Date of } \\
\text { Inspection }\end{array}$ & $\begin{array}{c}\text { DVDID } \\
\text { Number }\end{array}$ \\
\hline 78 & $06 / 07 / 2007$ & 11145 \\
\hline 82 & $06 / 06 / 2007$ & 11124 \\
\hline 83 & $06 / 06 / 2007$ & 11124 \\
\hline 86 & $06 / 07 / 2007$ & 11143 \\
\hline
\end{tabular}

\begin{tabular}{|c|c|c|}
\hline \multicolumn{3}{|c|}{$\mathbf{2 0 1 3}$} \\
\hline $\begin{array}{c}\text { Riser } \\
\text { Number }\end{array}$ & $\begin{array}{c}\text { Date of } \\
\text { Inspection }\end{array}$ & $\begin{array}{c}\text { DVDID } \\
\text { Number }\end{array}$ \\
\hline 78 & $01 / 09 / 2013$ & 11593 \\
\hline 79 & $01 / 14 / 2013$ & 11594 \\
\hline 81 & $01 / 13 / 2013$ & 11595 \\
\hline 82 & $01 / 11 / 2013$ & 11596 \\
\hline 83 & $01 / 10 / 2013$ & 11597 \\
\hline 84 & $01 / 14 / 2013$ & 11598 \\
\hline 86 & $01 / 07 / 2013$ & 11599 \\
\hline 88 & $01 / 09 / 2013$ & 11600 \\
\hline 89 & $01 / 10 / 2013$ & 11601 \\
\hline 91 & $01 / 15 / 2013$ & 11602 \\
\hline 92 & $01 / 08 / 2013$ & 11603 \\
\hline
\end{tabular}

\begin{tabular}{|c|c|c|}
\hline \multicolumn{3}{|c|}{$\mathbf{2 0 0 1}$} \\
\hline $\begin{array}{c}\text { Riser } \\
\text { Number }\end{array}$ & $\begin{array}{c}\text { Date of } \\
\text { Inspection }\end{array}$ & $\begin{array}{c}\text { DVDID } \\
\text { Number }\end{array}$ \\
\hline 78 & $09 / 25 / 2001$ & 10873 \\
\hline 82 & $09 / 25 / 2001$ & 10404 \\
\hline 83 & $09 / 25 / 2001$ & 10871 \\
\hline 86 & $09 / 25 / 2001$ & 10405 \\
\hline
\end{tabular}

\begin{tabular}{|c|c|c|}
\hline \multicolumn{3}{|c|}{$\mathbf{2 0 0 8}$} \\
\hline $\begin{array}{c}\text { Riser } \\
\text { Number }\end{array}$ & $\begin{array}{c}\text { Date of } \\
\text { Inspection }\end{array}$ & $\begin{array}{c}\text { DVDID } \\
\text { Number }\end{array}$ \\
\hline 78 & $12 / 04 / 2008$ & 11448 \\
\hline 82 & $12 / 03 / 2008$ & 11449 \\
\hline 83 & $12 / 04 / 2008$ & 11450 \\
\hline 86 & $12 / 04 / 2008$ & 11451 \\
\hline
\end{tabular}

Note: Risers 89 and 90 were utilized for previous UT examinations 


\subsection{TANK AZ-101 2013 BASELINE INSPECTION RESULTS AND COMPARISONS TO PREVIOUS INSPECTIONS}

\subsubsection{Tank AZ-101 Riser 78}

Visual inspections performed through Riser 78 in 1993, 2001, and 2013 were compared and results are presented below.

\section{Tank Dome and Upper Haunch - Riser 78}

The tank dome and upper haunch area were not visible during the 1993 inspection. Figure 2-1 and Figure 2-2 show comparisons of the upper haunch area between inspections performed in 2001 and 2013. Since the camera was lower in the 2001 inspection, it is difficult to make any comparisons with the 2013 inspection of the top knuckle area. However, there appears to be no significant changes in the condition of this area from 2001 to 2013. No areas of interest were identified in the top knuckle region during the 2013 inspection.

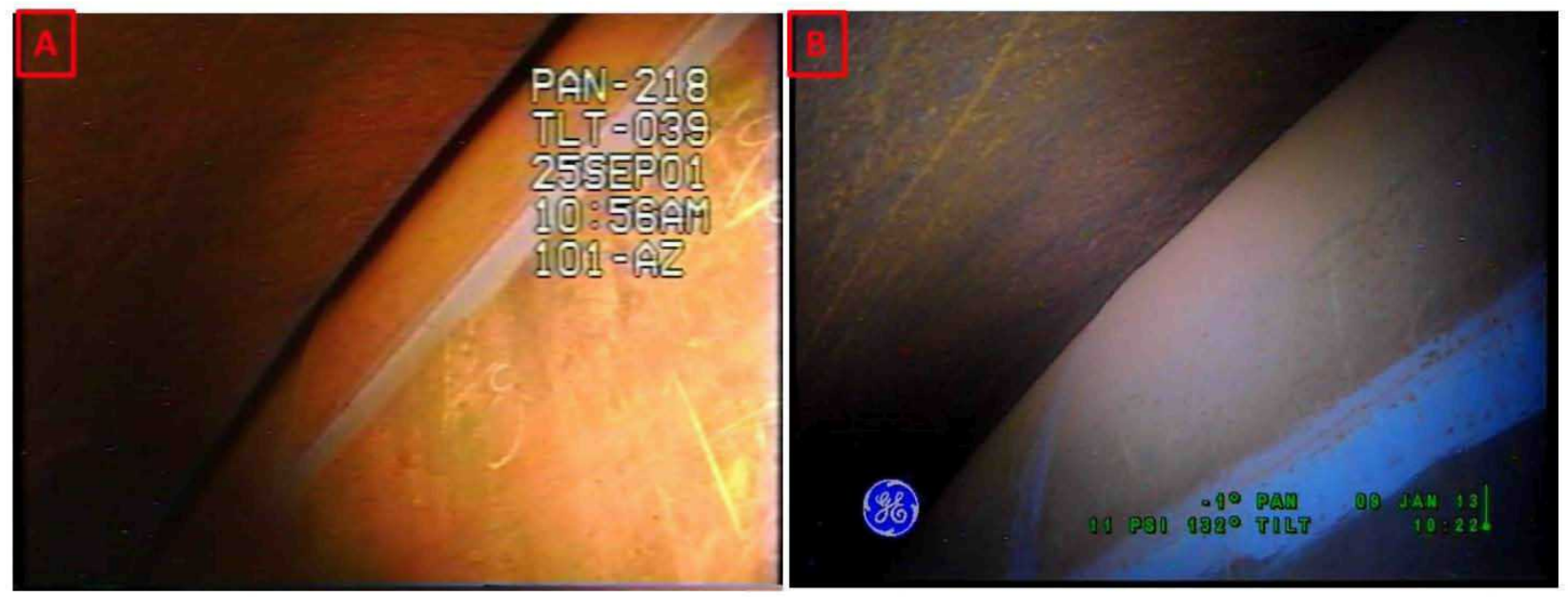

Figure 2-1. Riser 78 Upper Haunch Comparisons Between Inspections on September 25, 2001 (A) and January 9, 2013 (B) Looking Towards Riser 93 


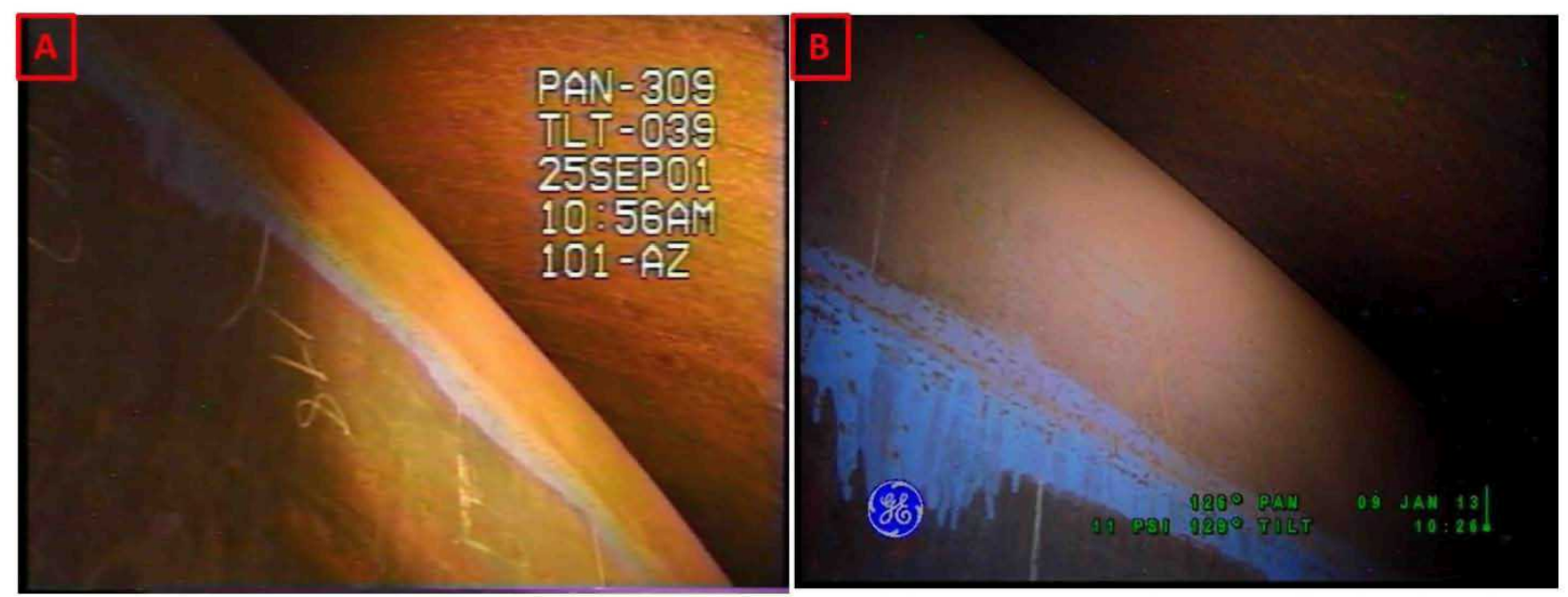

Figure 2-2. Riser 78 Upper Haunch Comparisons Between Inspections on September 25, 2001 (A) and January 9, 2013 (B) Looking Towards Riser 90

\section{Sidewall Comparison - Riser 78}

The sidewall of the primary tank appears to be in good condition and no areas of interest were identified on the primary tank sidewall during the 2013 inspection.

\section{Lower Knuckle and Annulus Floor Comparisons - Riser 78}

Figure 2-3 and Figure 2-4 show comparisons of the lower knuckle and annulus floor between inspections performed in 2001 and 2013. There appears to be no significant change in the condition of this area between 1993 and 2013. A beachline can also be seen along the annulus floor in Figure 2-3 and Figure 2-4 which is likely the result of evaporated couplant water used during UT examinations. Figure 2-5 shows the general condition of the refractory slots in 2013 and no anomalies were noted. No anomalies were identified on the lower knuckle of the primary tank, insulating refractory, refractory slots, stiffener ring, or annulus floor during the 2013 inspection.
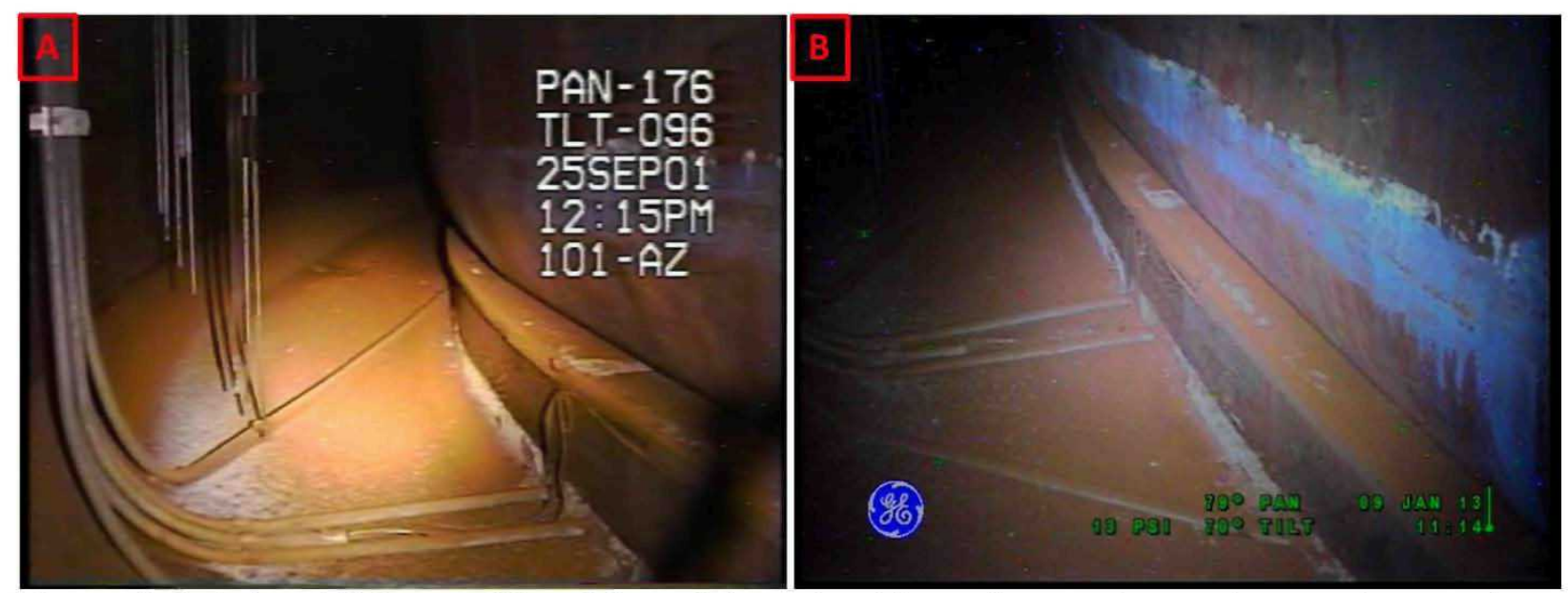

Figure 2-3. Riser 78 Lower Knuckle and Annulus Floor Comparisons Between Inspections on September 25, 2001 (A) and January 9, 2013 (B) Looking Towards Riser 93 

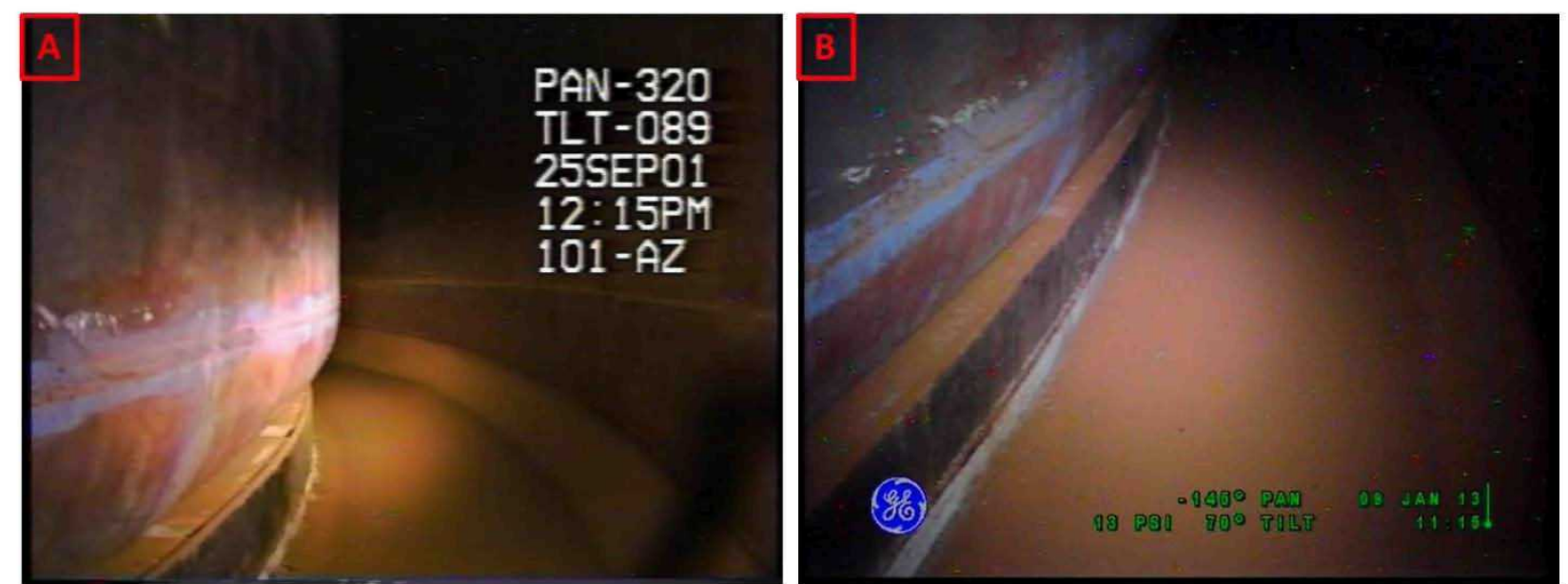

Figure 2-4. Riser 78 Lower Knuckle and Annulus Floor Comparisons Between Inspections on September 25, 2001 (A) and January 9, 2013 (B) Looking Towards Riser 90
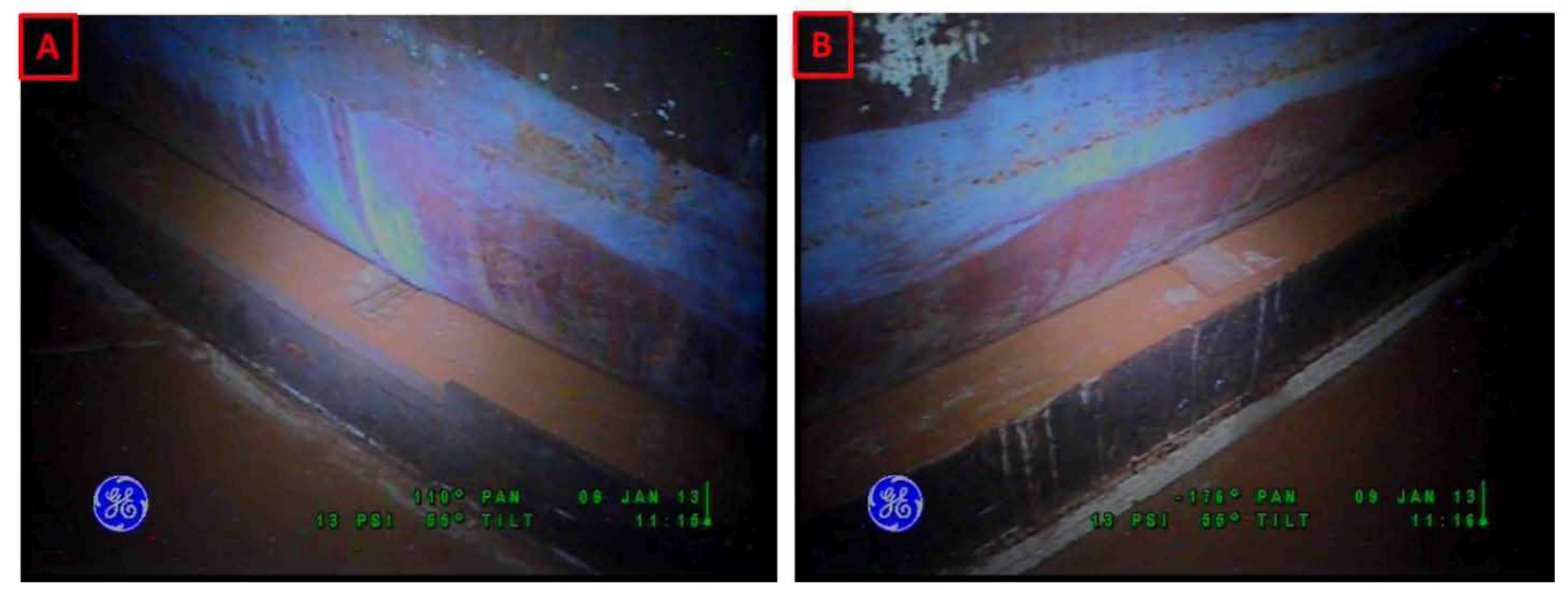

Figure 2-5. Riser 78 General Condition of the Refractory Slots on January 9, 2013

\subsubsection{Tank AZ-101 Riser 79}

Visual inspection results performed through Riser 79 in 1993 and 2013 were compared and results are presented below.

\section{Tank Dome and Upper Haunch - Riser 79}

Figure 2-6 and Figure 2-7 show comparisons of the upper haunch area between inspections performed in 2001 and 2013. In both of these figures, white streaks can be seen on the primary tank. These white streaks, which are commonly seen among the DSTs, are referred to as laitance flow attributed to the pouring of the concrete dome during construction. There were no significant changes in the condition of this area from 2001 to 2013 . No areas of interest were identified in the top knuckle region during the 2013 inspection. 

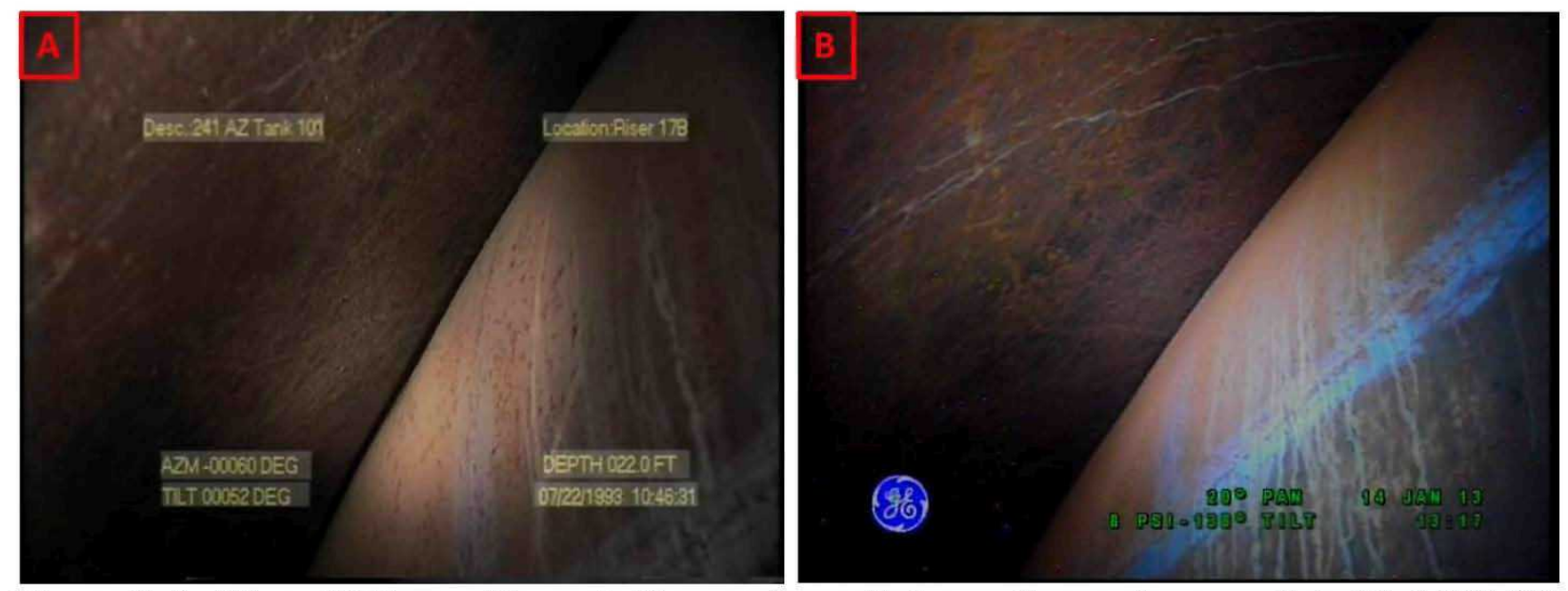

Figure 2-6. Riser 79 Upper Haunch Comparisons Between Inspections on July 22, 1993 (A) and January 14, 2013 (B) Looking Towards Riser 80

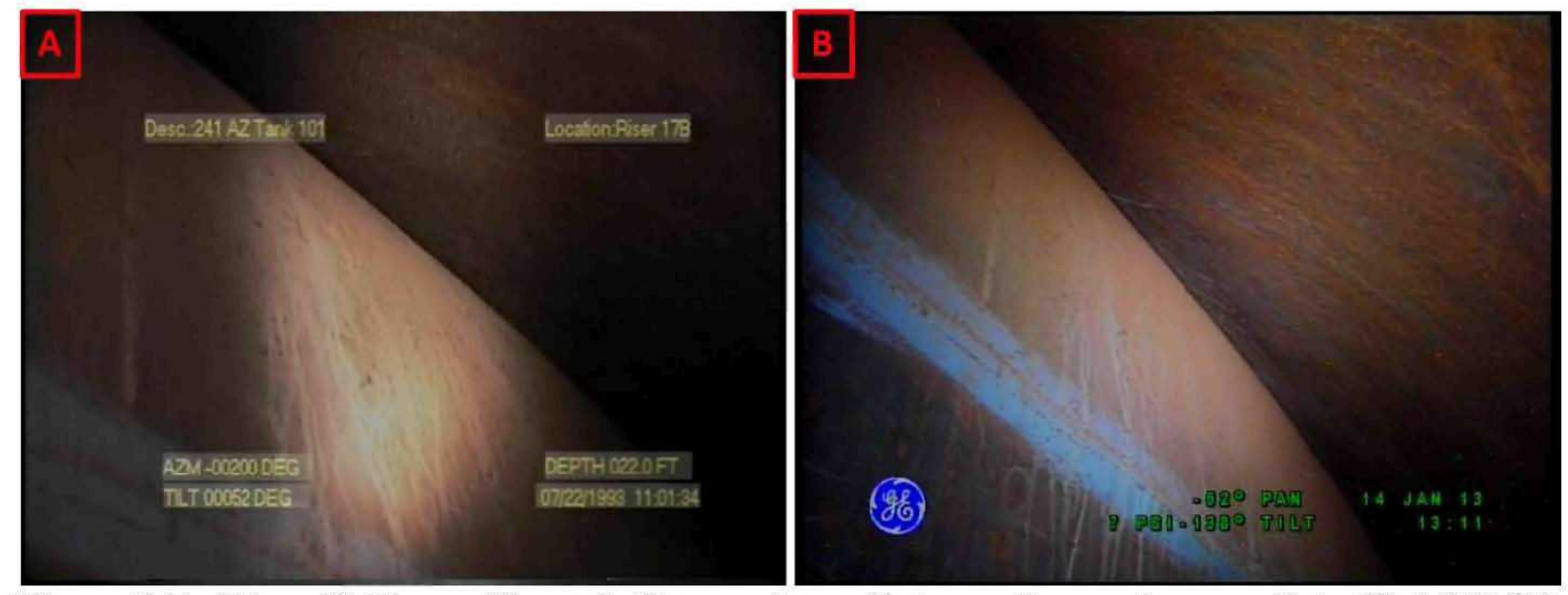

Figure 2-7. Riser 79 Upper Haunch Comparisons Between Inspections on July 22, 1993 (A) and January 14, 2013 (B) Looking Towards Riser 99

\section{Sidewall Comparison - Riser 79}

The sidewall of the primary tank appears to be in good condition and no areas of interest were identified on the primary tank sidewall during the 2013 inspection.

\section{Lower Knuckle and Annulus Floor Comparisons - Riser 79}

The lower knuckle and annulus floor were not visible during the 1993 inspection. Figure 2-8 shows the general condition of the lower knuckle and annulus floor in 2013. A beachline can be seen along the annulus floor in Figure 2-8 which is likely the result of evaporated couplant water used during UT examinations. Figure 2-9 shows the general condition of the refractory slots in 2013 and no anomalies were noted. No anomalies were identified on the lower knuckle of the primary tank, insulating refractory, refractory slots, stiffener ring, or annulus floor during the 2013 inspection. 


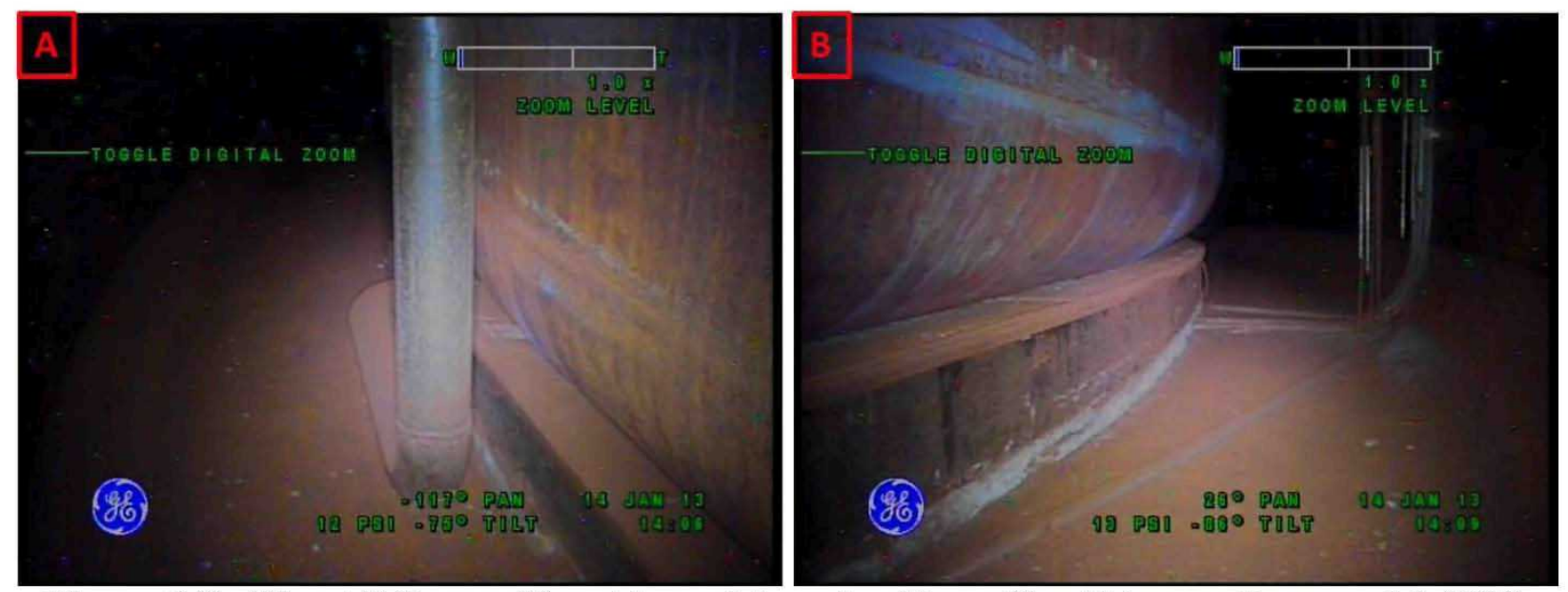

Figure 2-8. Riser 79 Lower Knuckle and Annulus Floor Condition on January 14, 2013 Looking Towards Riser 80 (A) and Looking Towards Riser 99 (B)

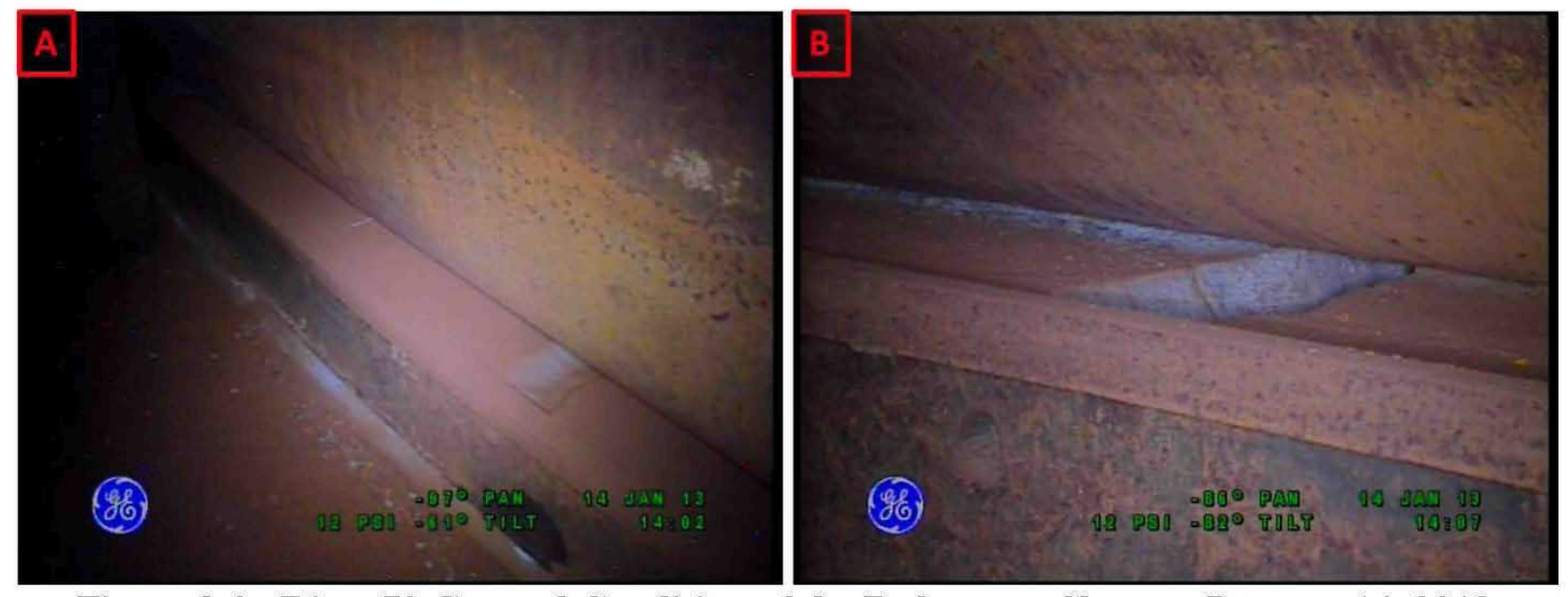

Figure 2-9. Riser 79 General Condition of the Refractory Slots on January 14, 2013

\subsubsection{Tank AZ-101 Riser 81}

Visual inspection results performed through Riser 81 in 2013 are presented below. There were no previous inspections performed through Riser 81 for comparisons.

\section{Tank Dome and Upper Haunch - Riser 81}

Figure 2-10 shows the general condition of the top knuckle area in January 2013. No areas of interest were identified in the top knuckle region during the 2013 inspection. 


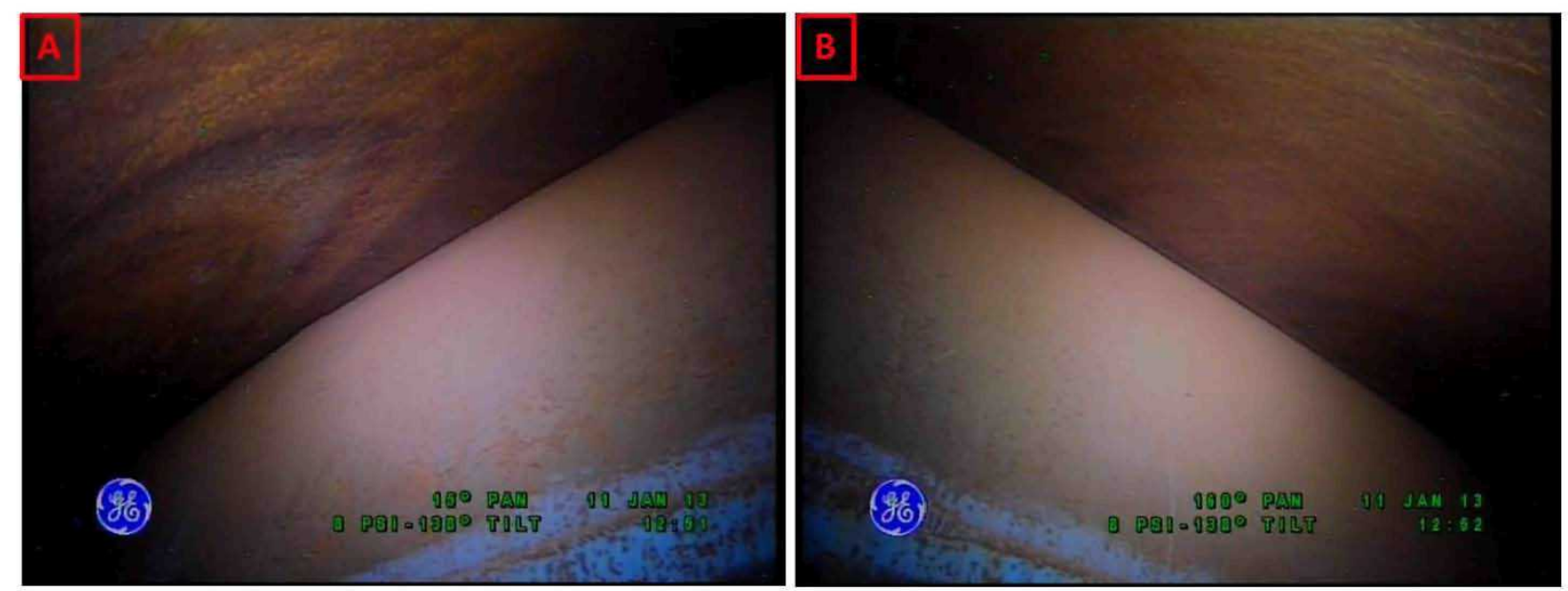

Figure 2-10. Riser 81 Upper Haunch Condition on January 11, 2013 Looking Towards Riser 105 (A) and Looking Towards Riser 100 (B)

\section{Sidewall Comparison - Riser 81}

The sidewall of the primary tank appears to be in good condition and no areas of interest were identified on the primary tank sidewall during the 2013 inspection.

\section{Lower Knuckle and Annulus Floor Comparisons - Riser 81}

Figure 2-11 shows the general condition of the lower knuckle and annulus floor in January 2013. A beachline can also be seen along the annulus floor in Figure 2-11 which is likely the result of evaporated couplant water used during UT examinations. In Figure 2-11A, there appears to be signs of previous intrusion coming from Riser 105, the annulus pump pit. There is currently no pump installed in the AZ-101 annulus pump pit. The debris seen in Figure 2-11A is most likely remnants of past dirt and moisture which migrated into the pit and eventually into the annulus space. Figure 2-12 shows the general condition of the refractory slots in 2013 and no anomalies were noted. No anomalies were identified on the lower knuckle of the primary tank, insulating refractory, refractory slots, stiffener ring, or annulus floor during the 2013 inspection.
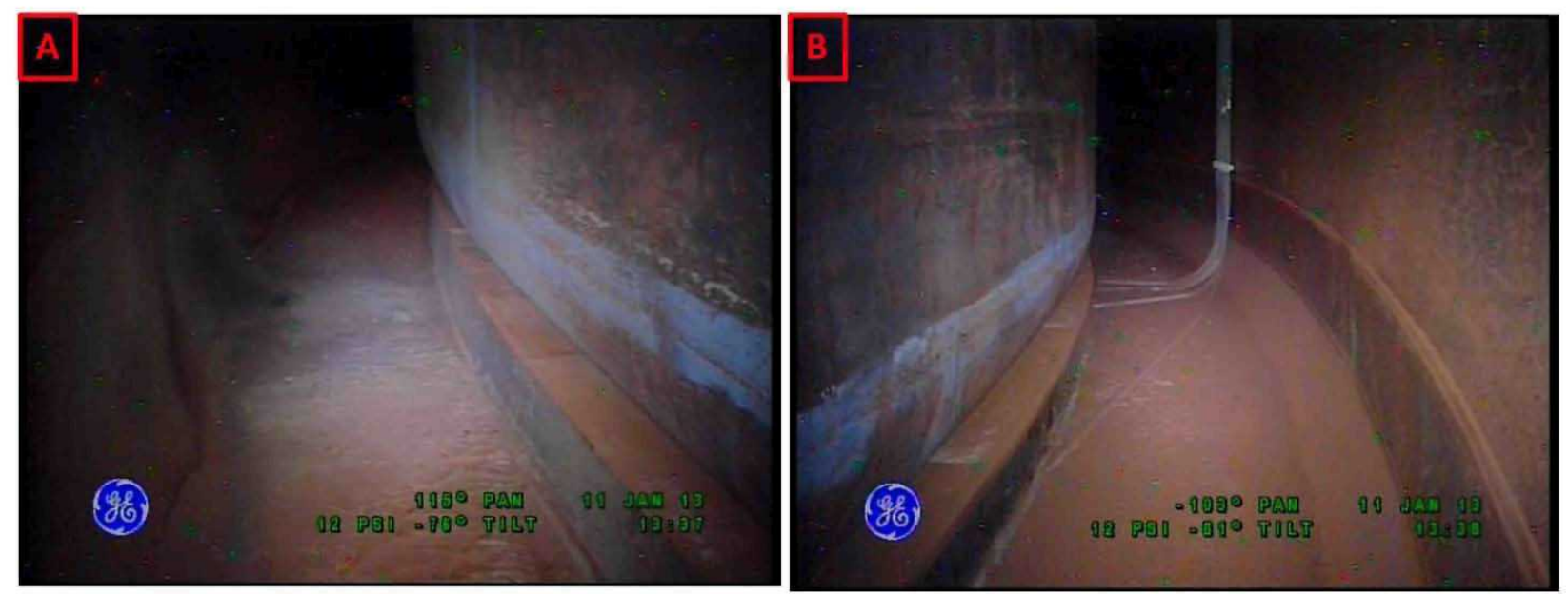

Figure 2-11. Riser 81 Lower Knuckle and Annulus Floor Condition on January 11, 2013 Looking Towards Riser 105 (A) and Looking Towards Riser 100 (B) 


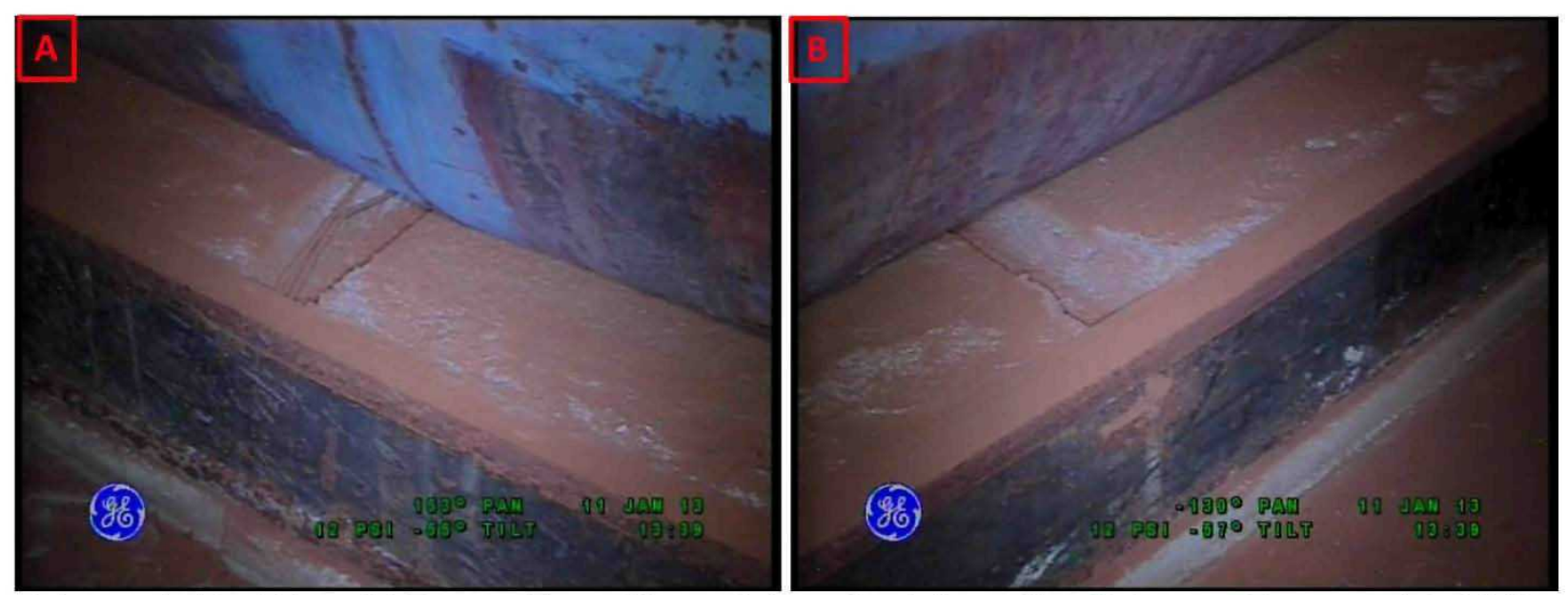

Figure 2-12. Riser 81 Lower Knuckle and Annulus Floor Condition on January 11, 2013

\subsubsection{Tank AZ-101 Riser 82}

Visual inspections performed through Riser 82 in 2001, 2007, 2008, and 2013 were compared and results are presented below.

\section{Tank Dome and Upper Haunch - Riser 82}

The tank dome and upper haunch area were not visible during the 2001 and 2007 inspections. Figure 2-13 and Figure 2-14 show comparisons of the upper haunch area between inspections performed in 2008 and 2013. There were no significant changes in the condition of this area from 2008 to 2013. No areas of interest were identified in the top knuckle region during the 2013 inspection.

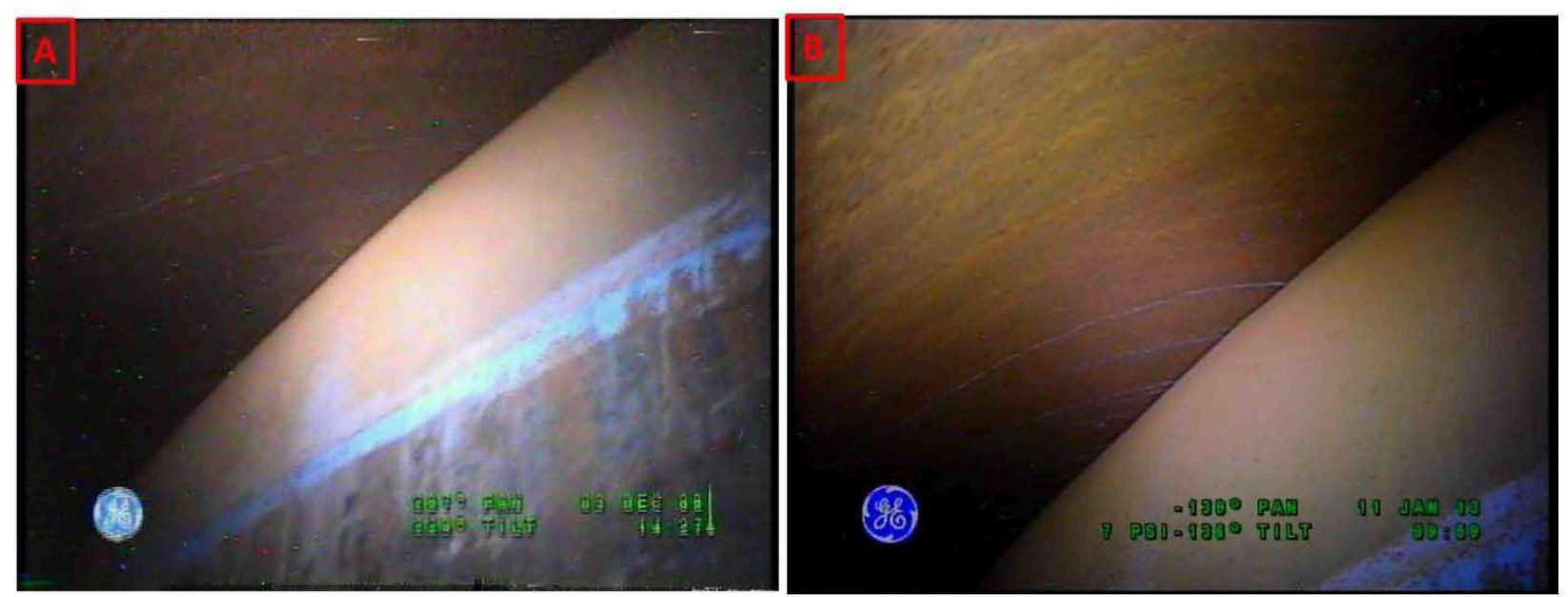

Figure 2-13. Riser 82 Upper Haunch Comparisons Between Inspections on December 3, 2008 (A) and January 11, 2013 (B) Looking Towards Riser 95 

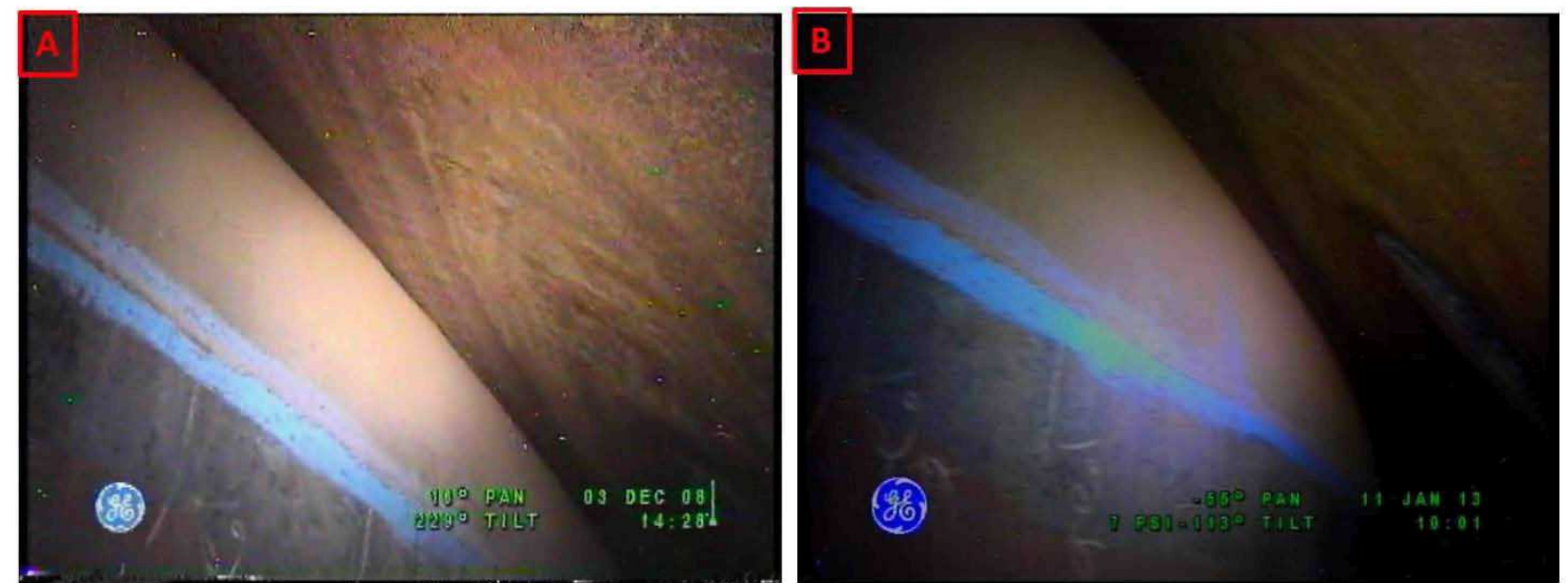

Figure 2-14. Riser 82 Upper Haunch Comparisons Between Inspections on December 3, 2008 (A) and January 11, 2013 (B) Looking Towards Riser 105

\section{Sidewall Comparison - Riser 82}

The sidewall of the primary tank appears to be in good condition and no areas of interest were identified on the primary tank sidewall during the 2013 inspection.

\section{Lower Knuckle and Annulus Floor Comparisons - Riser 82}

Figure 2-15 and Figure 2-16 show comparisons of the lower knuckle and annulus floor between inspections performed in 2001 and 2013. There appears to be no significant change in the condition of this area between 1993 and 2013. Figure 2-17 shows the general condition of the refractory slots in 2013 and no anomalies were noted. No anomalies were identified on the lower knuckle of the primary tank, insulating refractory, refractory slots, stiffener ring, or annulus floor during the 2013 inspection.
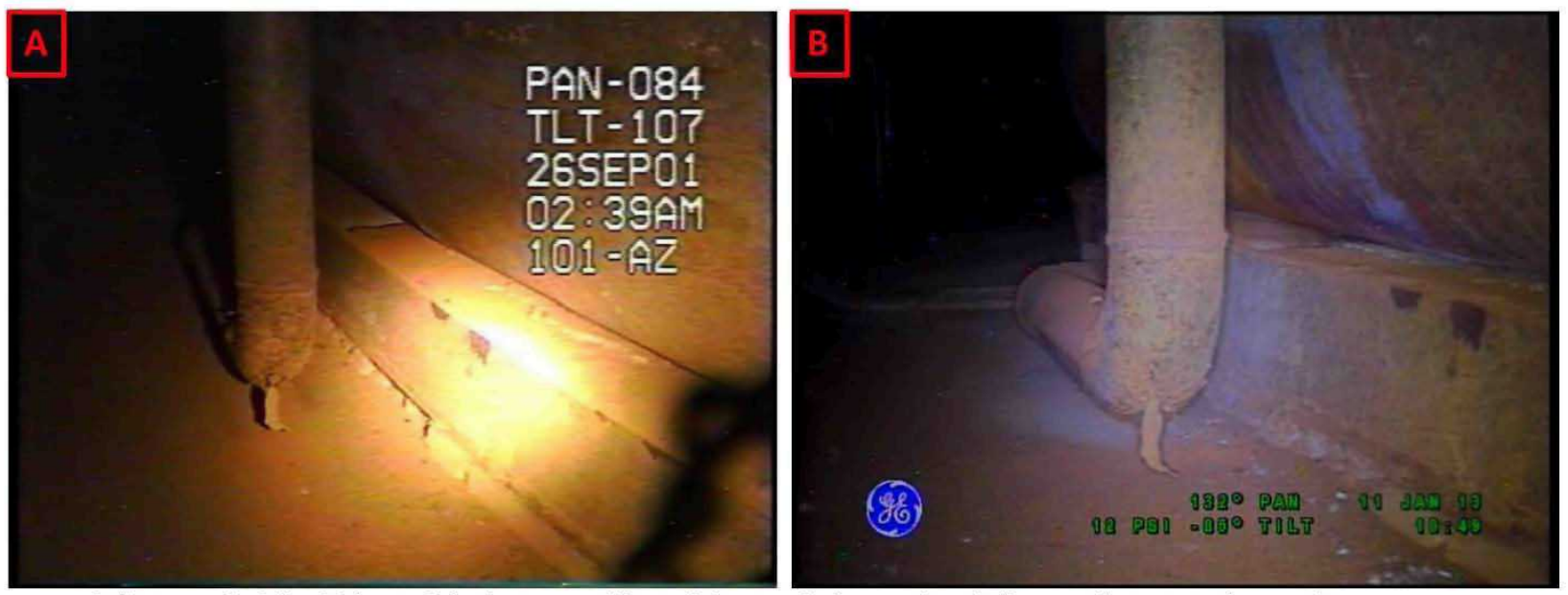

Figure 2-15. Riser 82 Lower Knuckle and Annulus Floor Comparisons Between Inspections on September 26, 2001 (A) and January 11, 2013 (B) Looking Towards Riser 

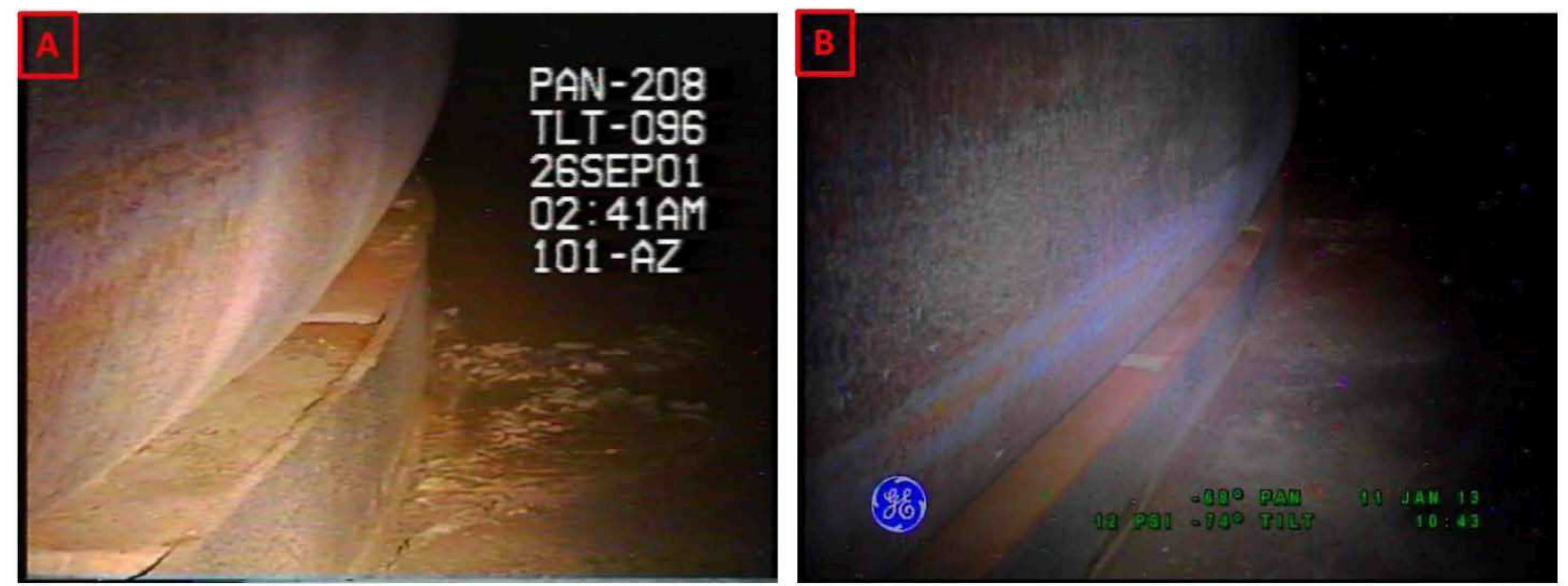

Figure 2-16. Riser 82 Lower Knuckle and Annulus Floor Comparisons Between Inspections on September 26, 2001 (A) and January 11, 2013 (B) Looking Towards Riser 105
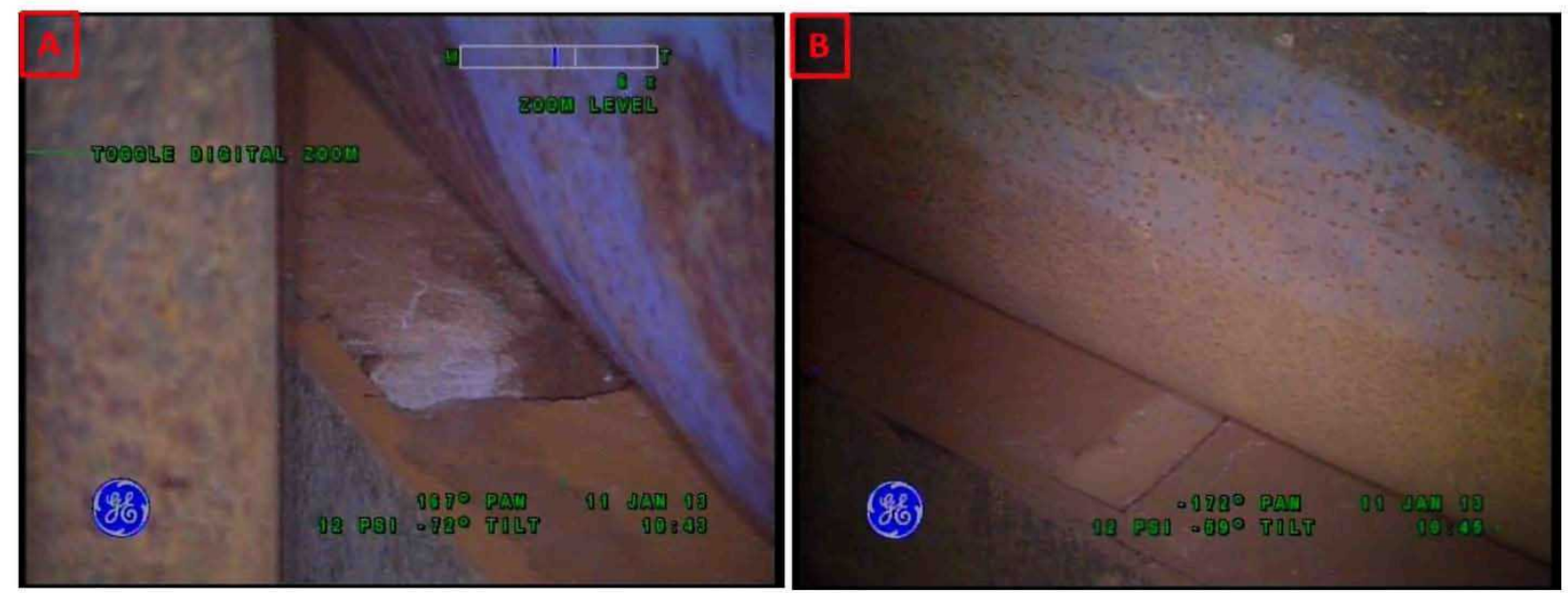

Figure 2-17. Riser 82 General Condition of the Refractory Slots on January 11, 2013

\subsubsection{Tank AZ-101 Riser 83}

Visual inspections performed through Riser 83 in 1993, 2001, and 2013 were compared and results are presented below.

\section{Tank Dome and Upper Haunch - Riser 83}

Figure 2-18 and Figure 2-19 show comparisons of the upper haunch area between inspections performed in 1993 and 2001, respectively, with the 2013 inspection. There were no significant changes in the condition of this area from 1993 or 2001 to 2013. No areas of interest were identified in the top knuckle region during the 2013 inspection. 


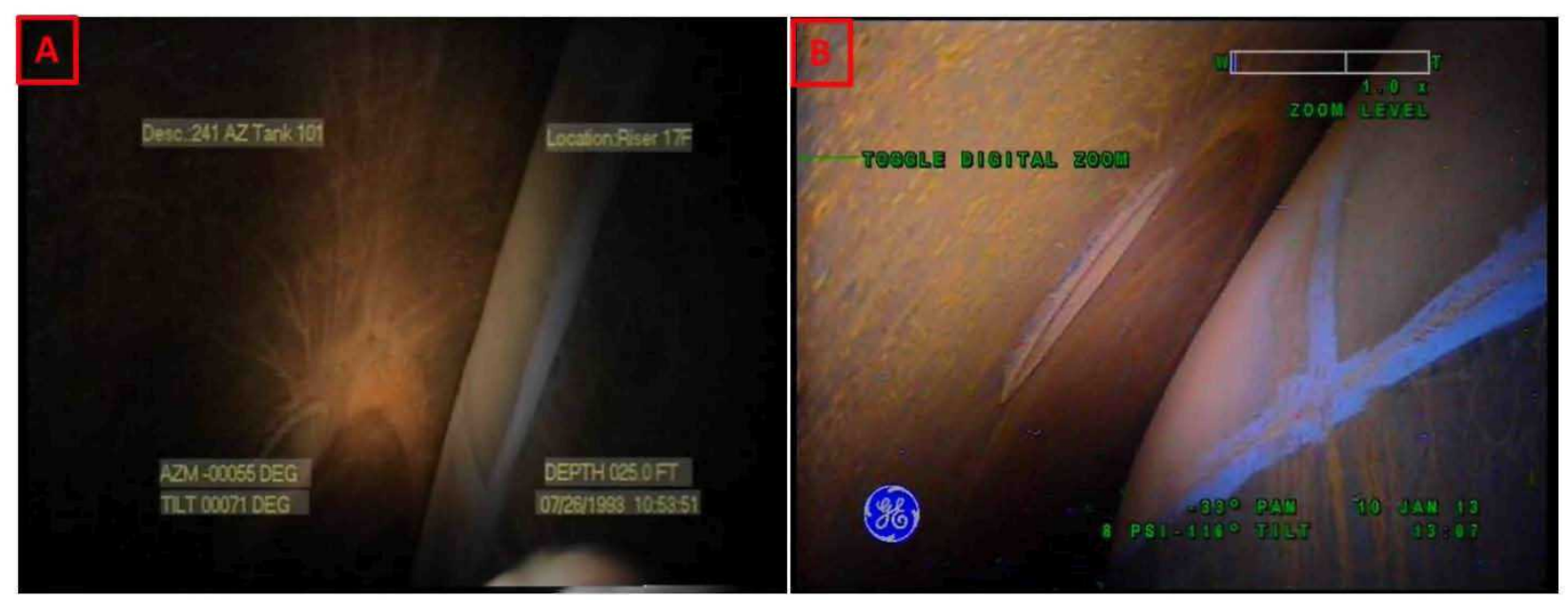

Figure 2-18. Riser 83 Upper Haunch Comparisons Between Inspections on July 26, 1993 (A) and January 10, 2013 (B) Looking Towards Riser 96

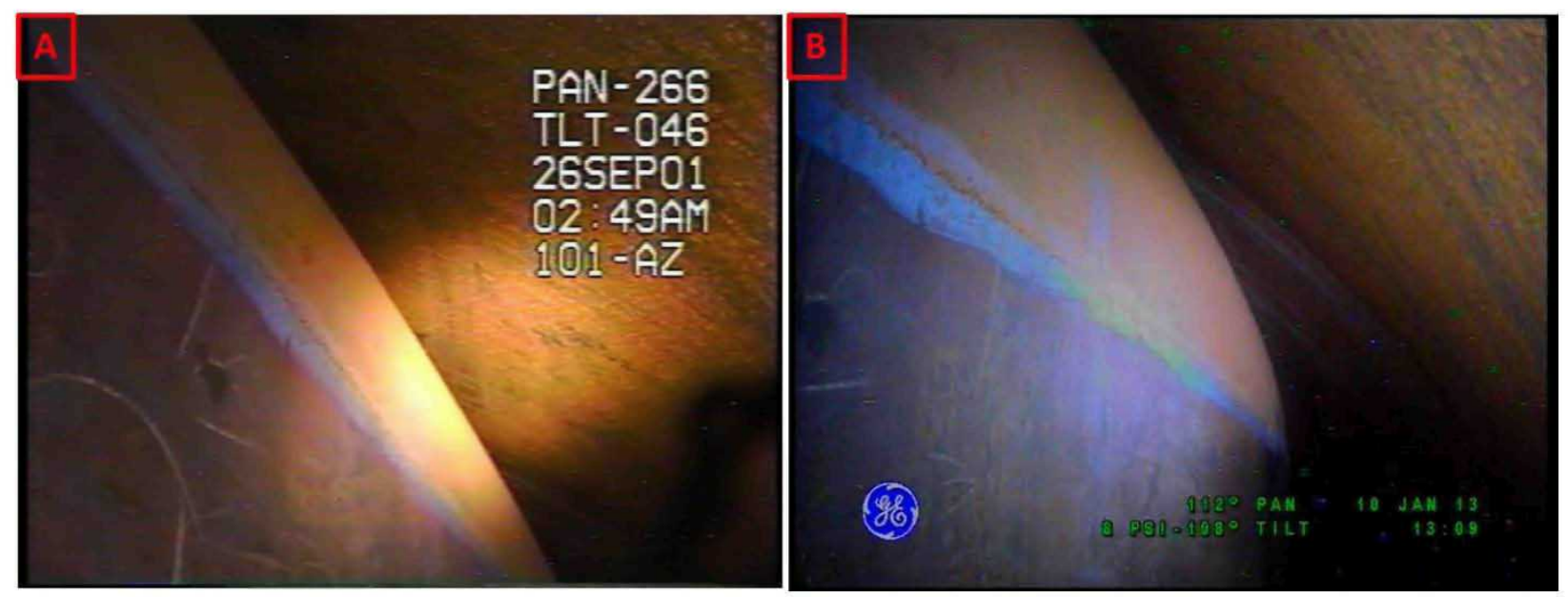

Figure 2-19. Riser 83 Upper Haunch Comparisons Between Inspections on September 26, 2001 (A) and January 10, 2013 (B) Looking Towards Riser 89

\section{Sidewall Comparison - Riser 83}

The sidewall of the primary tank appears to be in good condition and no areas of interest were identified on the primary tank sidewall during the 2013 inspection.

\section{Lower Knuckle and Annulus Floor Comparisons - Riser 83}

Figure 2-20 and Figure 2-21 show comparisons of the lower knuckle and annulus floor between inspections performed in 1993 and 2013. A beachline can also be seen along the annulus floor in Figure 2-20B which is likely the result of evaporated couplant water used during UT examinations. In Figure 2-21B, there appears to be more staining on the annulus floor when compared to the 1993 inspection which is likely the result of evaporated couplant water used in previous UT examinations performed in nearby Riser 89 . There appears to be no significant change in the condition of this area between 1993 and 2013. Figure 2-22 shows the general condition of the refractory slots in 2013 and no anomalies were noted. No anomalies were 
identified on the lower knuckle of the primary tank, insulating refractory, refractory slots, stiffener ring, or annulus floor during the 2013 inspection.
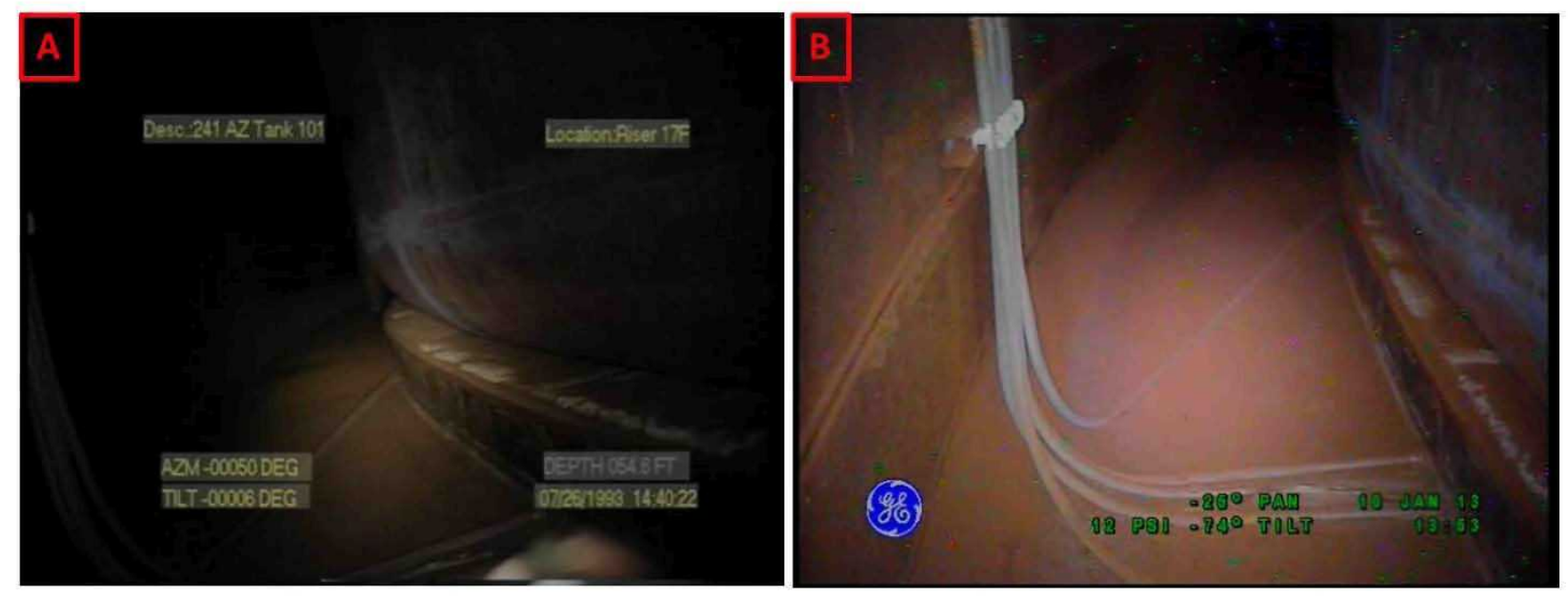

Figure 2-20. Riser 83 Lower Knuckle and Annulus Floor Comparisons Between Inspections on July 26, 1993 (A) and January 10, 2013 (B) Looking Towards Riser 96
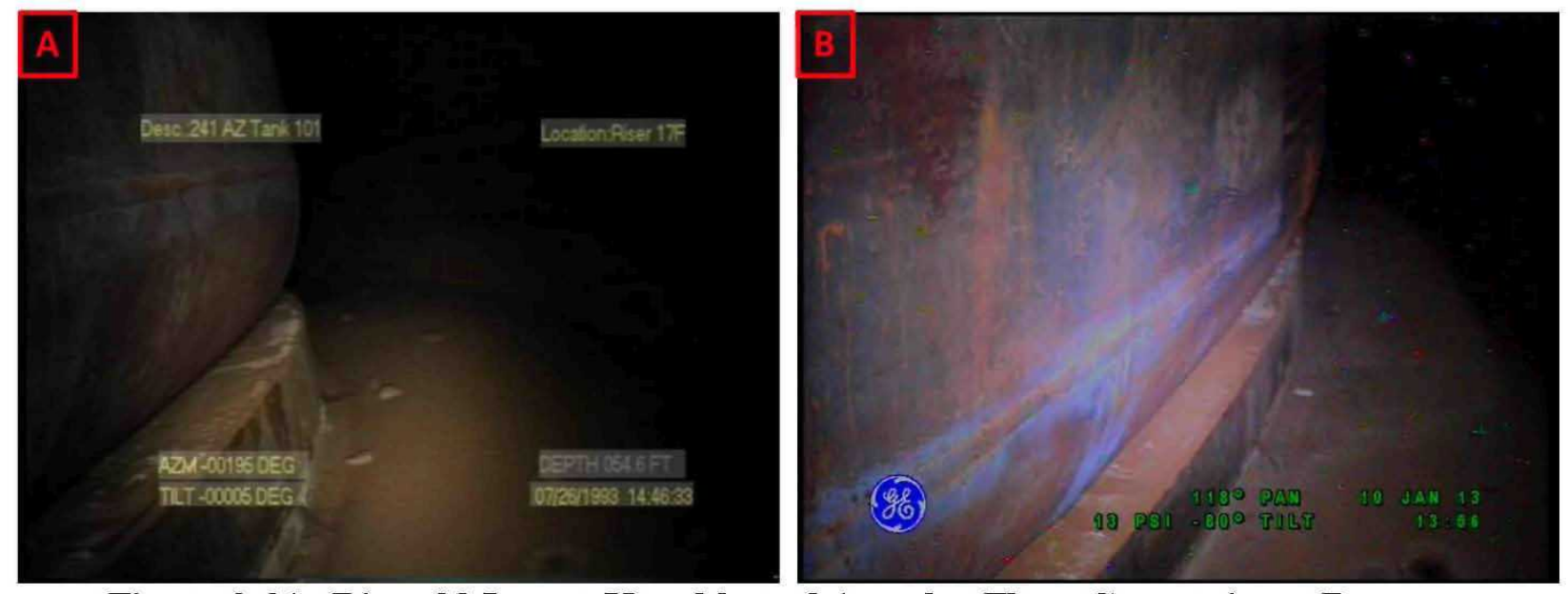

Figure 2-21. Riser 83 Lower Knuckle and Annulus Floor Comparisons Between Inspections on July 26, 1993 (A) and January 10, 2013 (B) Looking Towards Riser 89 


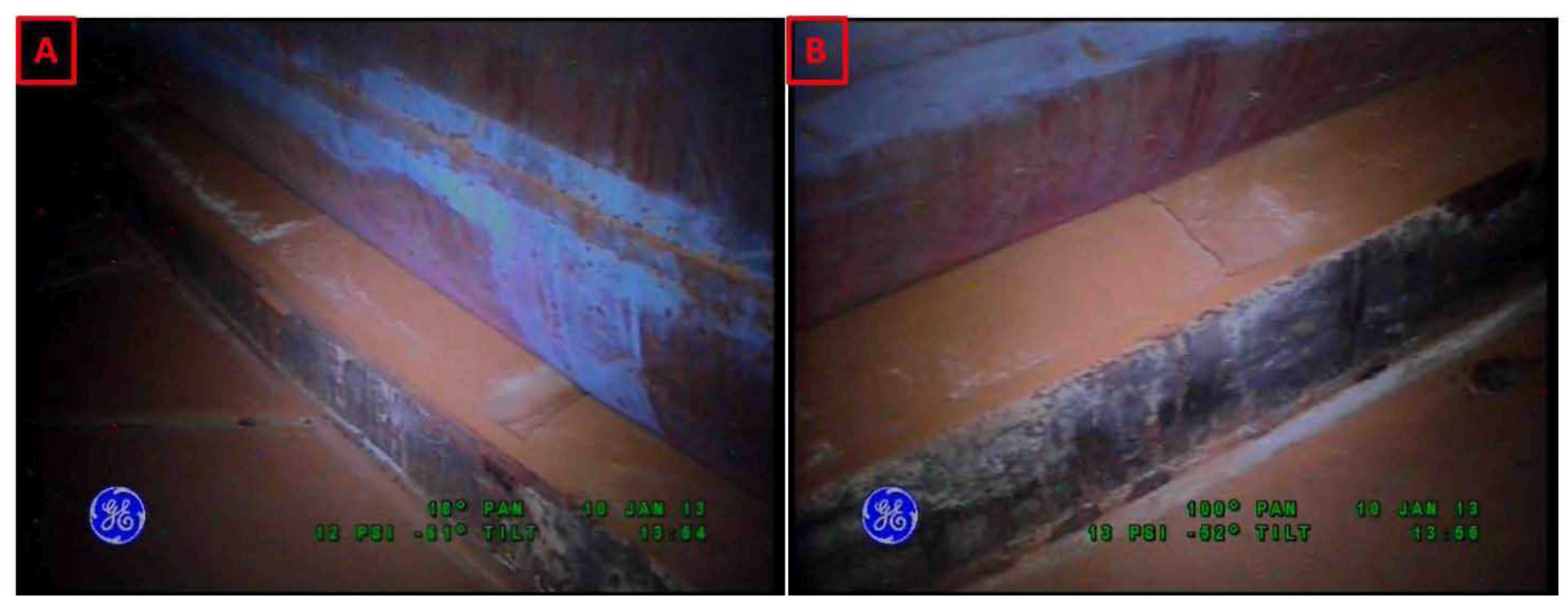

Figure 2-22. Riser 83 General Condition of the Refractory Slots on January 10, 2013

\subsubsection{Tank AZ-101 Riser 84}

Visual inspections results performed through Riser 84 in 2013 are presented below. There were no previous inspections performed through Riser 84 for comparisons.

\section{Tank Dome and Upper Haunch - Riser 84}

Figure 2-23 shows the general condition of the upper haunch area in January 2013. No areas of interest were identified in the top knuckle region during the 2013 inspection.
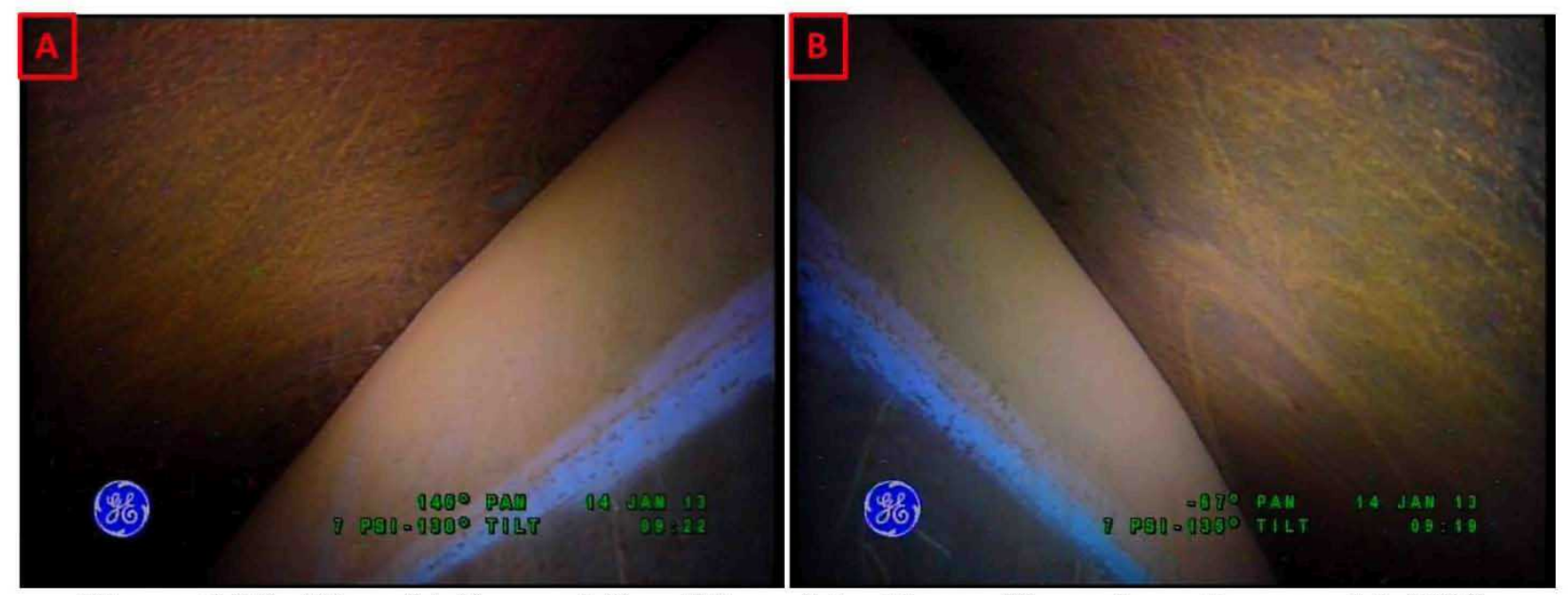

Figure 2-23. Riser 84 General Condition of the Upper Haunch on January 14, 2013 Looking Towards Riser 85 (A) and Looking Towards Riser 102 (B)

\section{Sidewall Comparison - Riser 84}

The sidewall of the primary tank appears to be in good condition and no areas of interest were identified on the primary tank sidewall during the 2013 inspection. 


\section{Lower Knuckle and Annulus Floor Comparisons - Riser 84}

Figure 2-24 shows the general condition of the lower knuckle and annulus floor in January 2013. A beachline can also be seen along the annulus floor in Figure 2-24 which is likely the result of evaporated couplant water used during UT examinations. Figure 2-25 shows the general condition of the refractory slots in January 2013 and no anomalies were noted. No anomalies were identified on the lower knuckle of the primary tank, insulating refractory, refractory slots, stiffener ring, or annulus floor during the 2013 inspection.

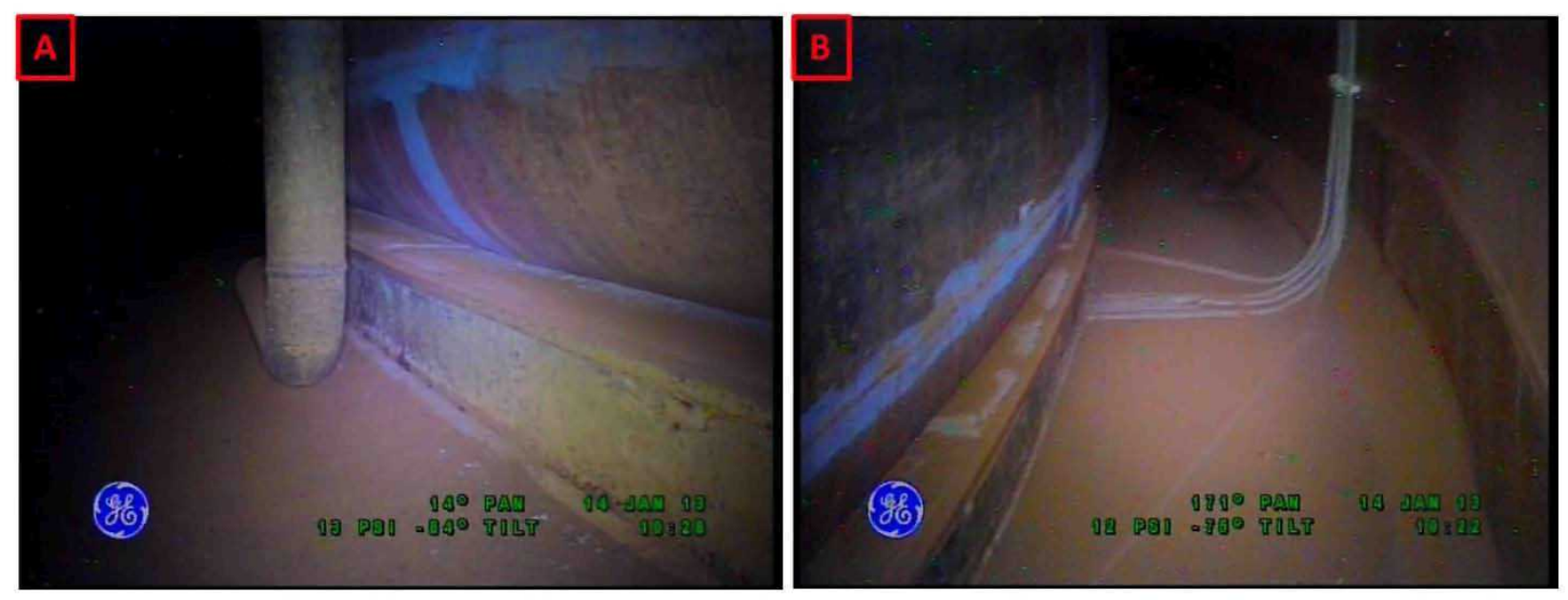

Figure 2-24. Riser 84 Lower Knuckle and Annulus Floor Condition on January 14, 2013 Looking Towards Riser 85 (A) and Looking Towards Riser 102 (B)
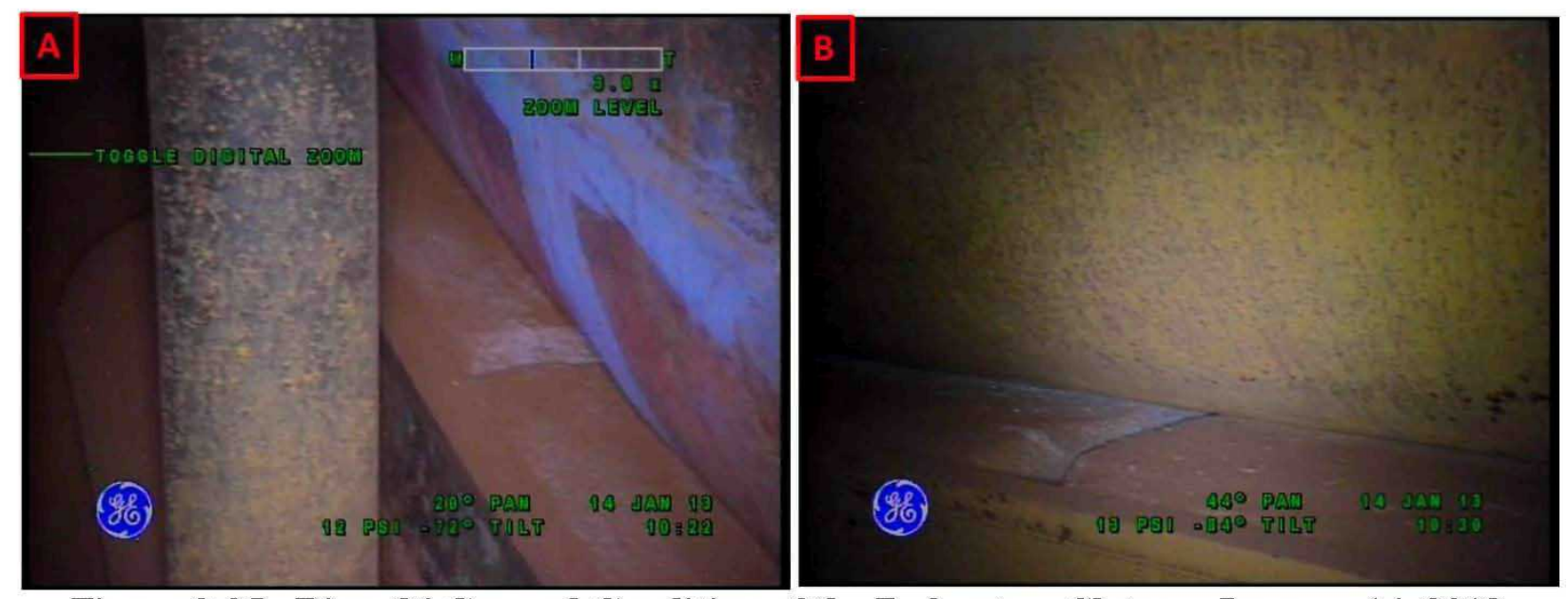

Figure 2-25. Riser 84 General Condition of the Refractory Slots on January 14, 2013

\subsubsection{Tank AZ-101 Riser 86}

Visual inspections performed through Riser 86 in 2001 and 2013 were compared and results are presented below. 


\section{Tank Dome and Upper Haunch - Riser 86}

Figure 2-26 and Figure 2-27 show comparisons of the upper haunch area between inspections performed in 2001 and 2013. In both of these figures, white streaks can be seen on the primary tank and secondary liner. These white streaks, which are commonly seen among the DSTs, are referred to as laitance flow attributed to the pouring of the concrete dome during construction. There were no significant changes in the condition of this area from 2001 to 2013. No areas of interest were identified in the top knuckle region during the 2013 inspection.

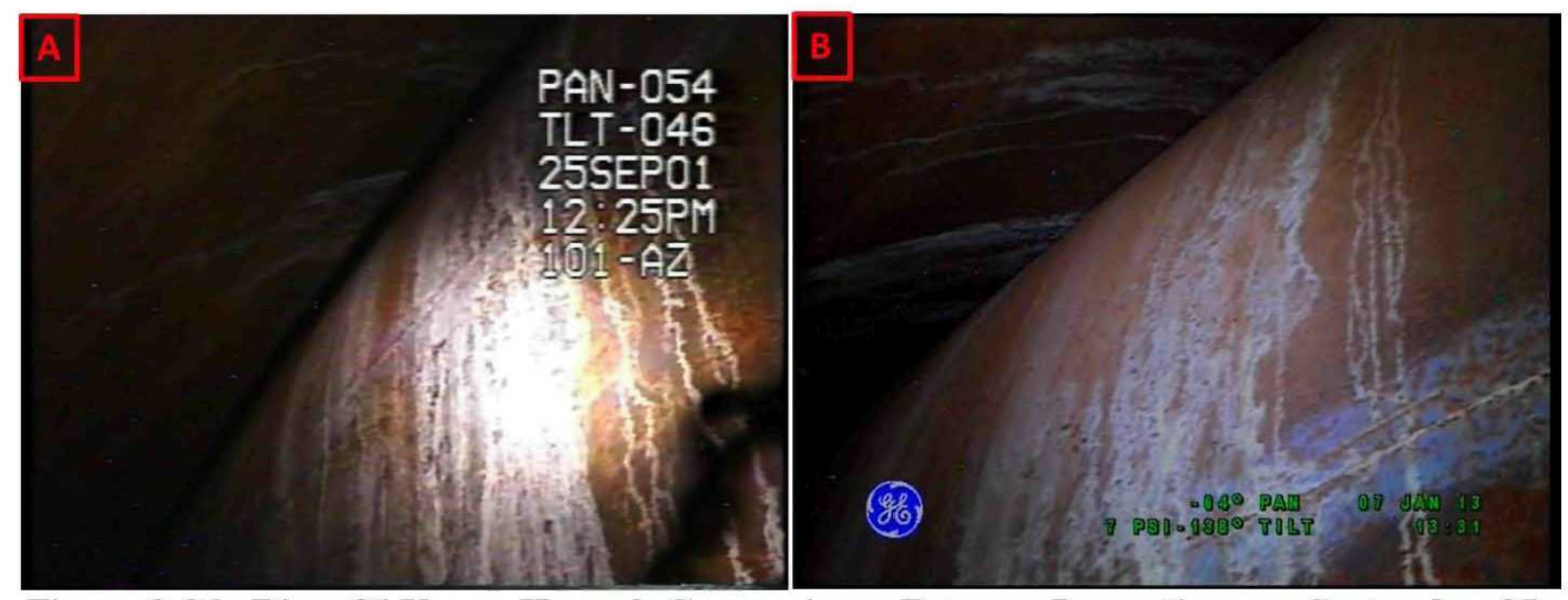

Figure 2-26. Riser 86 Upper Haunch Comparisons Between Inspections on September 25, 2001 (A) and January 7, 2013 (B) Looking Towards Riser 87

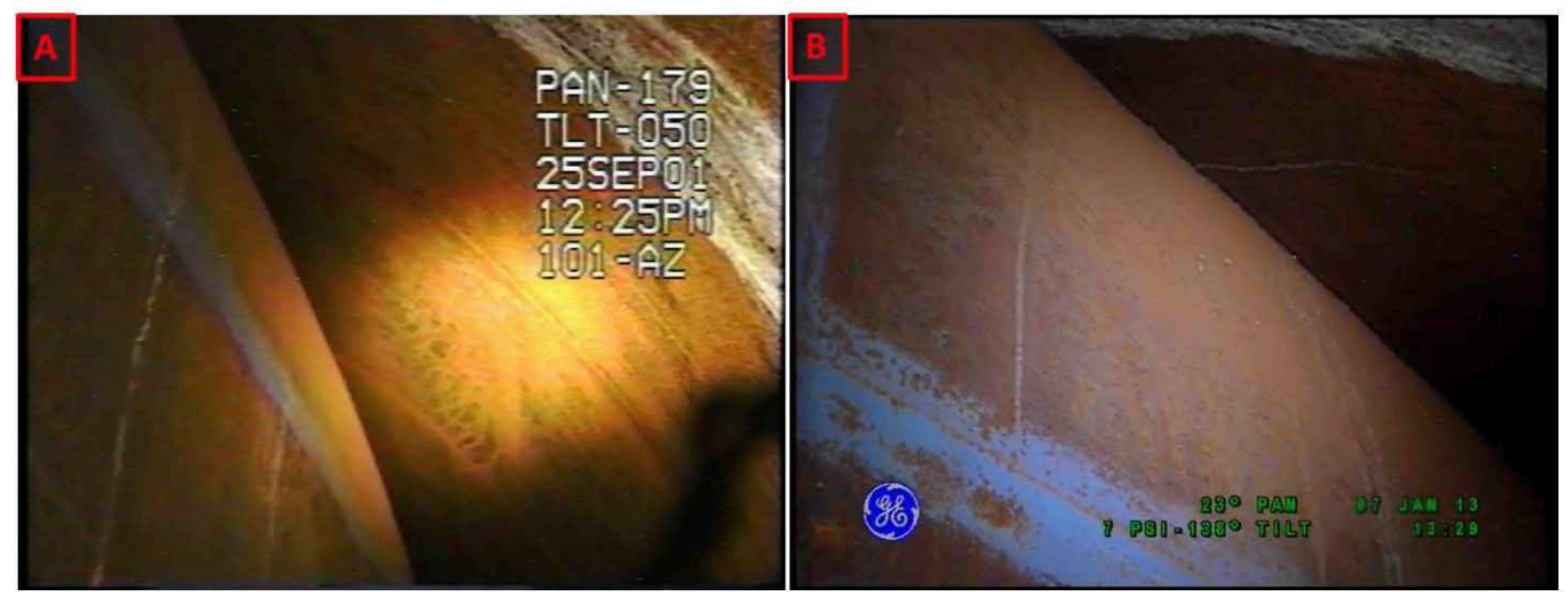

Figure 2-27. Riser 86 Upper Haunch Comparisons Between Inspections on September 25, 2001 (A) and January 7, 2013 (B) Looking Towards Riser 103

\section{Sidewall Comparison - Riser 86}

The sidewall of the primary tank appears to be in good condition and no areas of interest were identified on the primary tank sidewall during the 2013 inspection. 


\section{Lower Knuckle and Annulus Floor Comparisons - Riser 86}

Figure 2-28 and Figure 2-29 show comparisons of the lower knuckle and annulus floor between inspections performed in 2001 and 2013. A beachline can also be seen along the annulus floor in Figure 2-28 and Figure 2-29 which is likely the result of evaporated couplant water used during UT examinations. There appears to be no significant change in the condition of this area between 2001 and 2013. Figure 2-30 shows the general condition of the refractory slots in 2013 and no anomalies were noted. No anomalies were identified on the lower knuckle of the primary tank, insulating refractory, refractory slots, stiffener ring, or annulus floor during the 2013 inspection.
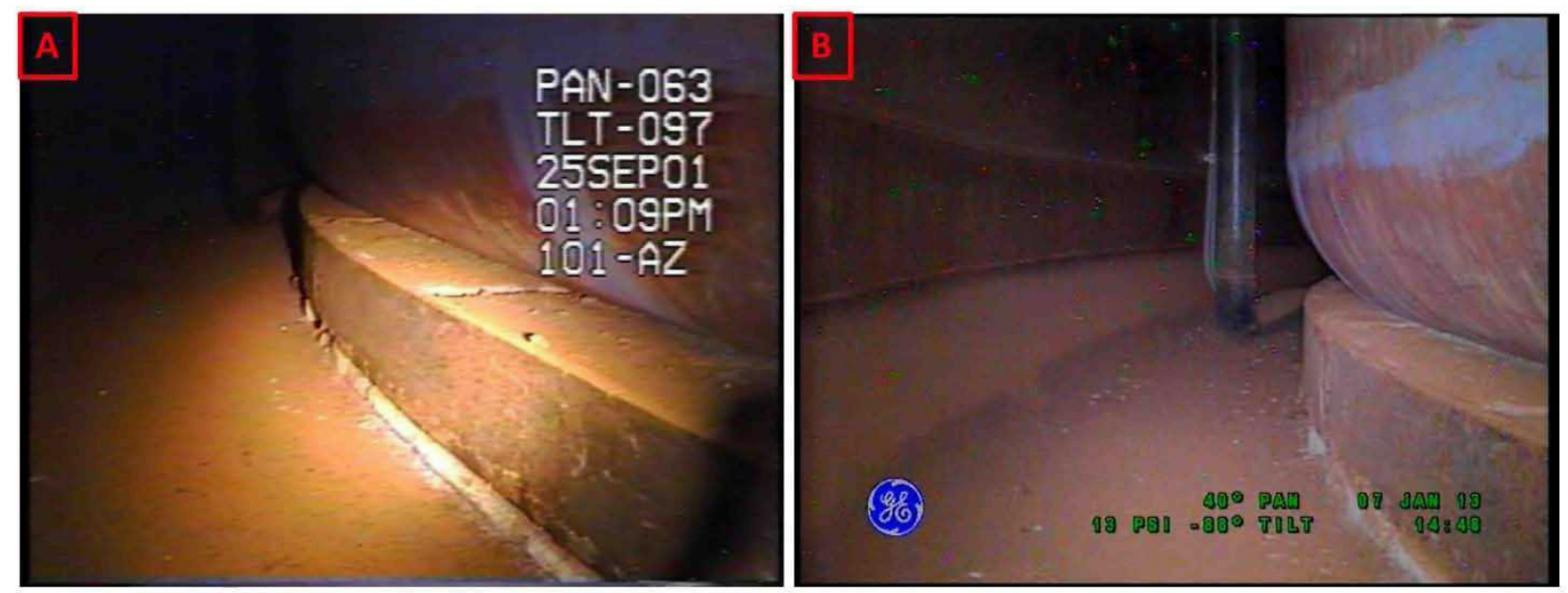

Figure 2-28. Riser 86 Lower Knuckle and Annulus Floor Comparisons Between Inspections on September 25, 2001 (A) and January 7, 2013 (B) Looking Towards Riser 87
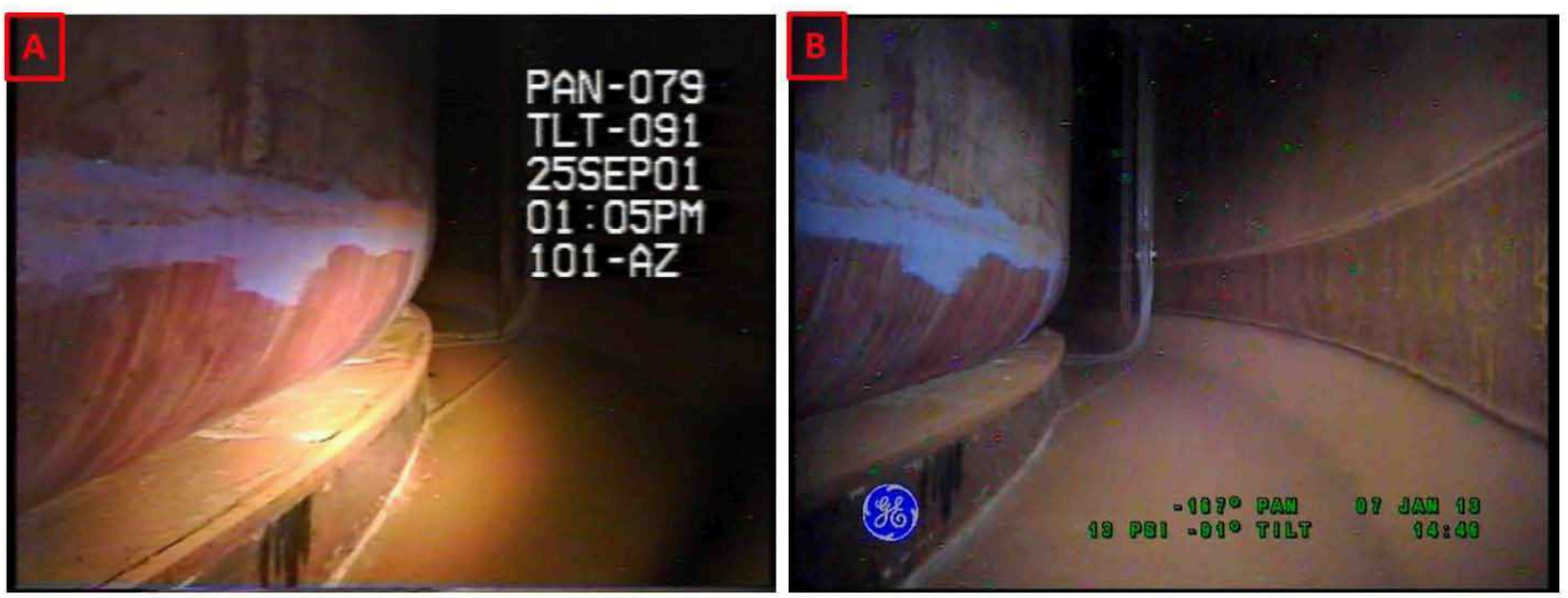

Figure 2-29. Riser 86 Lower Knuckle and Annulus Floor Comparisons Between Inspections on September 25, 2001 (A) and January 7, 2013 (B) Looking Towards Riser 103 


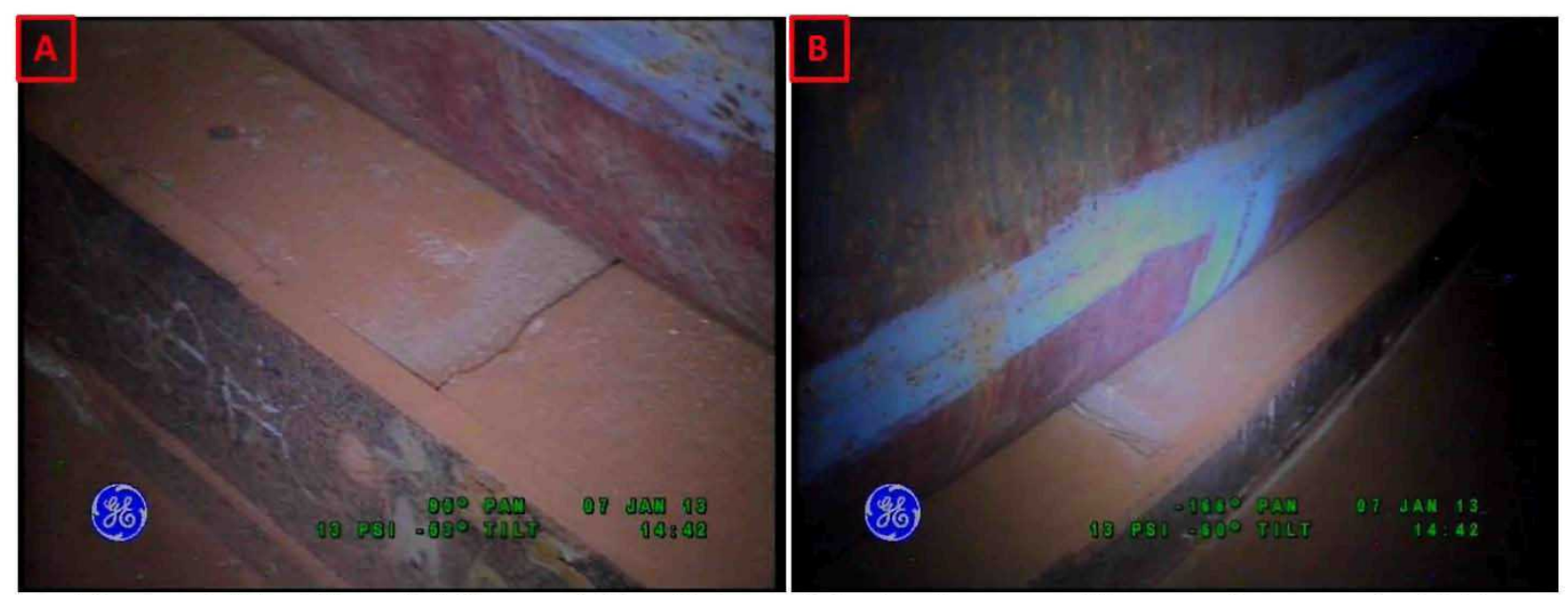

Figure 2-30. Riser 86 General Condition of the Refractory Slots on January 7, 2013

\subsubsection{Tank AZ-101 Riser 88}

Visual inspection results performed through Riser 88 in 2013 are presented below. There were no previous inspections performed through Riser 88 for comparisons.

\section{Tank Dome and Upper Haunch - Riser 88}

Figure 2-31 shows the general condition of the upper haunch area in January 2013. No areas of interest were identified in the top knuckle region during the 2013 inspection.
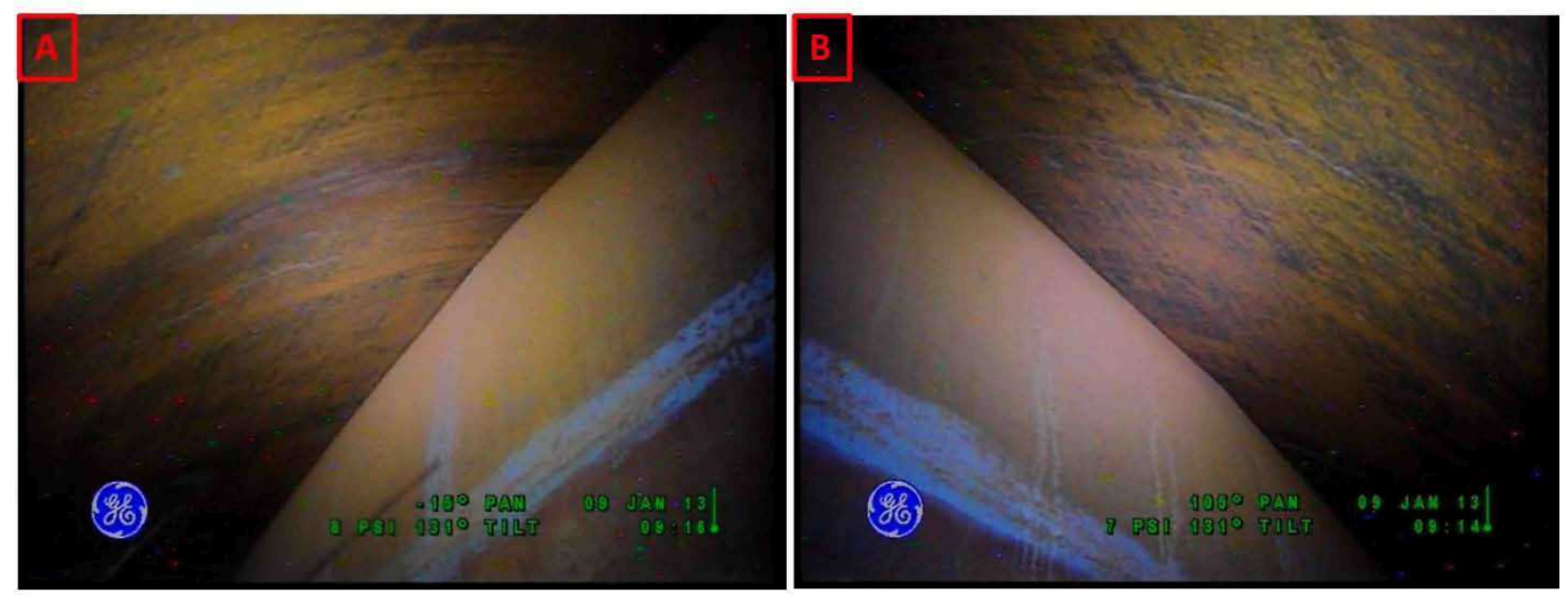

Figure 2-31. Riser 88 General Condition of the Upper Haunch on January 9, 2013 Looking Towards Riser 90 (A) and Looking Towards Riser 104 (B)

\section{Sidewall Comparison - Riser 88}

The sidewall of the primary tank appears to be in good condition and no areas of interest were identified on the primary tank sidewall during the 2013 inspection. 


\section{Lower Knuckle and Annulus Floor Comparison - Riser 88}

Figure 2-32 shows the general condition of the lower knuckle and annulus floor in January 2013. A beachline can also be seen along the annulus floor in Figure 2-32 which is likely the result of evaporated couplant water used during UT examinations. Figure 2-33 shows the general condition of the refractory slots in January 2013 and no anomalies were noted. No anomalies were identified on the lower knuckle of the primary tank, insulating refractory, refractory slots, stiffener ring, or annulus floor during the 2013 inspection.
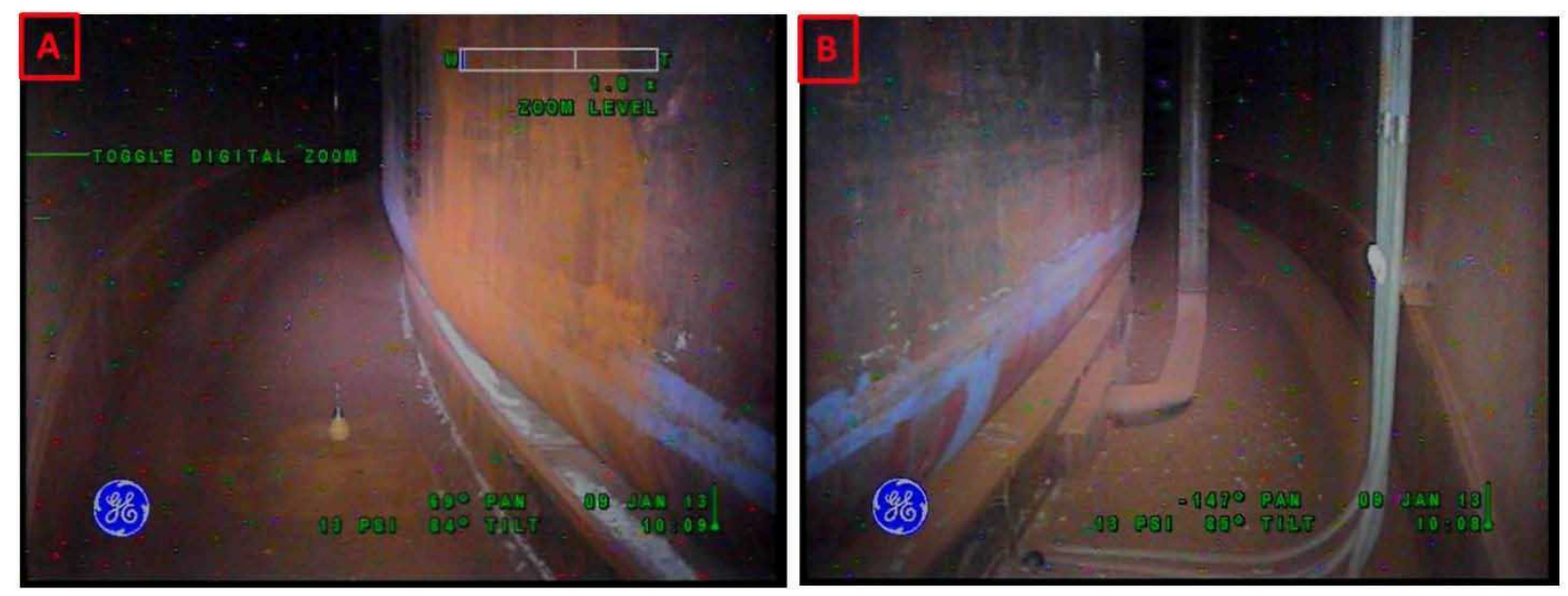

Figure 2-32. Riser 88 Lower Knuckle and Annulus Floor Condition on January 9, 2013 Looking Towards Riser 90 (A) and Looking Towards Riser 104 (B)
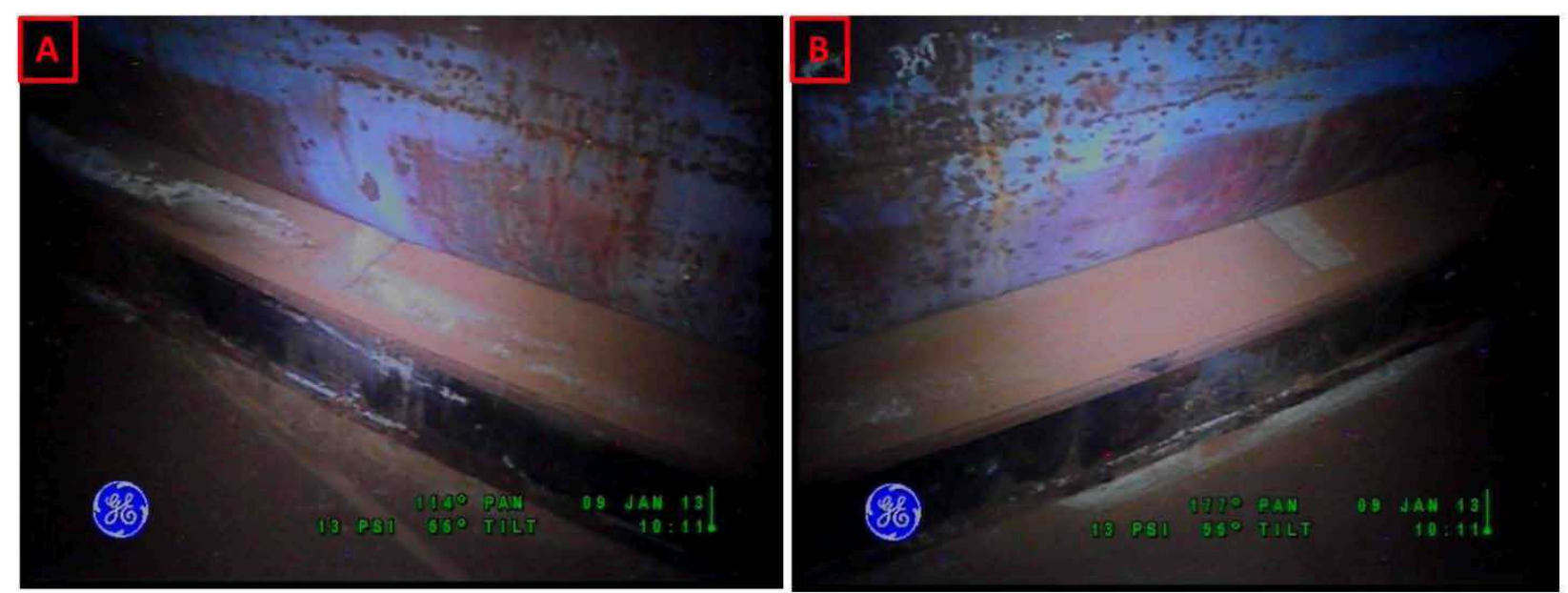

Figure 2-33. Riser 88 General Condition of the Refractory Slots on January 9, 2013

\subsubsection{Tank AZ-101 Riser 89}

Visual inspection results performed through Riser 89 in 2013 are presented below. There were no previous inspections performed through Riser 89 for comparisons. 


\section{Tank Dome and Upper Haunch - Riser 89}

Figure 2-34 shows the general condition of the upper haunch area in January 2013. No areas of interest were identified in the top knuckle region during the 2013 inspection.
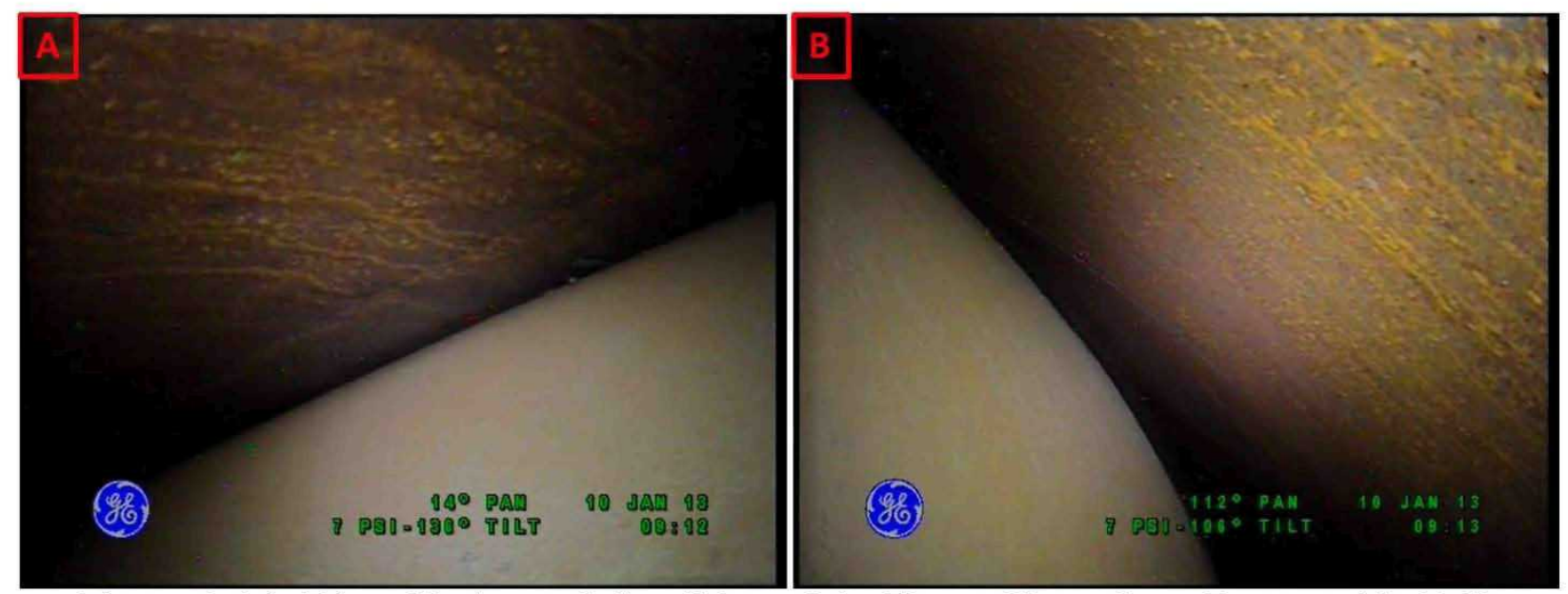

Figure 2-34. Riser 89 General Condition of the Upper Haunch on January 10, 2013 Looking Towards Riser 83 (A) and Looking Towards Riser 101 (B)

\section{Sidewall Comparison - Riser 89}

The sidewall of the primary tank appears to be in good condition and no areas of interest were identified on the primary tank sidewall during the 2013 inspection.

\section{Lower Knuckle and Annulus Floor Comparisons - Riser 89}

Figure 2-35 shows the general condition of the lower knuckle and annulus floor in January 2013. A beachline and can also be seen along the annulus floor in Figure 2-35 which is likely the result of evaporated couplant water used during UT examinations. Riser 89 is one of the risers that is utilized for UT examinations which explains why there is more areas of discoloration seen on the annulus floor compared with other risers of tank AZ-101. Figure 2-36 shows the general condition of the refractory slots in January 2013 and no anomalies were noted. No anomalies were identified on the lower knuckle of the primary tank, insulating refractory, refractory slots, stiffener ring, or annulus floor during the 2013 inspection. 


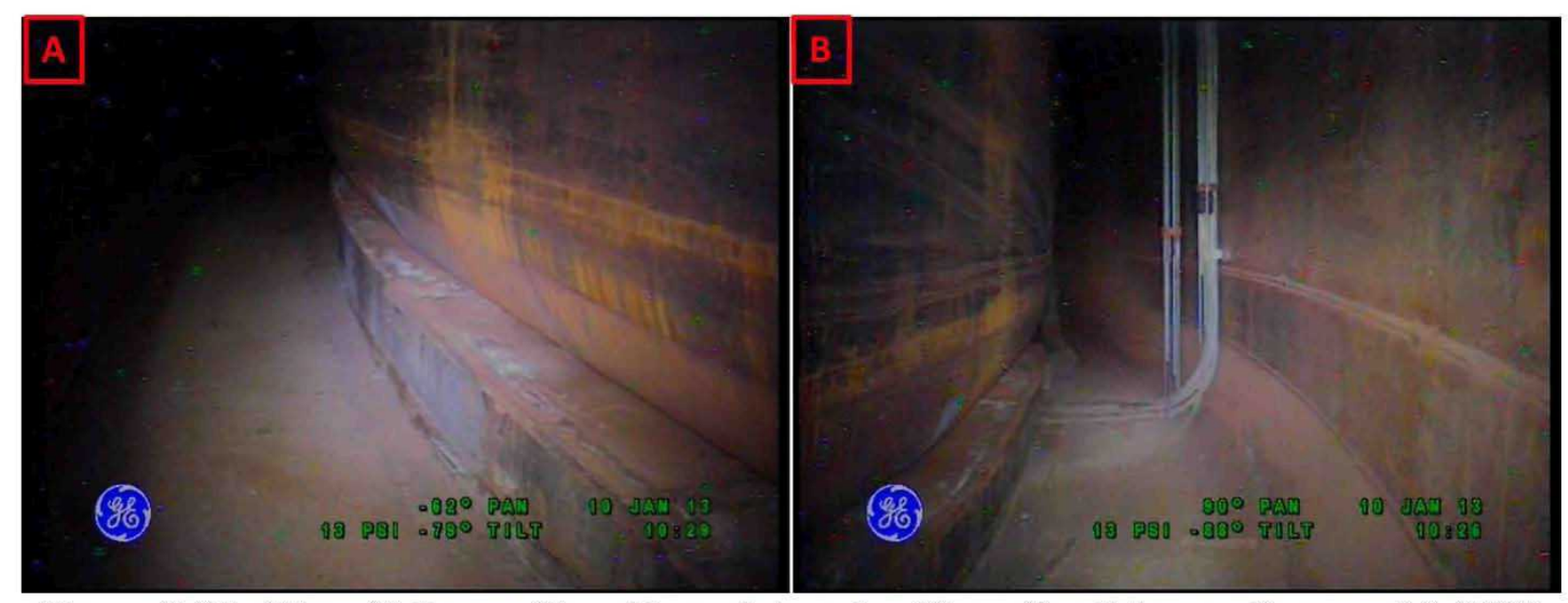

Figure 2-35. Riser 89 Lower Knuckle and Annulus Floor Condition on January 10, 2013 Looking Towards Riser 83 (A) and Looking Towards Riser 101 (B)

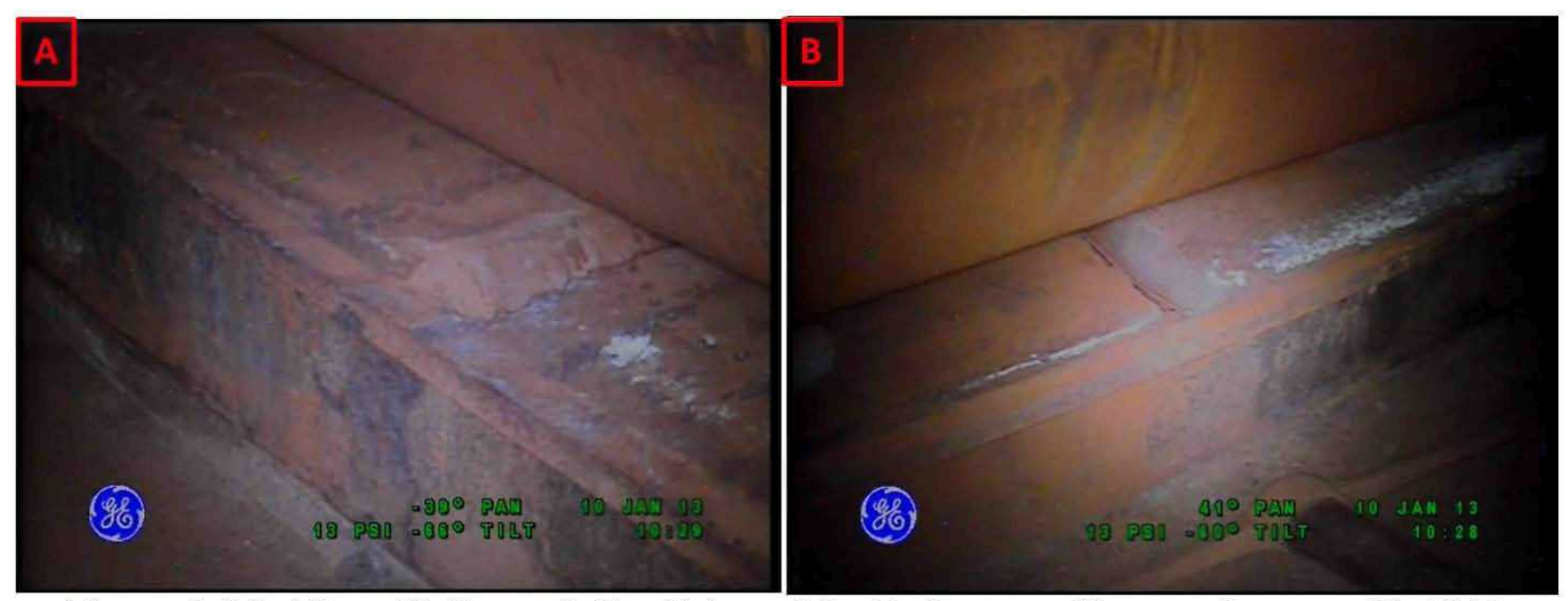

Figure 2-36. Riser 89 General Condition of the Refractory Slots on January 10, 2013

\subsubsection{Tank AZ-101 Riser 91}

Visual inspection results performed through Riser 91 in 2013 are presented below. There were no previous inspections performed through Riser 91 for comparisons.

\section{Tank Dome and Upper Haunch - Riser 91}

Figure 2-37 shows the general condition of the upper haunch area in January 2013. No areas of interest were identified in the top knuckle region during the 2013 inspection. 

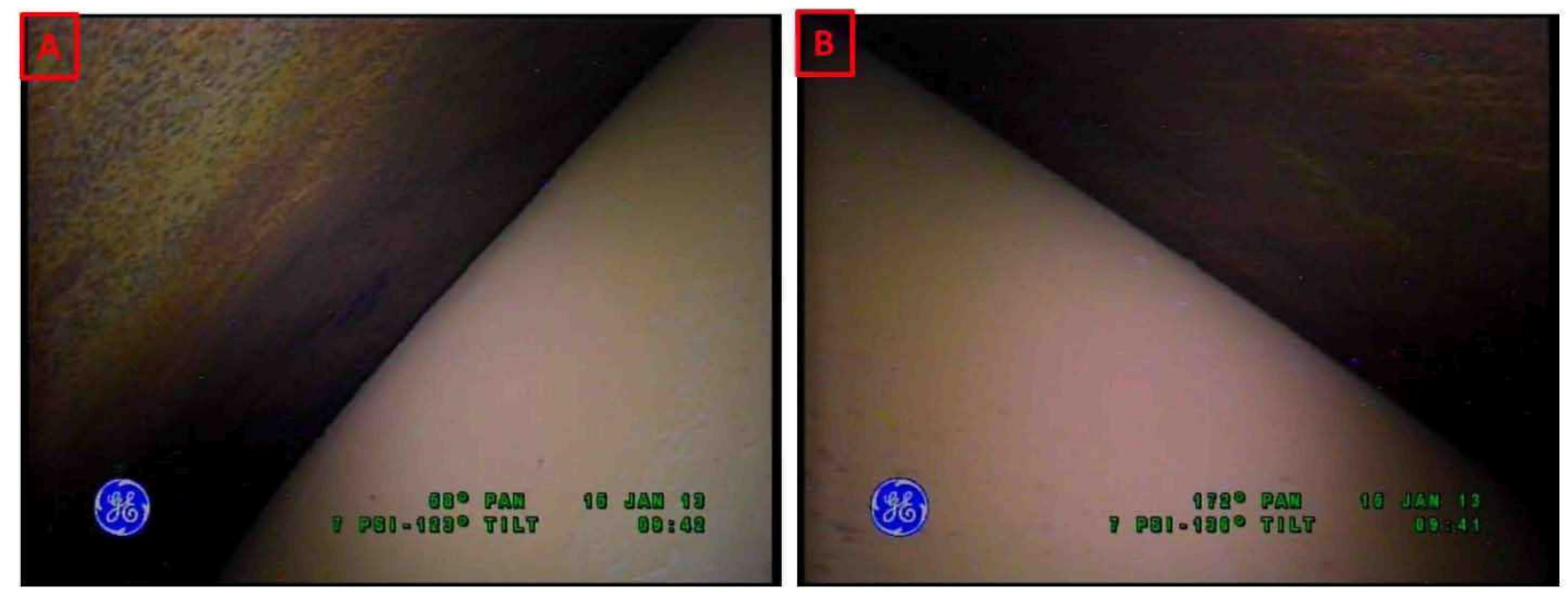

Figure 2-37. Riser 91 General Condition of the Upper Haunch on January 15, 2013 Looking Towards Riser 94 (A) and Looking Towards Riser 80 (B)

\section{Sidewall Comparison - Riser 91}

The sidewall of the primary tank appears to be in good condition and no areas of interest were identified on the primary tank sidewall during the 2013 inspection.

\section{Lower Knuckle and Annulus Floor Comparisons - Riser 91}

Figure 2-38 shows the general condition of the lower knuckle and annulus floor in January 2013. A beachline can also be seen along the annulus floor in Figure 2-38 which is likely the result of evaporated couplant water used during UT examinations. Figure 2-39 shows the general condition of the refractory slots in January 2013 and no anomalies were noted. No anomalies were identified on the lower knuckle of the primary tank, insulating refractory, refractory slots, stiffener ring, or annulus floor during the 2013 inspection.
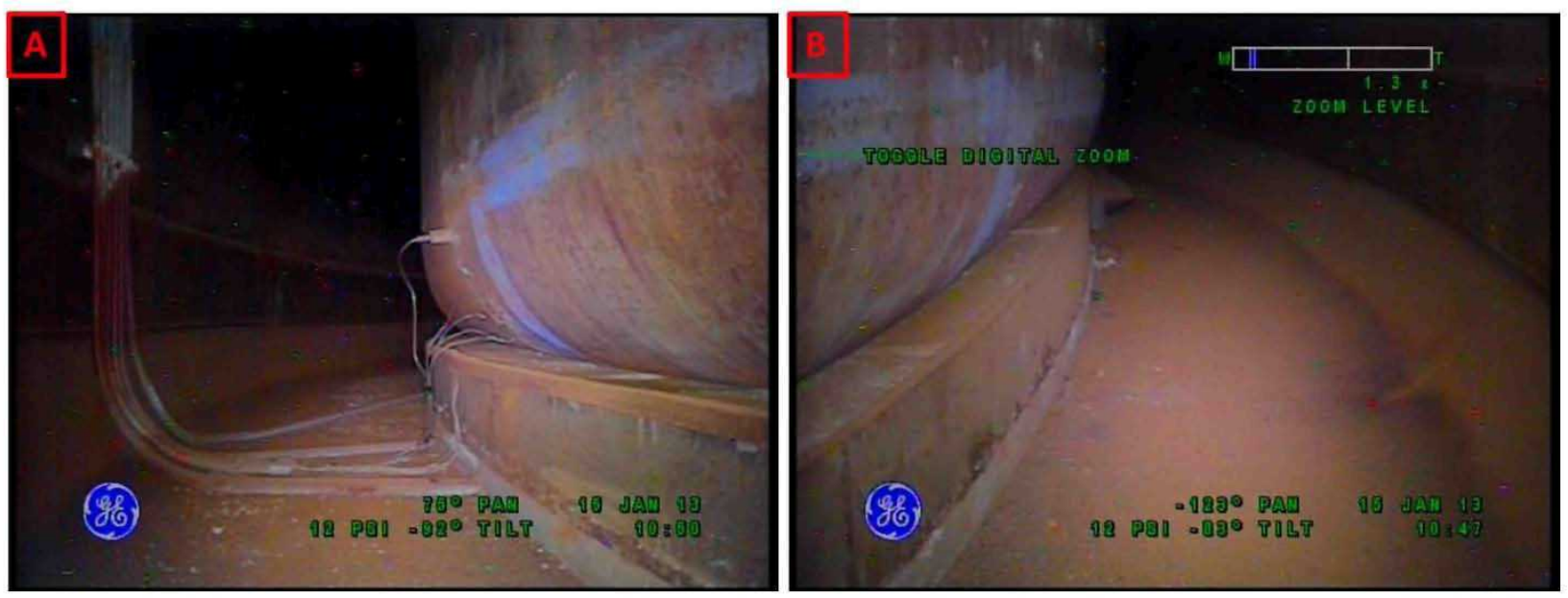

Figure 2-38. Riser 91 Lower Knuckle and Annulus Floor Condition on January 15, 2013 Looking Towards Riser 94 (A) and Looking Towards Riser 80 (B) 


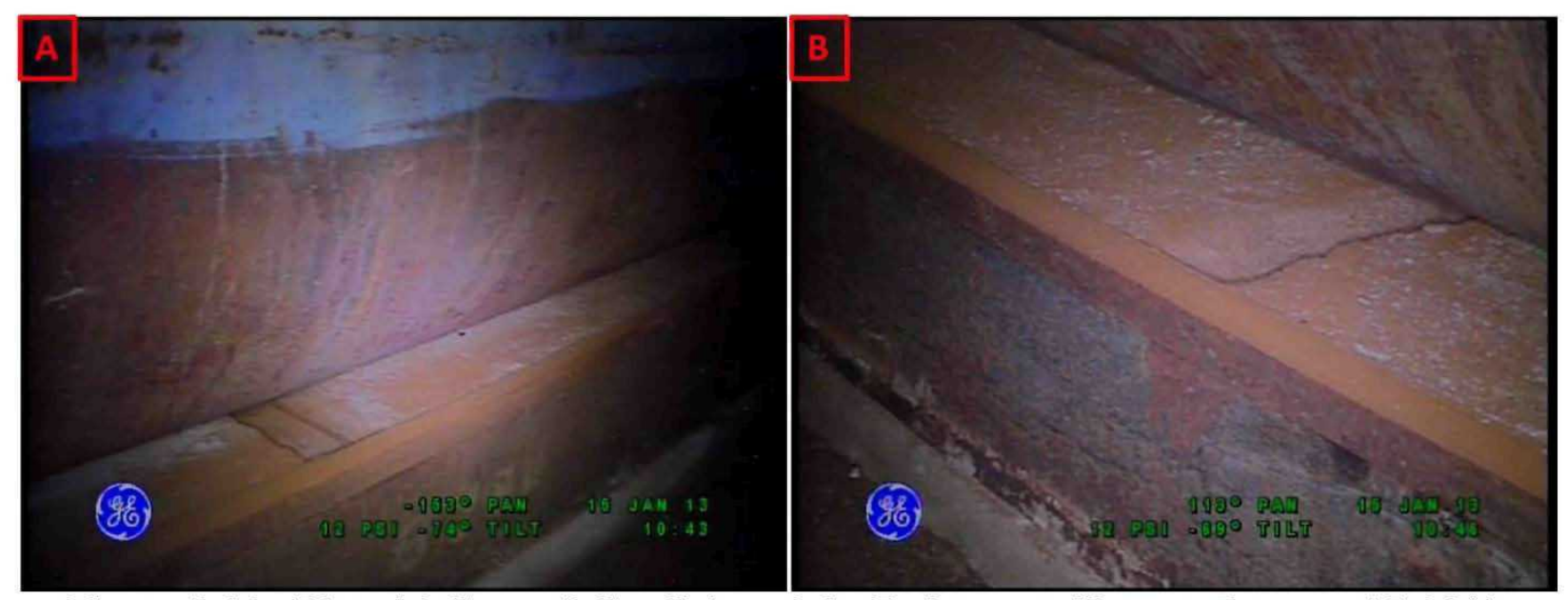

Figure 2-39. Riser 91 General Condition of the Refractory Slots on January 15, 2013

\subsubsection{Tank AZ-101 Riser 92}

Visual inspection results performed through Riser 92 in 2013 are presented below. There were no previous inspections performed through Riser 92 for comparisons.

\section{Tank Dome and Upper Haunch - Riser 92}

Figure 2-40 shows the general condition of the upper haunch area in January 2013. No areas of interest were identified in the top knuckle region during the 2013 inspection.
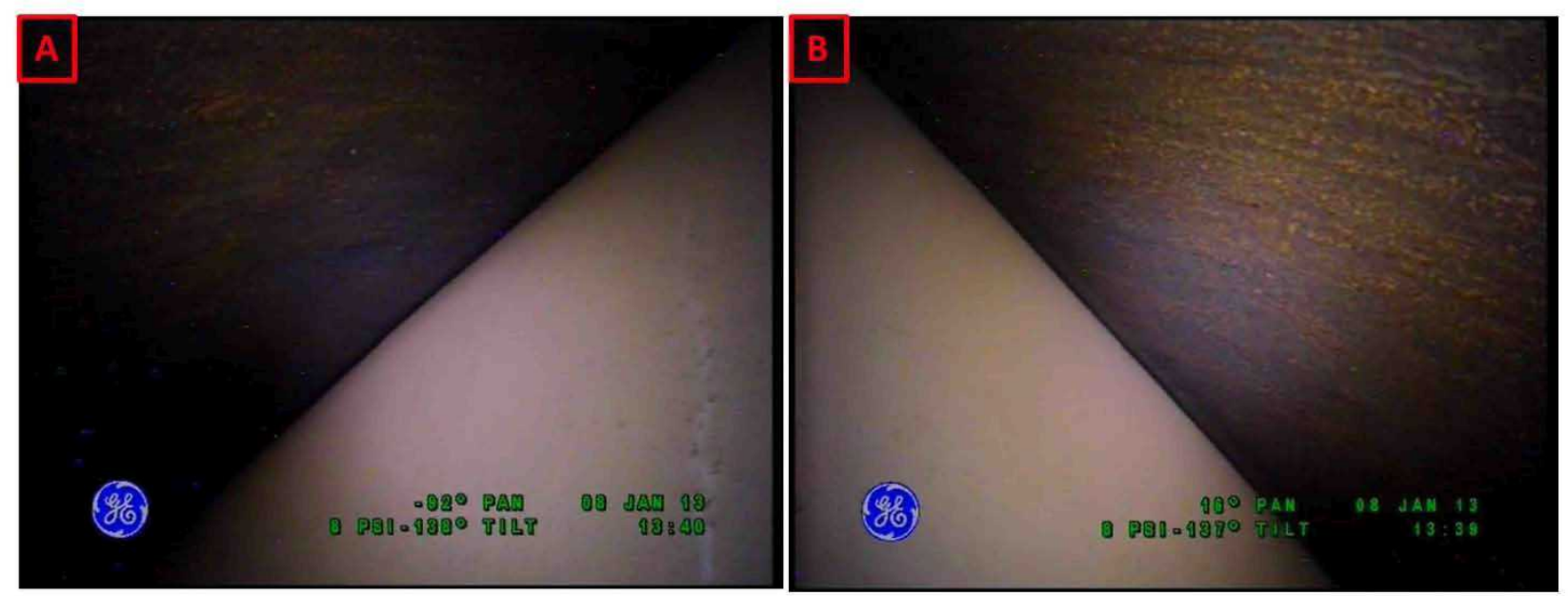

Figure 2-40. Riser 92 General Condition of the Upper Haunch on January 8, 2013 Looking Towards Riser 97 (A) and Looking Towards Riser 85 (B)

\section{Sidewall Comparison - Riser 92}

The sidewall of the primary tank appears to be in good condition and no areas of interest were identified on the primary tank sidewall during the 2013 inspection. 


\section{Lower Knuckle and Annulus Floor Comparison - Riser 92}

Figure 2-41 shows the general condition of the lower knuckle and annulus floor in January 2013. A beachline can also be seen along the annulus floor in Figure 2-41 which is likely the result of evaporated couplant water used during UT examinations. Figure 2-42 shows the general condition of the refractory slots in January 2013 and no anomalies were noted. No anomalies were identified on the lower knuckle of the primary tank, insulating refractory, refractory slots, stiffener ring, or annulus floor during the 2013 inspection.
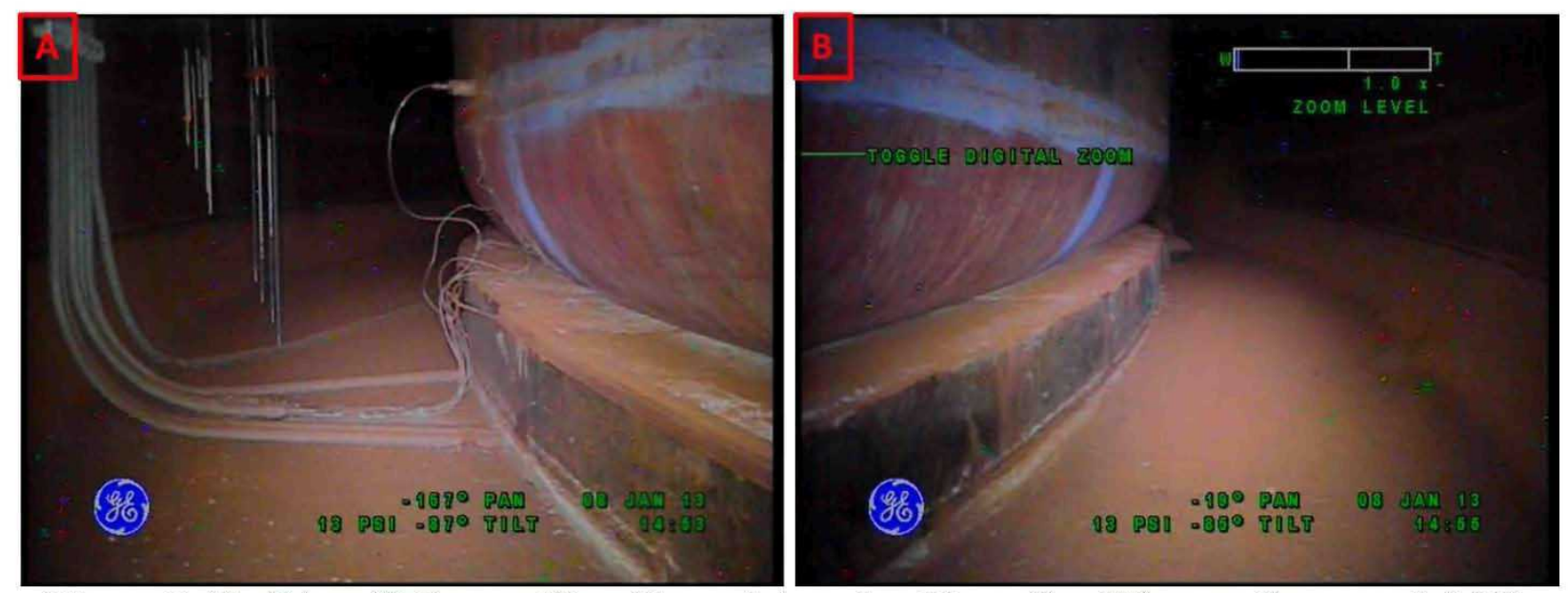

Figure 2-41. Riser 92 Lower Knuckle and Annulus Floor Condition on January 8, 2013 Looking Towards Riser 97 (A) and Looking Towards Riser 85 (B)
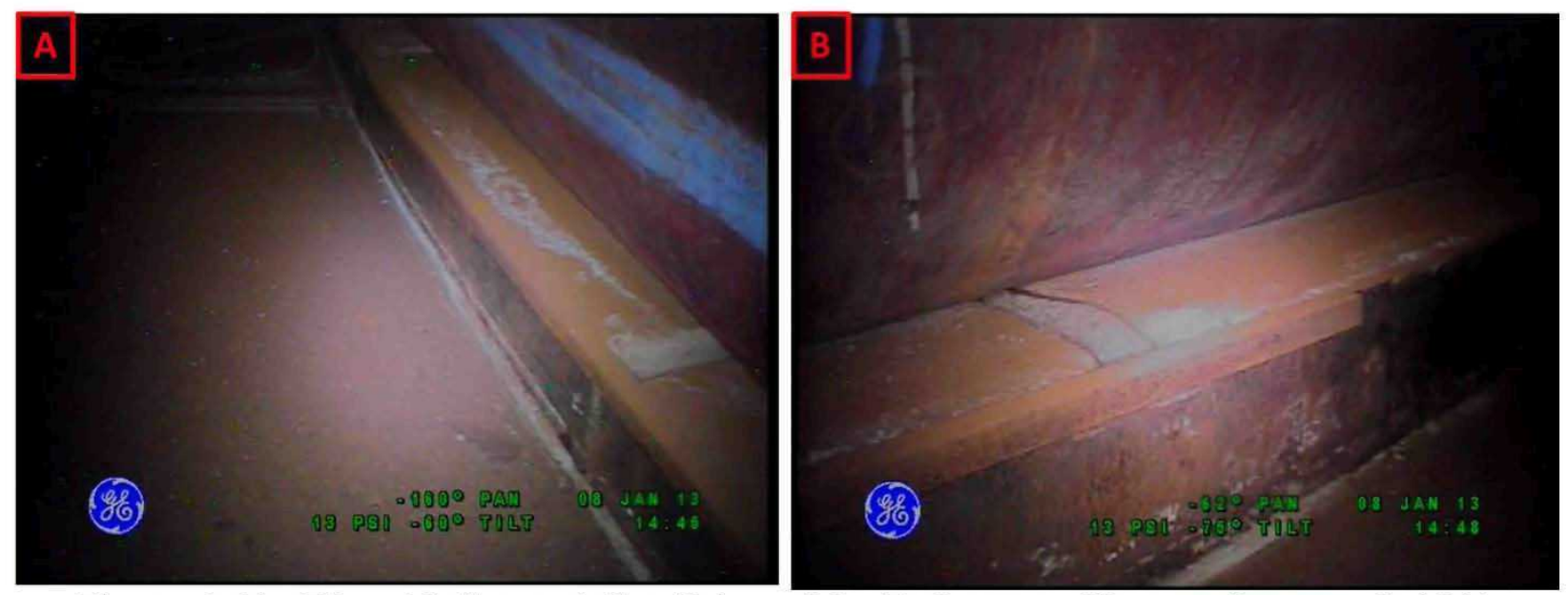

Figure 2-42. Riser 92 General Condition of the Refractory Slots on January 8, 2013 


\subsection{TANK AZ-102 BASELINE VIDEO INSPECTIONS}

Results of the previous 241-AZ Farm visual inspections are documented in RPP-RPT-34310, Rev. 0, Double-Shell Tank Integrity Inspection Report for 241-AZ Tank Farm. The evaluation factors that make up the inspection criteria for the annulus visual inspections are documented in RPP-PLAN-46847, Rev. 0, Visual Inspection Plan for Single-Shell Tanks and Double-Shell Tanks. Beginning in January 2013 through February 2013, visual inspections were performed in eleven risers for tank AZ-102 to provide a baseline inspection, covering $>95 \%$ of annulus floor area, and the portion of the primary tank (i.e., dome, sidewall, lower knuckle, and insulating refractory) that is visible from the annulus inspection risers. Photographs of the general condition of the upper haunch of the primary tank, the bottom knuckle, insulating refractory, refractory slots, stiffener ring, and annulus floor are included in the following subsections with any areas of interest noted. A statement of the general condition of the primary tank sidewall as seen through each riser will be included as well as any areas of interest; however, areas of interest on the sidewall will be noted and included in the update to document RPP-RPT-34310, Rev. 0.

The following sections contain screen shots taken of the 2013 baseline inspection performed in designated risers shown in Figure ES-2. In the cases where there are no areas of interest, then a review of the oldest inspection was used for comparisons. However, if anomalies are noted then all previous inspection videos were reviewed to identify any possible changes in the condition of the area of interest.

\subsection{TANK AZ-102 ANNULUS RISER INSPECTIONS}

The tank AZ-102 annulus video inspection risers locations are shown in Figure ES-2. Table 3-1 lists the years of previous inspections and the risers utilized for the 2013 baseline inspections.

Table 3-1. Tank AZ-102 Annulus Riser Visual Inspections

\begin{tabular}{|c|c|c|}
\hline \multicolumn{3}{|c|}{1993} \\
\hline $\begin{array}{c}\text { Riser } \\
\text { Number }\end{array}$ & $\begin{array}{c}\text { Date of } \\
\text { Inspection }\end{array}$ & $\begin{array}{c}\text { DVDID } \\
\text { Number }\end{array}$ \\
\hline $78(17 \mathrm{~A})$ & $07 / 30 / 1993$ & 10407 \\
\hline $84(17 \mathrm{G})$ & $07 / 27 / 1993$ & 10408 \\
\hline
\end{tabular}

\begin{tabular}{|c|c|c|}
\hline \multicolumn{3}{|c|}{$\mathbf{2 0 0 7}$} \\
\hline $\begin{array}{c}\text { Riser } \\
\text { Number }\end{array}$ & $\begin{array}{c}\text { Date of } \\
\text { Inspection }\end{array}$ & $\begin{array}{c}\text { DVDID } \\
\text { Number }\end{array}$ \\
\hline 80 & $07 / 30 / 2007$ & 11179 \\
\hline 82 & $07 / 30 / 2007$ & 11187 \\
\hline 85 & $07 / 30 / 2007$ & 11186 \\
\hline 87 & $07 / 30 / 2007$ & 11188 \\
\hline
\end{tabular}

\begin{tabular}{|c|c|c|}
\hline \multicolumn{3}{|c|}{$\mathbf{2 0 1 3}$} \\
\hline $\begin{array}{c}\text { Riser } \\
\text { Number }\end{array}$ & $\begin{array}{c}\text { Date of } \\
\text { Inspection }\end{array}$ & $\begin{array}{c}\text { DVDID } \\
\text { Number }\end{array}$ \\
\hline 78 & $01 / 28 / 2013$ & 11634 \\
\hline 79 & $01 / 23 / 2013$ & 11635 \\
\hline 80 & $02 / 14 / 2013$ & 11636 \\
\hline 81 & $01 / 22 / 2013$ & 11637 \\
\hline 82 & $01 / 22 / 2013$ & 11638 \\
\hline 83 & $01 / 05 / 2013$ & 11639 \\
\hline 84 & $01 / 05 / 2013$ & 11640 \\
\hline 86 & $01 / 31 / 2013$ & 11641 \\
\hline 88 & $01 / 31 / 2013$ & 11642 \\
\hline 89 & $02 / 27 / 2013$ & 11643 \\
\hline 92 & $02 / 11 / 2013$ & 11644 \\
\hline
\end{tabular}

Note: Risers 89 and 90 were utilized for previous UT examinations 


\subsection{TANK AZ-102 2013 BASELINE INSPECTION RESULTS AND COMPARISONS TO PREVIOUS INSPECTIONS}

\subsubsection{Tank AZ-102 Riser 78}

Visual inspections performed through Riser 78 in 1993 and 2013 were compared and results are presented below.

\section{Tank Dome and Upper Haunch - Riser 78}

Figure 3-1 and Figure 3-2 show comparisons of the upper haunch area between inspections performed in 1993 and 2013. Since the camera was lower in the 1993 inspection, it is difficult to compare the top knuckle area with the 2013 inspection. However, there appears to be no significant changes in the condition of this area from 1993 to 2013. No areas of interest were identified in the top knuckle region during the 2013 inspection.

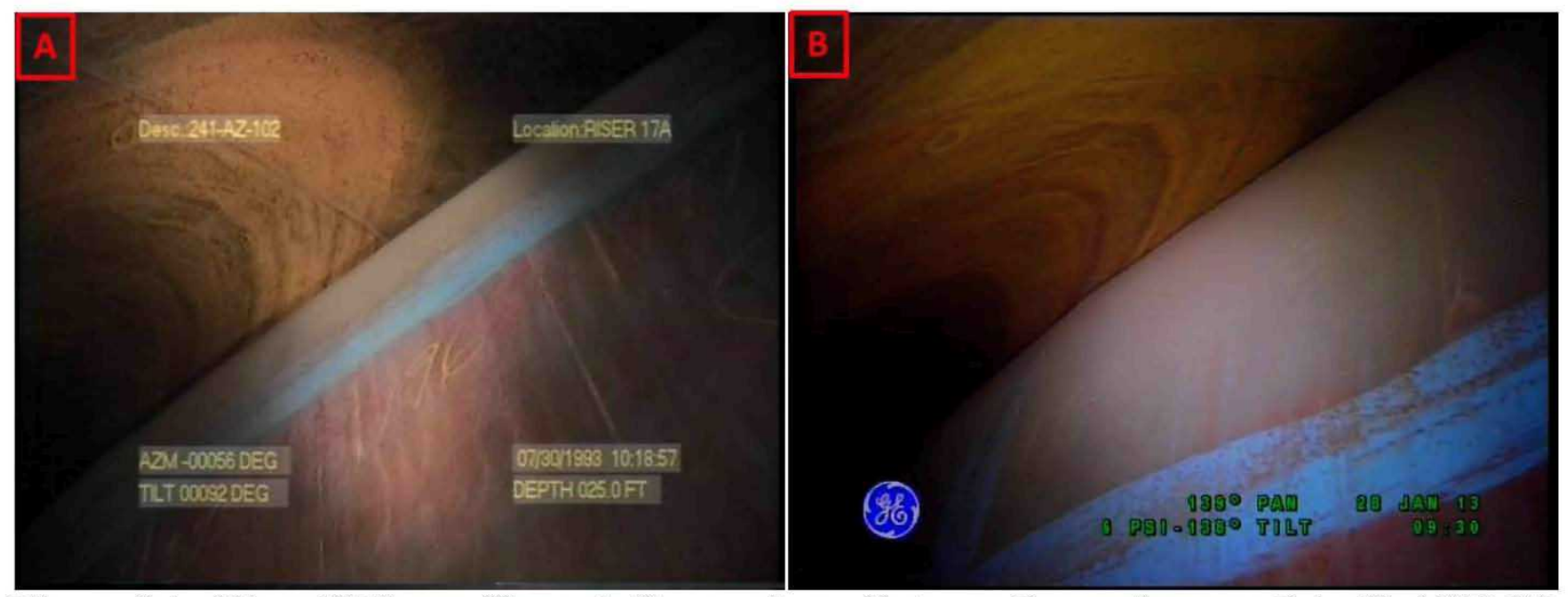

Figure 3-1. Riser 78 Upper Haunch Comparisons Between Inspections on July 30, 1993 (A) and January 28, 2013 (B) Looking Towards Riser 93

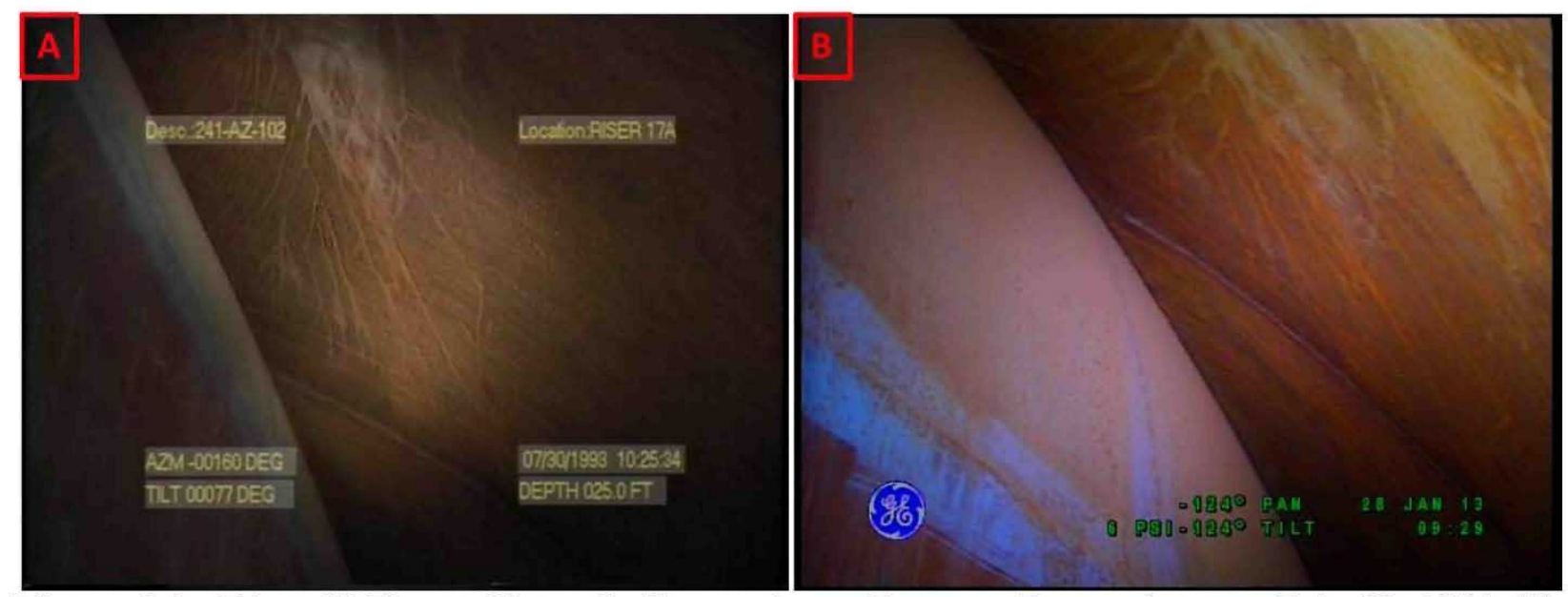

Figure 3-2. Riser 78 Upper Haunch Comparisons Between Inspections on July 30, 1993 (A) and January 28, 2013 (B) Looking Towards Riser 90 


\section{Sidewall Comparison - Riser 78}

The sidewall of the primary tank appears to be in good condition and no areas of interest were identified on the primary tank sidewall during the 2013 inspection.

\section{Lower Knuckle and Annulus Floor Comparisons - Riser 78}

Figure 3-3 and Figure 3-4 show comparisons of the lower knuckle and annulus floor between inspections performed in 1993 and 2013. There appears to be no significant change in the condition of this area between 1993 and 2013. However, in Figure 3-4B there appears to be more staining on the annulus floor in 2013 compared to 1993. This is attributed to the previous UT examinations performed in nearby Riser 90 of the lower knuckle weld. The scanner path can be seen on the tank wall in Figure 3-4B. A beachline can also be seen along the annulus floor in Figure 3-3 and Figure 3-4 which is likely the result of evaporated couplant water used during UT examinations. Figure 3-5 shows the 1993 and 2013 comparison of the condition of the refractory slot and no significant changes in the condition were noted. No anomalies were identified on the lower knuckle of the primary tank, insulating refractory, refractory slots, stiffener ring, or annulus floor during the 2013 inspection.

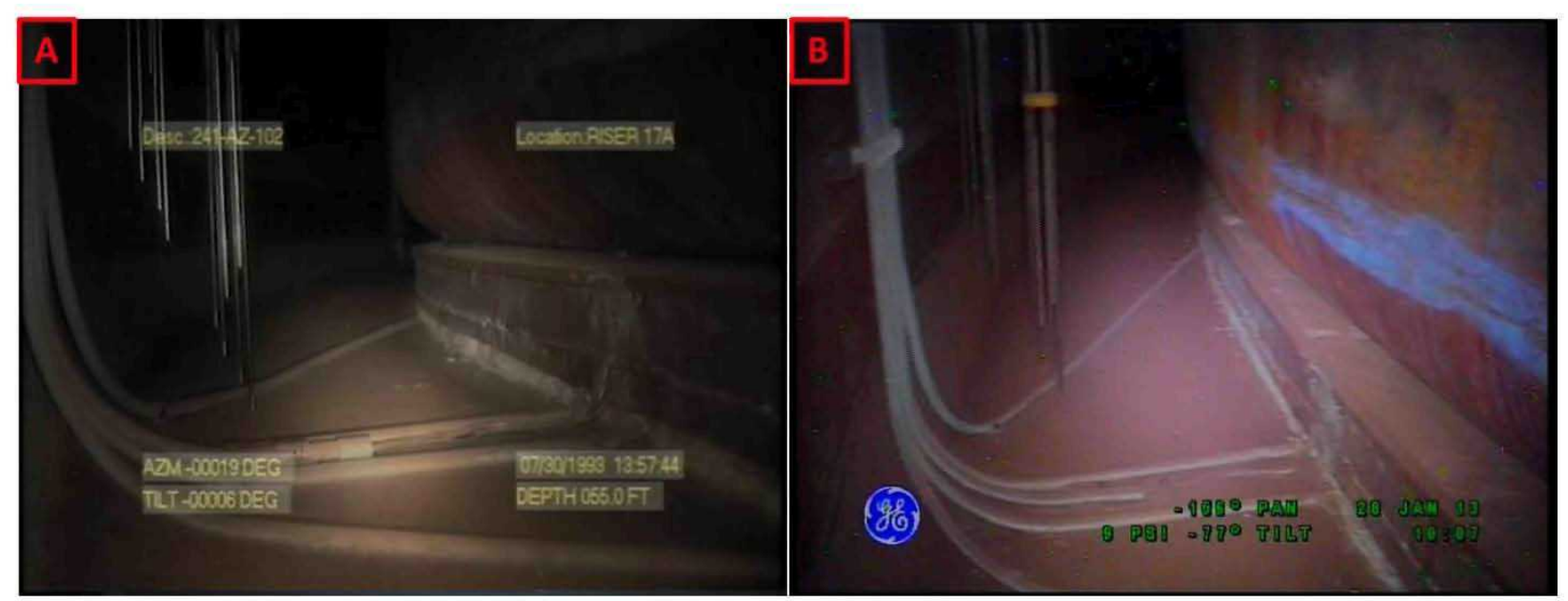

Figure 3-3. Riser 78 Lower Knuckle and Annulus Floor Comparisons Between Inspections on July 30, 1993 (A) and January 28, 2013 (B) Looking Towards Riser 93 


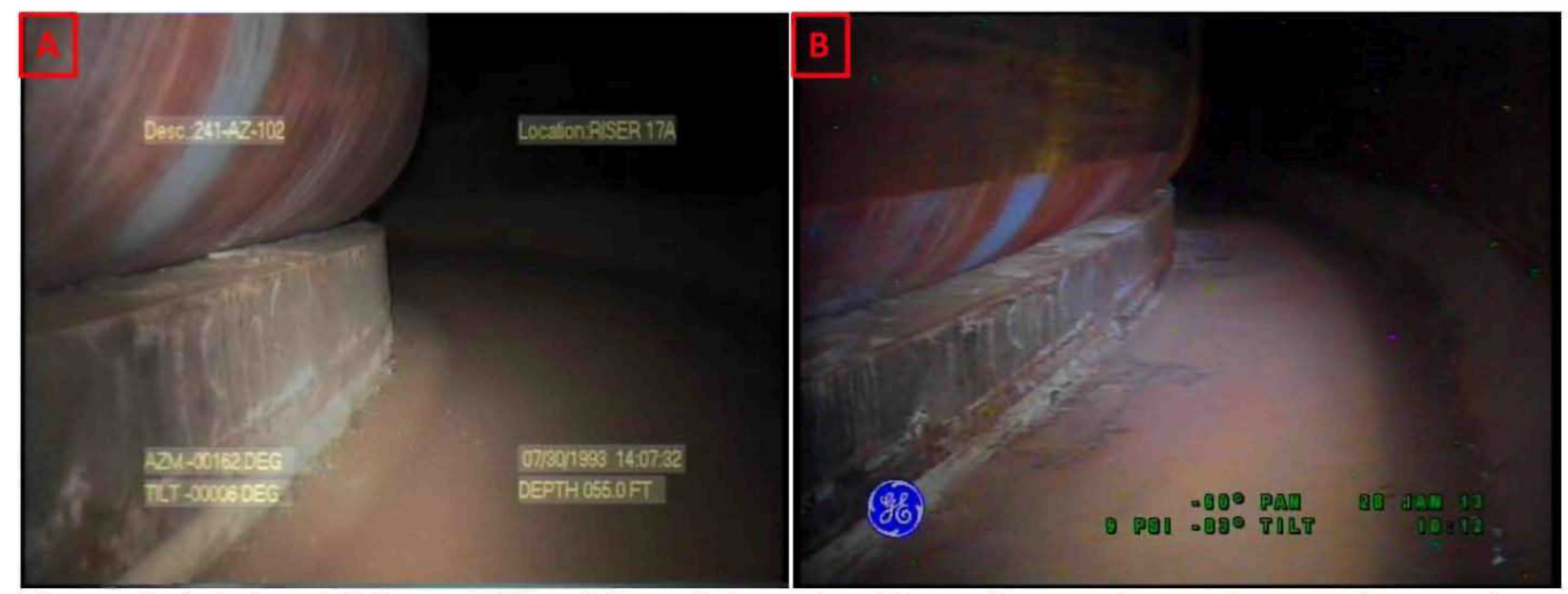

Figure 3-4. Riser 78 Lower Knuckle and Annulus Floor Comparisons Between Inspections on July 30, 1993 (A) and January 28, 2013 (B) Looking Towards Riser 90

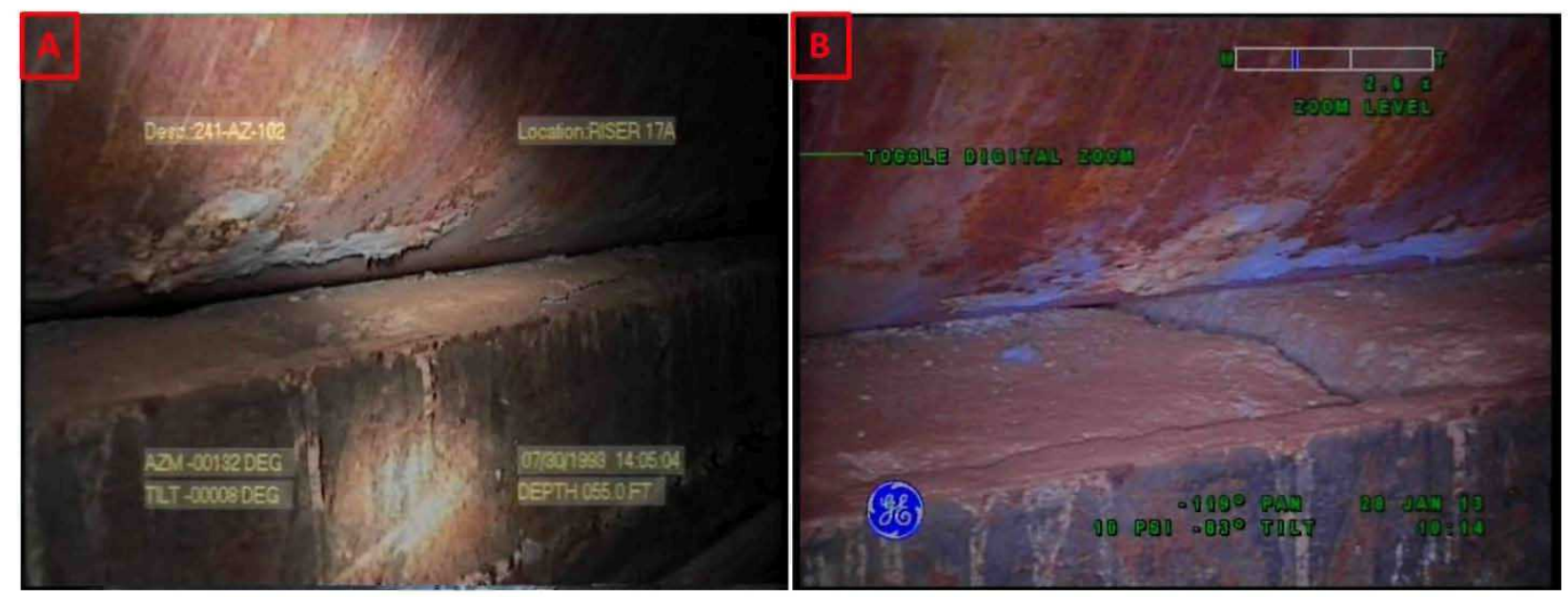

Figure 3-5. Riser 78 General Condition of the Refractory Slots on July 30, 1993 (A) and January 28, 2013 (B)

\subsubsection{Tank AZ-102 Riser 79}

Visual inspection results performed through Riser 79 in 2001 and 2013 were compared and results are presented below.

\section{Tank Dome and Upper Haunch - Riser 79}

The tank dome and upper haunch area were not visible during the 2001 inspection. Figure 3-6 shows the general condition of the upper haunch area in January 2013. No areas of interest were identified in the top knuckle region during the 2013 inspection. 

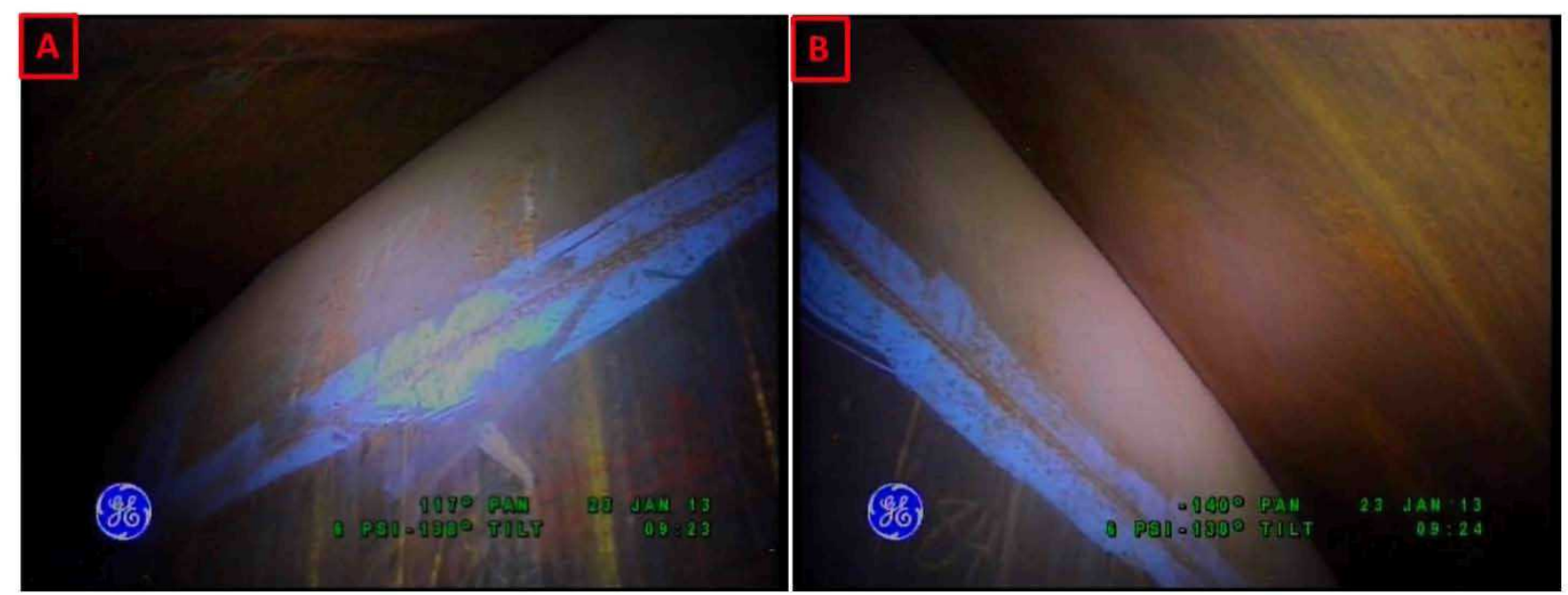

Figure 3-6. Riser 79 General Condition of the Upper Haunch on January 13, 2013 Looking Towards Riser 80 (A) and Looking Towards Riser 99 (B)

\section{Sidewall Comparison - Riser 79}

The sidewall of the primary tank appears to be in good condition and no areas of interest were identified on the primary tank sidewall during the 2013 inspection.

\section{Lower Knuckle and Annulus Floor Comparisons - Riser 79}

Figure 3-7 and Figure 3-8 show comparisons of the lower knuckle and annulus floor between inspections performed in 2001 and 2013. There appears to be no significant change in the condition of this area between 2001 and 2013. Figure 3-9 shows the general condition of the refractory slots in 2013 and no anomalies were noted. No anomalies were identified on the lower knuckle of the primary tank, insulating refractory, refractory slots, stiffener ring, or annulus floor during the 2013 inspection.

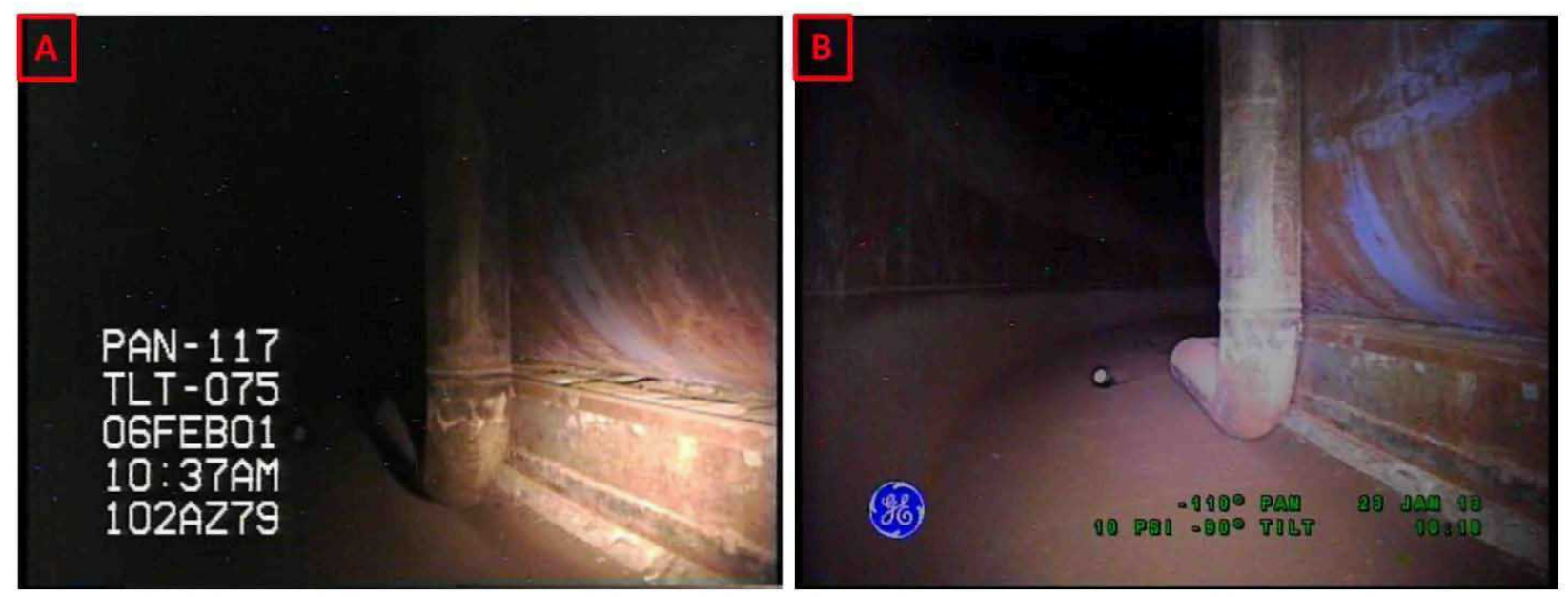

Figure 3-7. Riser 79 Lower Knuckle and Annulus Floor Comparisons Between Inspections on February 6, 2001 (A) and January 23, 2013 (B) Looking Towards Riser 80 


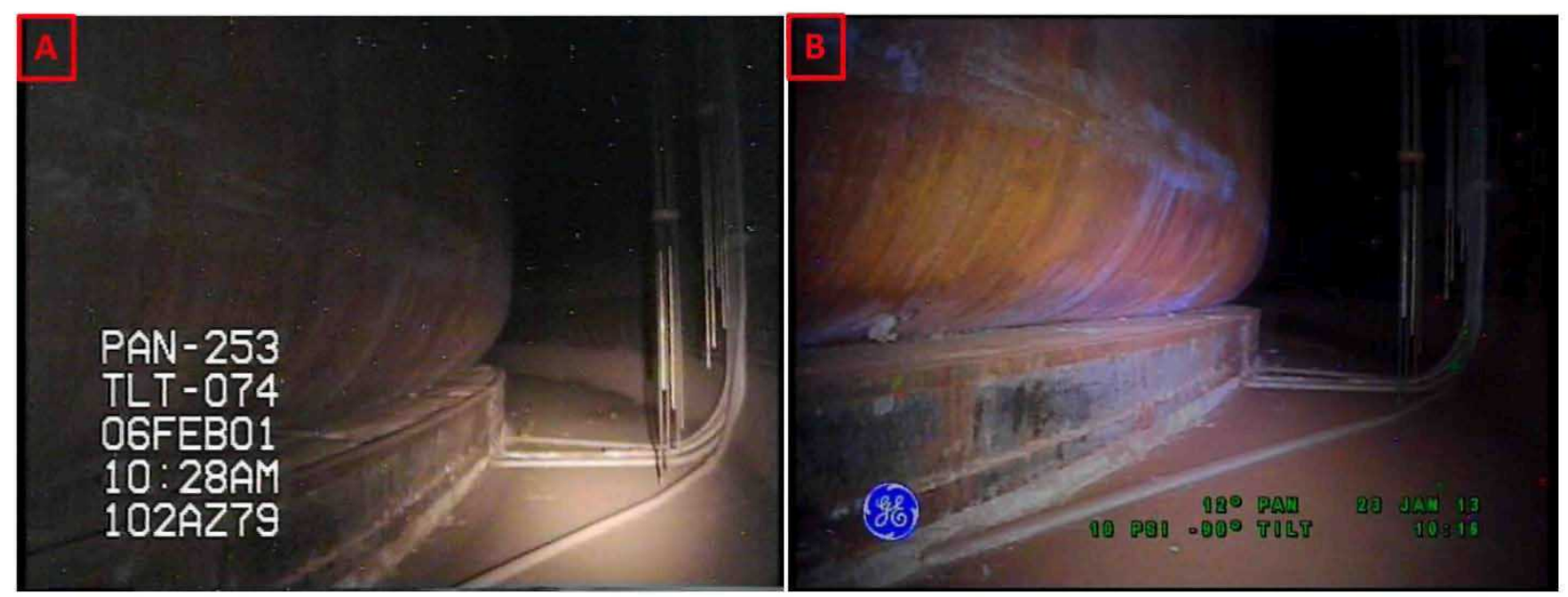

Figure 3-8. Riser 79 Lower Knuckle and Annulus Floor Comparisons Between Inspections on February 6, 2001 (A) and January 23, 2013 (B) Looking Towards Riser 99

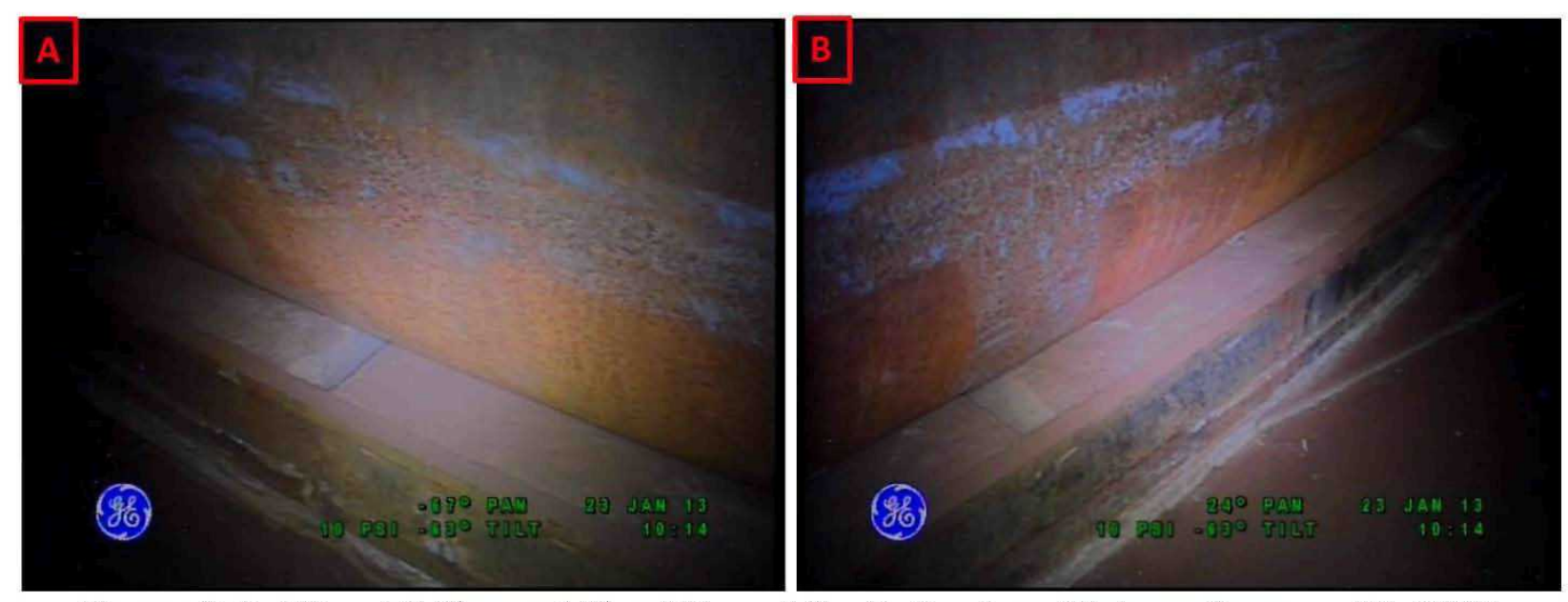

Figure 3-9. Riser 79 General Condition of the Refractory Slots on January 23, 2013

\subsubsection{Tank AZ-102 Riser 80}

Visual inspections performed through Riser 80 in 2007, 2011, and 2013 were compared and results are presented below.

\section{Tank Dome and Upper Haunch - Riser 80}

Figure 3-10 and Figure 3-11 show comparisons of the upper haunch area between inspections performed in 2007 and 2013. Since the camera was lower in the 2007 inspection, it is difficult to make any comparisons with the 2013 inspection of the top knuckle area. The camera was also at this lower position in the 2011 inspection. However, there appears to be no significant changes in the condition of this area from 2007 to 2013. No areas of interest were identified in the top knuckle region during the 2013 inspection. 


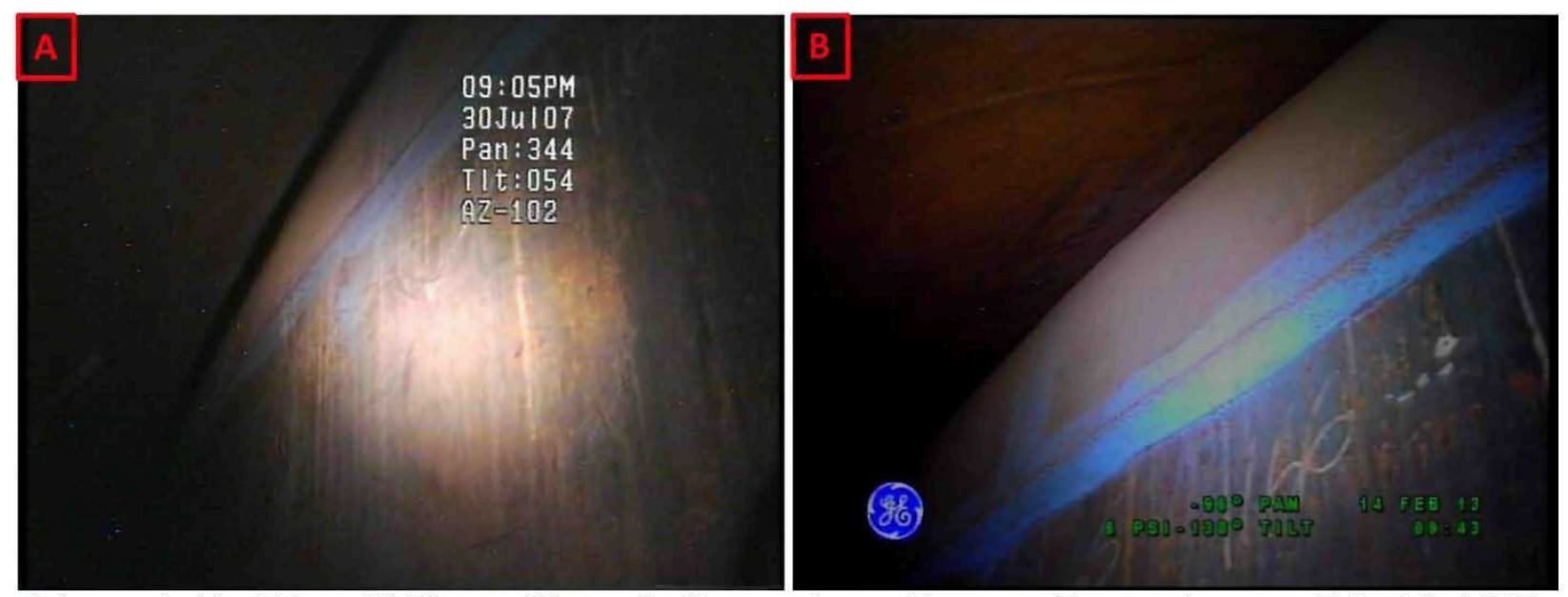

Figure 3-10. Riser 80 Upper Haunch Comparisons Between Inspections on July 30, 2007 (A) and February 14, 2013 (B) Looking Towards Riser 91
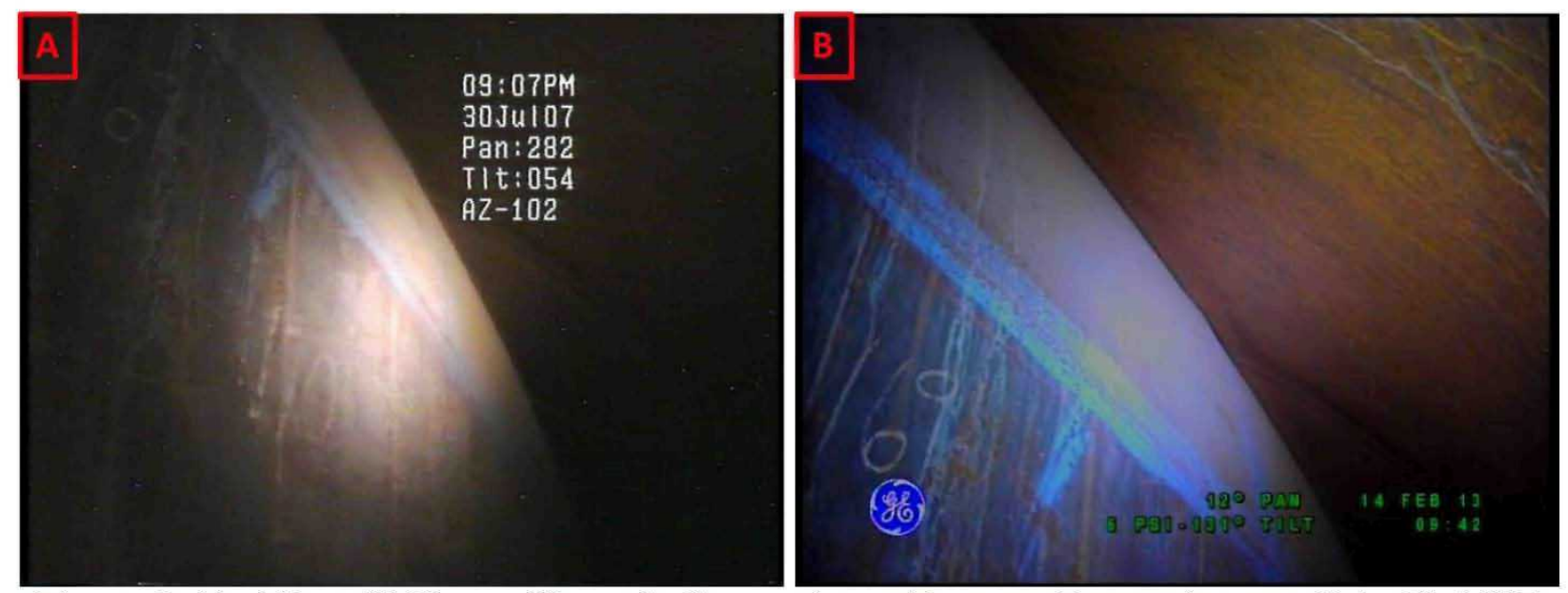

Figure 3-11. Riser 80 Upper Haunch Comparisons Between Inspections on July 30, 2007 (A) and February 14, 2013 (B) Looking Towards Riser 79

\section{Sidewall Comparison - Riser 80}

The sidewall of the primary tank appears to be in good condition and no areas of interest were identified on the primary tank sidewall during the 2013 inspection.

\section{Lower Knuckle and Annulus Floor Comparisons - Riser 80}

Figure 3-12 and Figure 3-13 show comparisons of the lower knuckle and annulus floor between inspections performed in 2007, 2011, and 2013 and between 2007 and 2013, respectively. There appears to be no significant change in the condition of this area between 2007 and 2013 . A beachline can also be seen along the annulus floor in Figure 3-12 and Figure 3-13 which is likely the result of evaporated couplant water used during UT examinations. In Figure 3-12, there is a distinct area on the annulus floor showing discoloration. This area is located under Riser 91, the location of the annulus leak detector ENRAF, which cannot be seen in this figure as the plummet was found to be suspended approximately 32 inches above the annulus floor (PER-2013-0274, AZ-102 Annulus Leak Detector ENRAF). This discoloration is likely to be the result of the 
annulus ENRAF installation in December 2003 (see Section 4.0 for additional details).

Unfortunately, no previous inspections viewed this area prior to 2007 to provide further insight. This anomaly does not appear to be a region of concern. Figure 3-14 shows the general condition of the refractory slots in 2007 and 2013 and no anomalies were noted. No anomalies were identified on the lower knuckle of the primary tank, insulating refractory, refractory slots, stiffener ring, or annulus floor during the 2013 inspection.

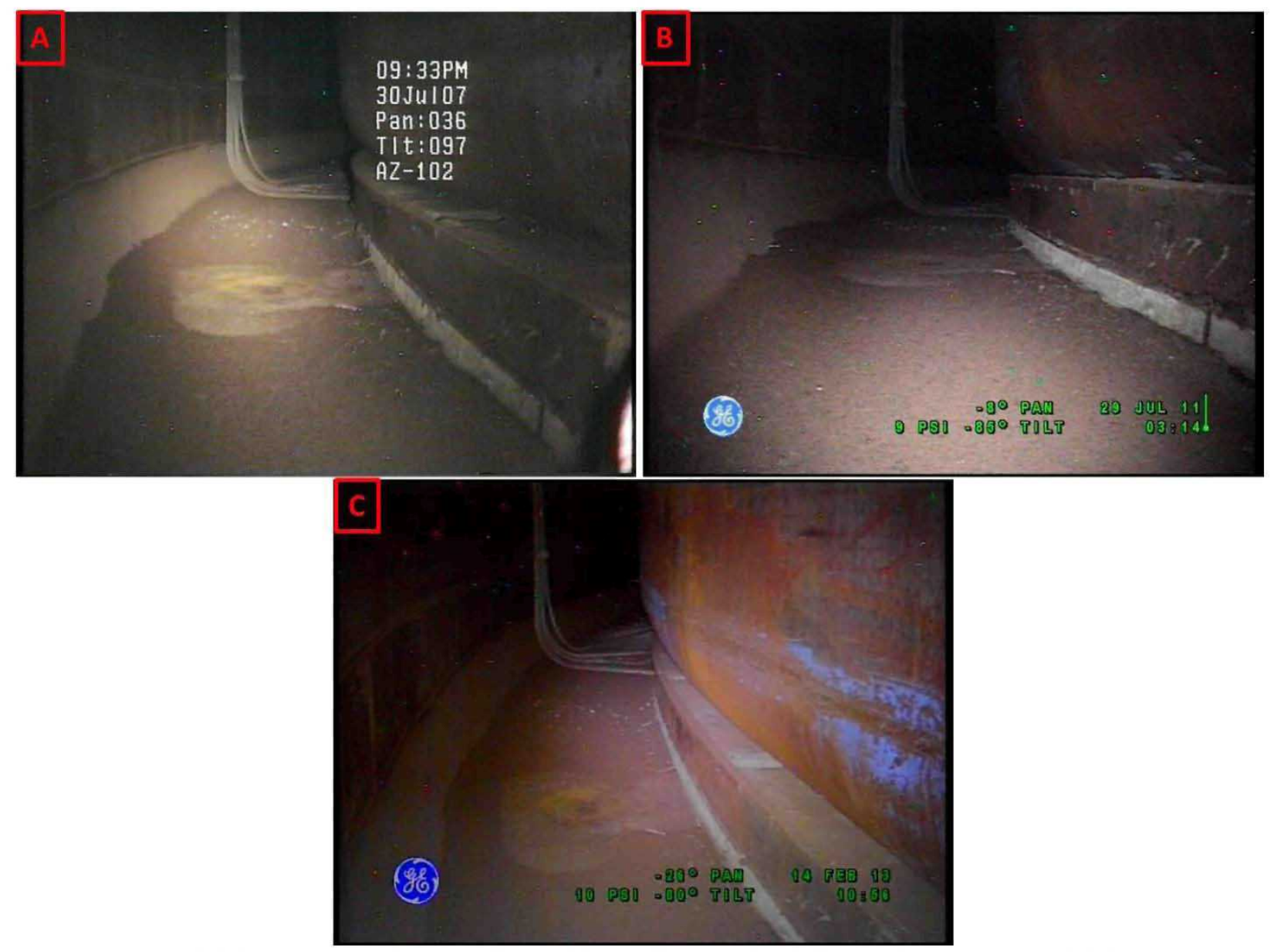

Figure 3-12. Riser 80 Lower Knuckle and Annulus Floor Comparisons Between Inspections on July 30, 2007 (A), July 29, 2011 (B), and February 14, 2013 (C) Looking Towards Riser 91 


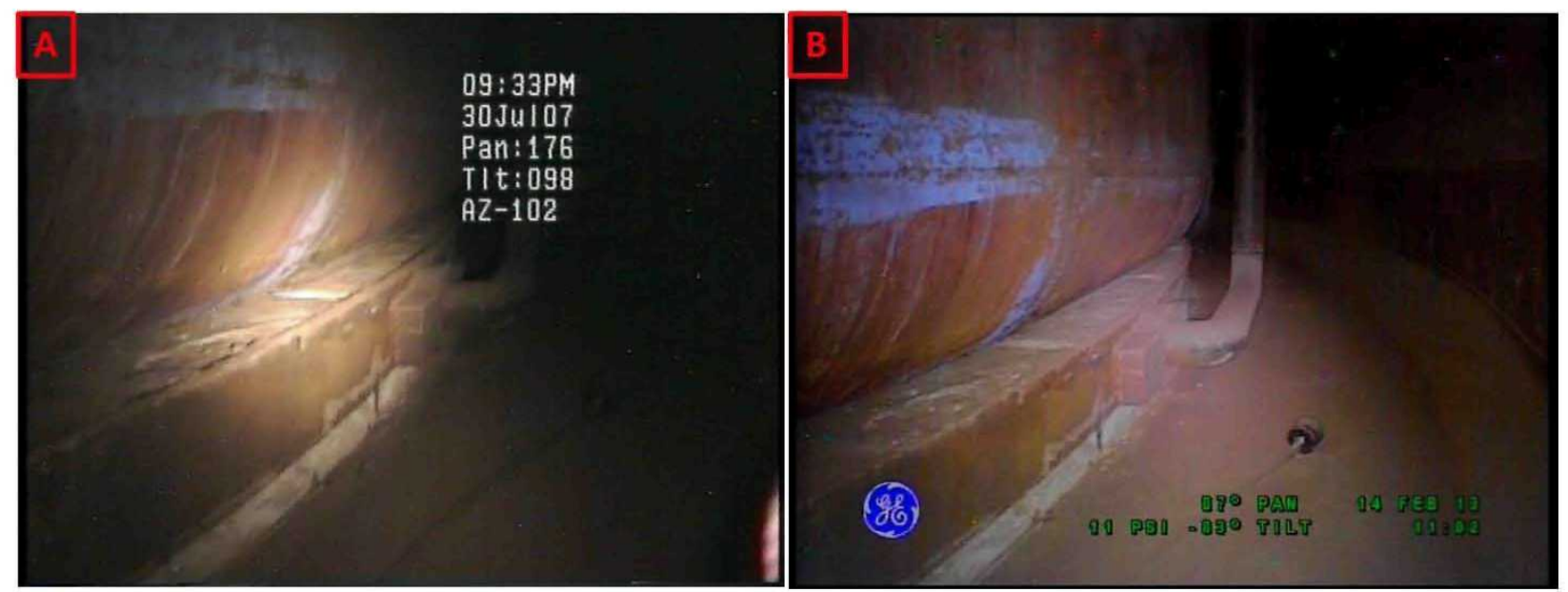

Figure 3-13. Riser 80 Lower Knuckle and Annulus Floor Comparisons Between Inspections on July 30, 2007 (A) and February 14, 2013 (B) Looking Towards Riser 79

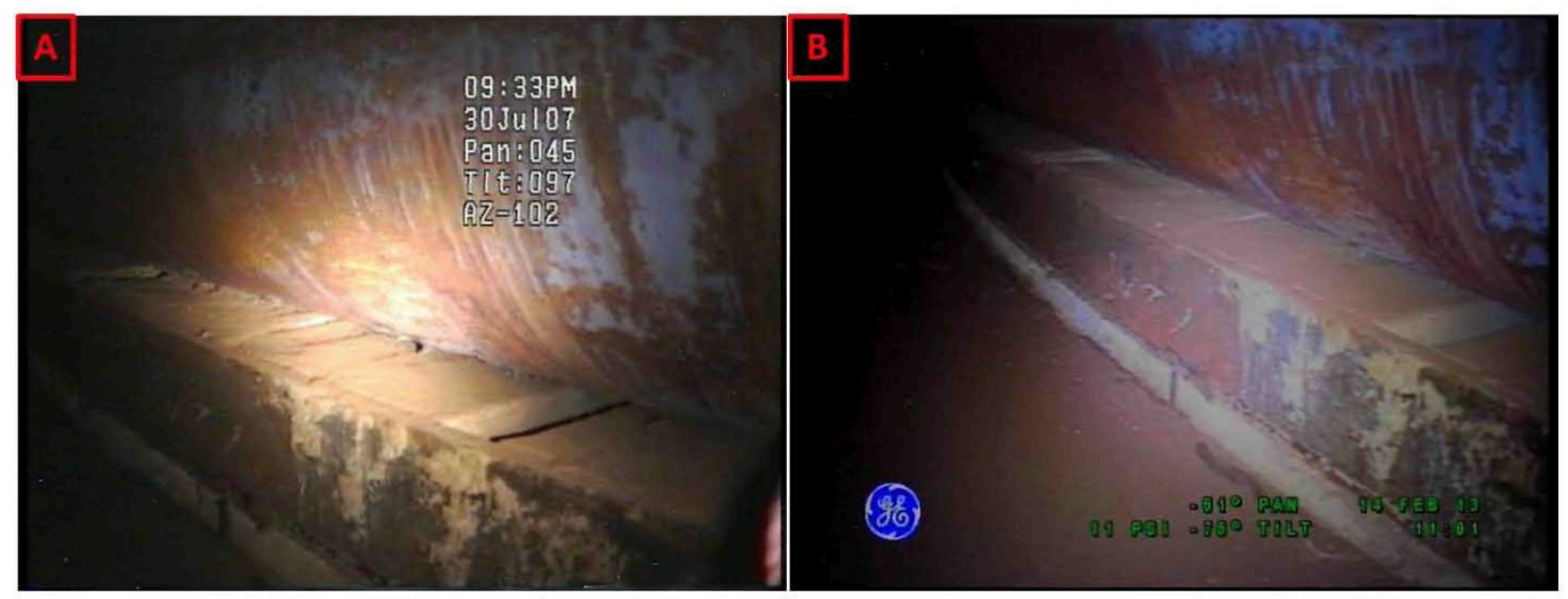

Figure 3-14. Riser 80 General Condition of the Refractory Slots on July 30, 2007 (A) and February 14, 2013 (B)

\subsubsection{Tank AZ-102 Riser 81}

Visual inspection results performed through Riser 81 in 2013 are presented below. There were no previous inspections performed through Riser 81 for comparisons.

\section{Tank Dome and Upper Haunch - Riser 81}

Figure 3-15 shows the general condition of the upper haunch area in January 2013. No areas of interest were identified in the top knuckle region during the 2013 inspection. 


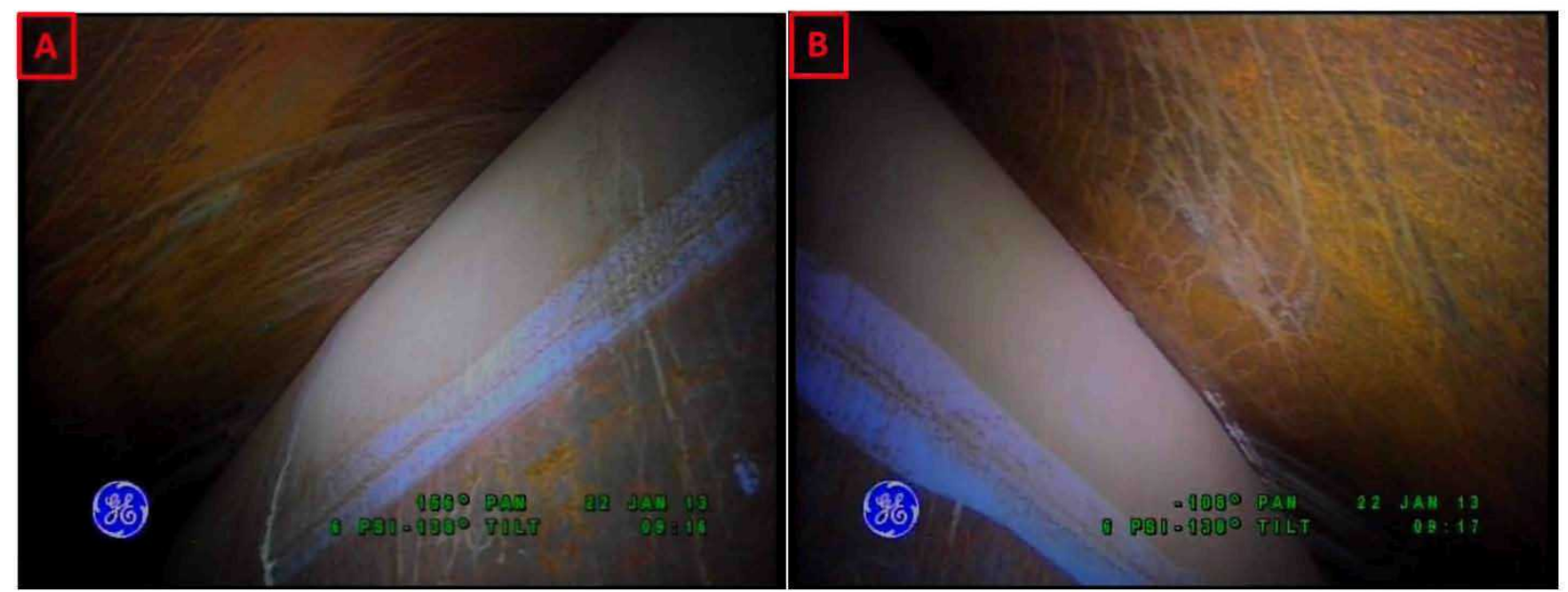

Figure 3-15. Riser 81 General Condition of the Upper Haunch on January 22, 2013 Looking Towards Riser 105 (A) and Looking Towards Riser 100 (B)

\section{Sidewall Comparison - Riser 81}

The sidewall of the primary tank appears to be in good condition and no areas of interest were identified on the primary tank sidewall during the 2013 inspection.

\section{Lower Knuckle and Annulus Floor Comparisons - Riser 81}

Figure 3-16 shows the general condition the lower knuckle and annulus floor in January 2013. In Figure 3-16B, there appears to be some unknown white debris along the annulus floor. The location of the white debris appears to match a small amount of white debris at the top of the secondary top knuckle. No previous inspections were performed in Riser 81 for comparison; however, white material does not appear to be coming from the primary tank. A beachline can also be seen along the annulus floor in Figure 3-16 which is likely the result of evaporated couplant water used during UT examinations. Figure 3-17 shows the general condition of the refractory slots in 2013 and no anomalies were noted. No anomalies were identified on the lower knuckle of the primary tank, insulating refractory, refractory slots, stiffener ring, or annulus floor during the 2013 inspection. 

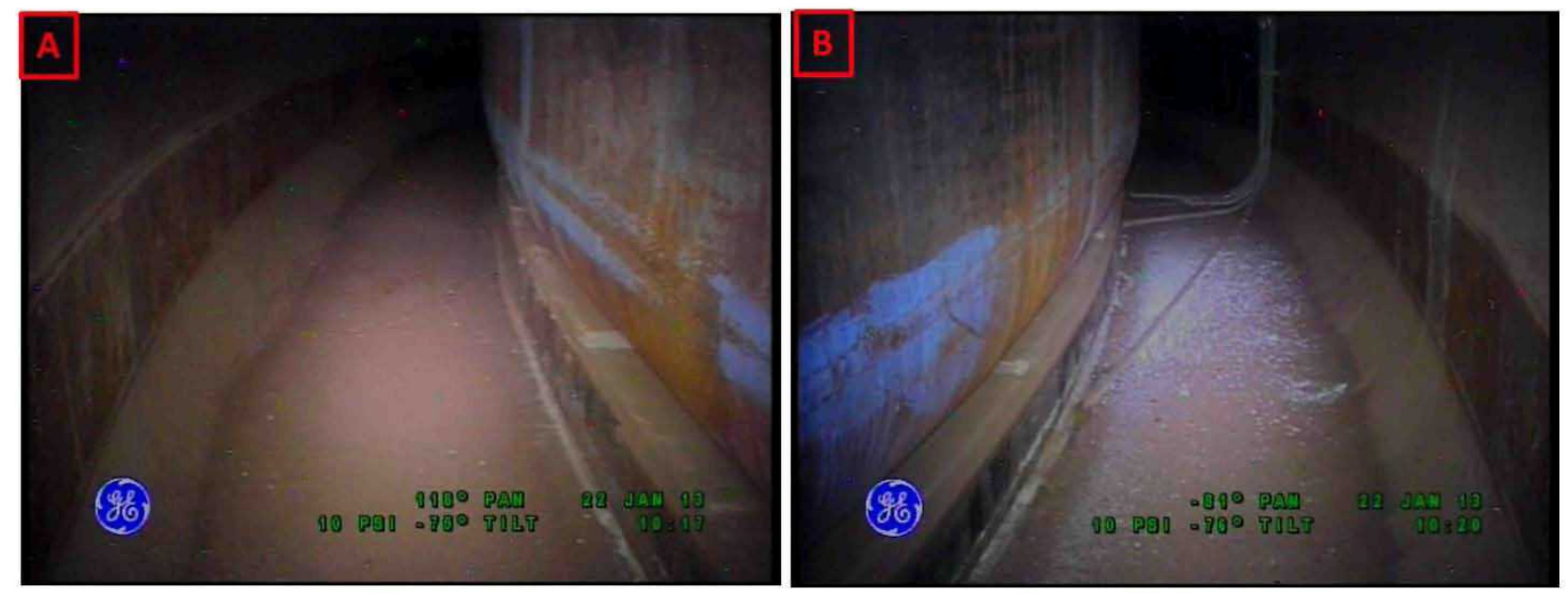

Figure 3-16. Riser 81 Lower Knuckle and Annulus Floor Condition on January 22, 2013 Looking Towards Riser 105 (A) and Looking Towards Riser 100 (B)
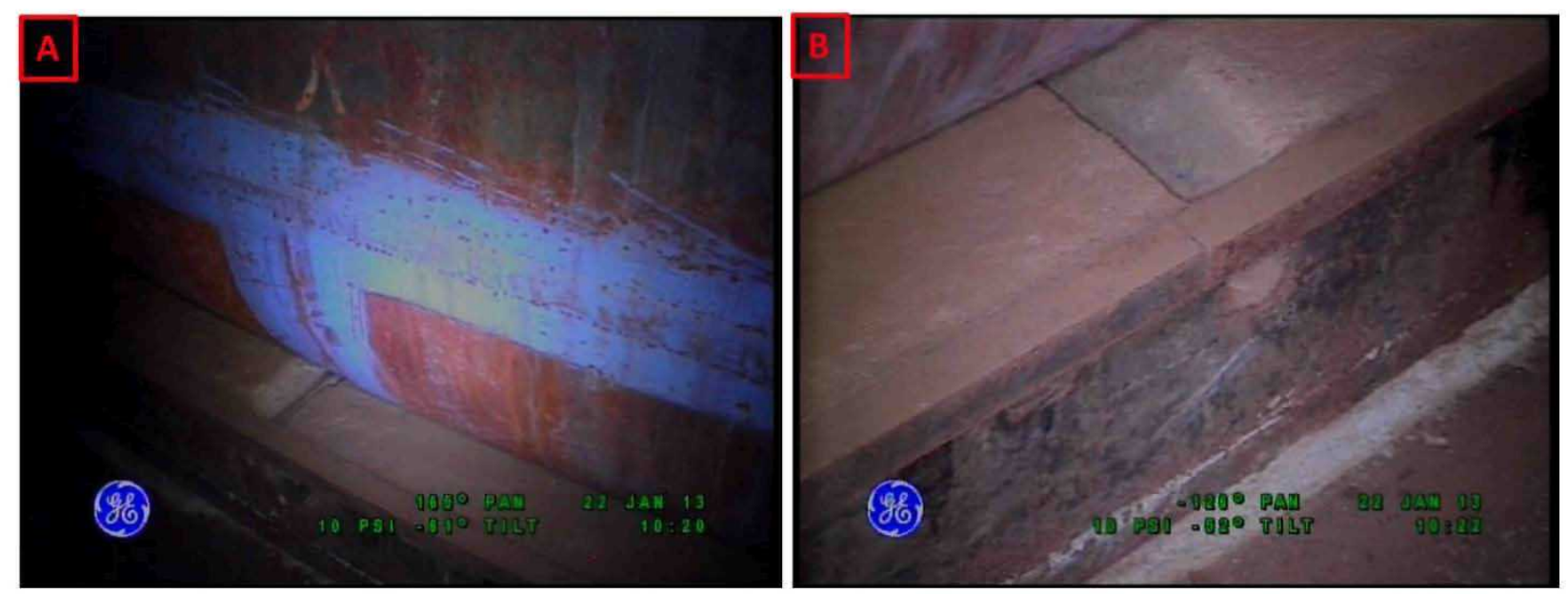

Figure 3-17. Riser 81 Lower Knuckle and Annulus Floor Condition on January 22, 2013

\subsubsection{Tank AZ-102 Riser 82}

Visual inspections performed through Riser 82 in 2001, 2011, and 2013 were compared and results are presented below.

\section{Tank Dome and Upper Haunch - Riser 82}

The tank dome and upper haunch area looking towards Riser 95 were not visible during the 2001 or 2011 inspection. Figure 3-18A and Figure 3-18B show comparisons of the upper haunch area looking towards Riser 105 between inspections performed in 2001 and 2013. There were no significant changes in the condition of this area from 2001 to 2013. No areas of interest were identified in the top knuckle region during the 2013 inspection. 


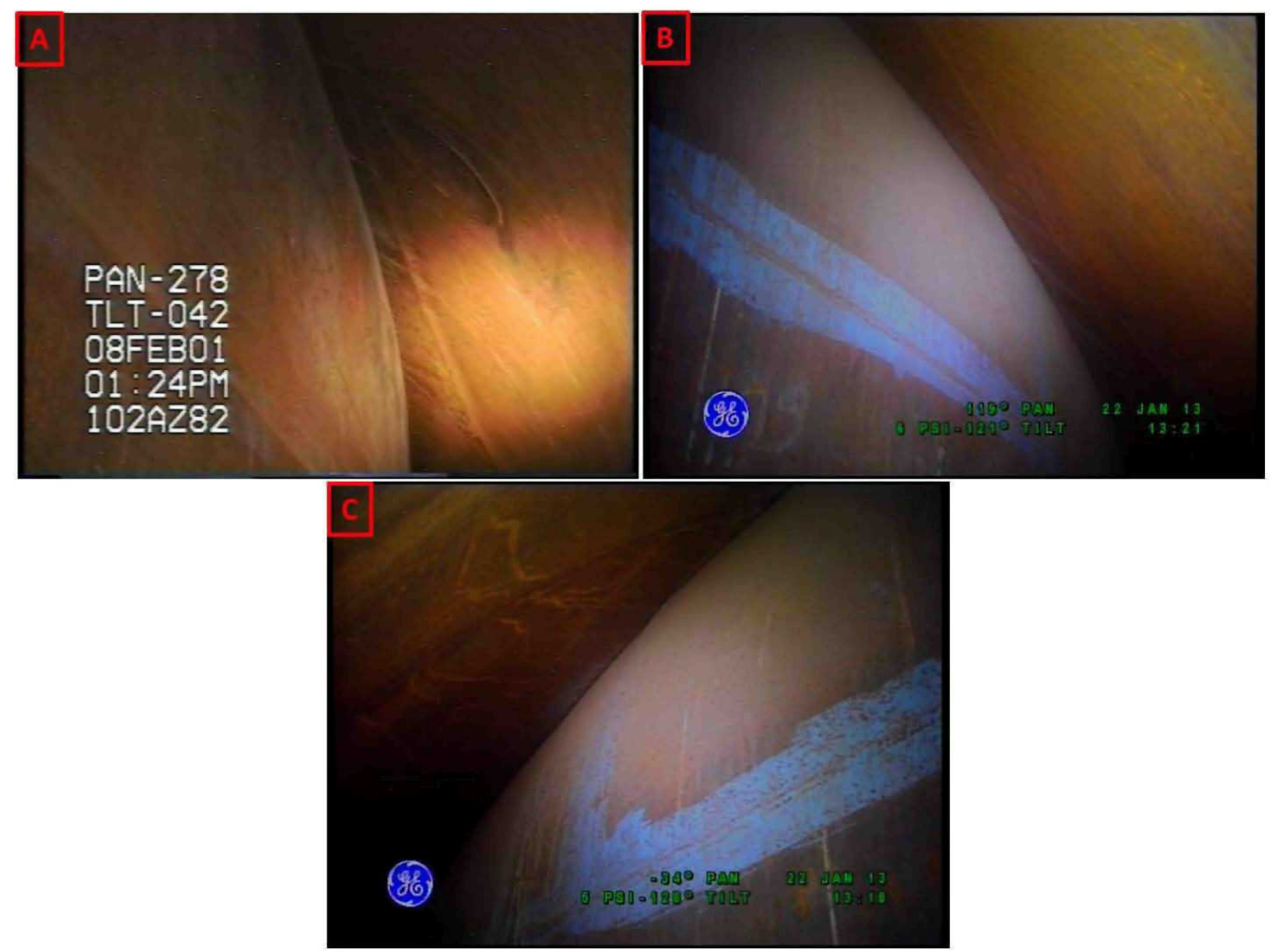

Figure 3-18. Riser 82 Upper Haunch Comparisons Between Inspections on February 8, 2001 (A) and January 22, 2013 (B) Looking Towards Riser 105 and on January 22, 2013 Looking Towards Riser 95 (C)

\section{Sidewall Comparison - Riser 82}

The sidewall of the primary tank appears to be in good condition and no areas of interest were identified on the primary tank sidewall during the 2013 inspection.

\section{Lower Knuckle and Annulus Floor Comparisons - Riser 82}

Figure 3-19 and Figure 3-20 show comparisons of the lower knuckle and annulus floor between inspections performed in 2001 and 2013. There appears to be no significant change in the condition of this area between 2001 and 2013. Figure 3-21 shows the general condition of the refractory slots in 2013 and no anomalies were noted. No anomalies were identified on the lower knuckle of the primary tank, insulating refractory, refractory slots, stiffener ring, or annulus floor during the 2013 inspection. 

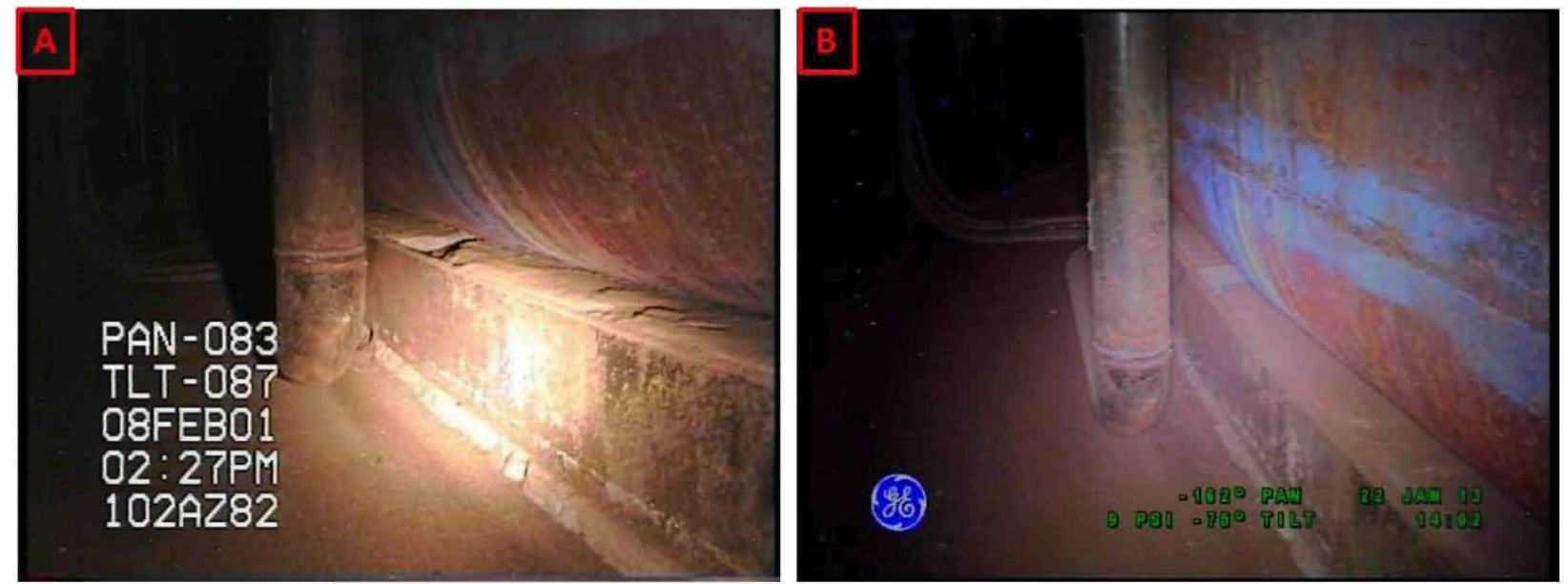

Figure 3-19. Riser 82 Lower Knuckle and Annulus Floor Comparisons Between Inspections on February 8, 2001 (A) and January 22, 2013 (B) Looking Towards Riser 95
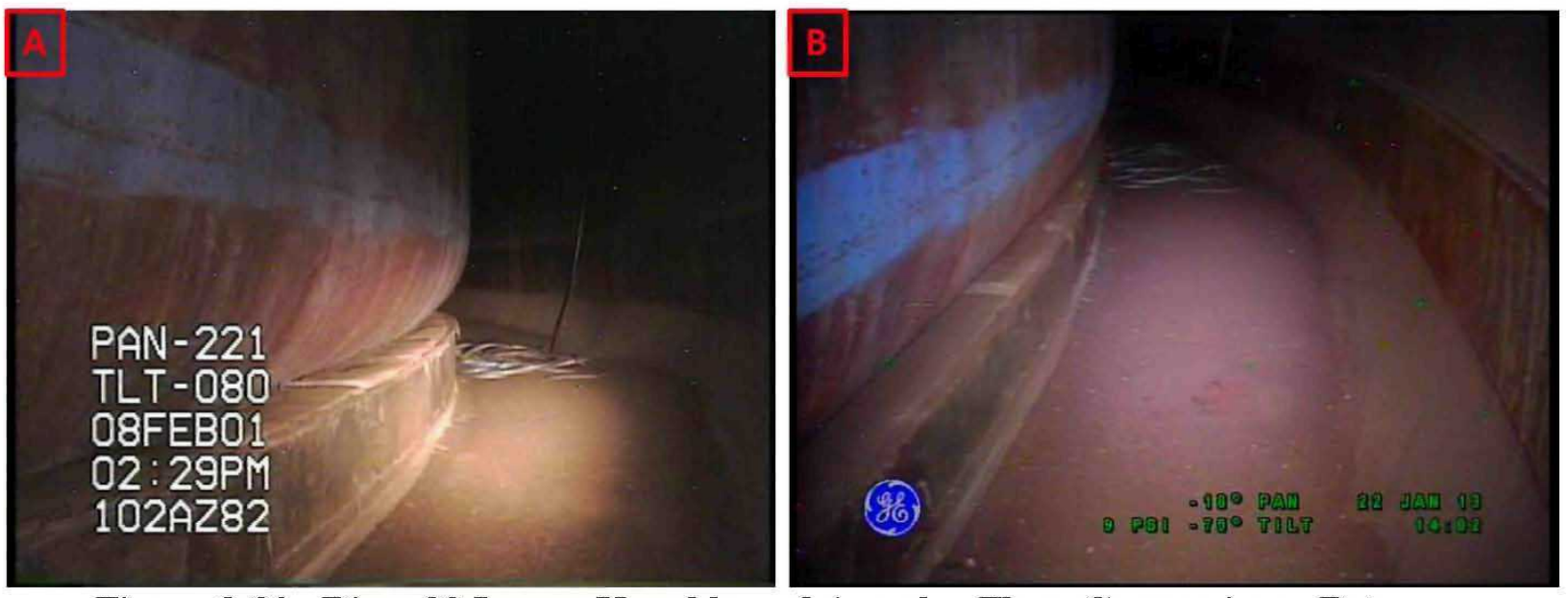

Figure 3-20. Riser 82 Lower Knuckle and Annulus Floor Comparisons Between Inspections on February 8, 2001 (A) and January 22, 2013 (B) Looking Towards Riser 105

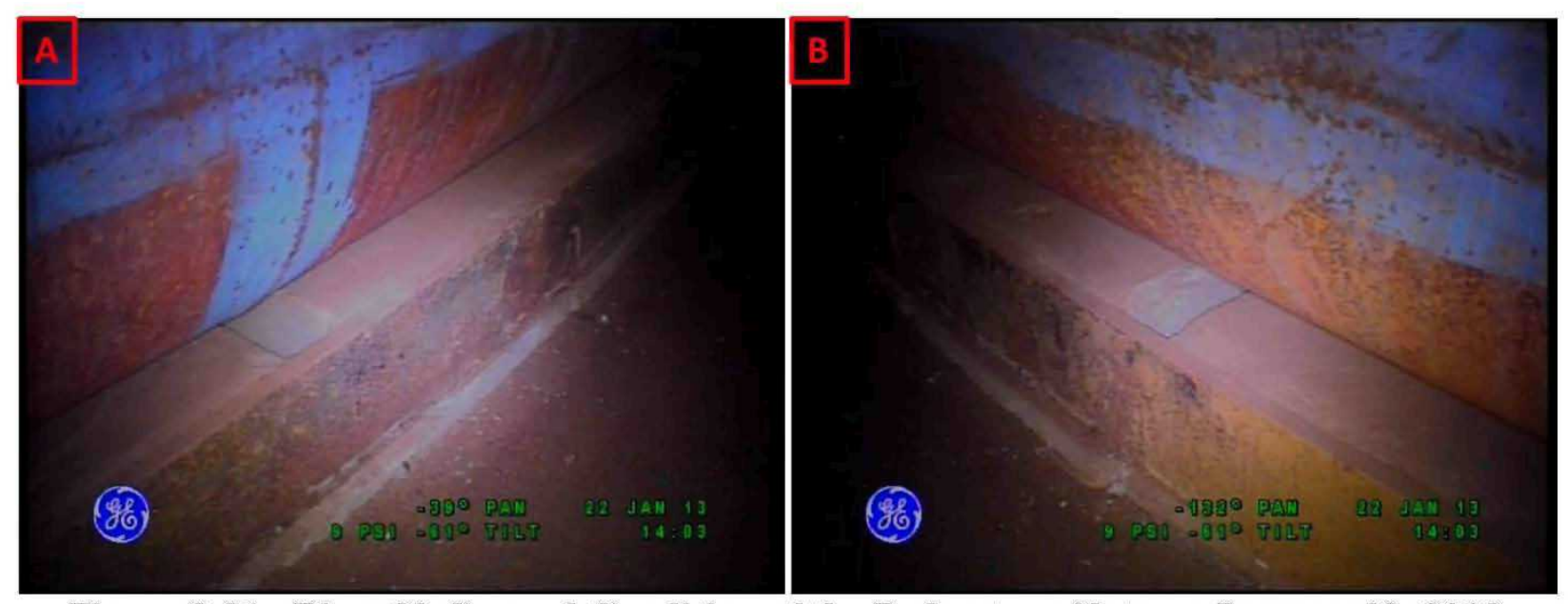

Figure 3-21. Riser 82 General Condition of the Refractory Slots on January 22, 2013 


\subsubsection{Tank AZ-102 Riser 83}

Visual inspection results performed through Riser 83 in 2013 are presented below. There were no previous inspections performed through Riser 83 for comparisons.

\section{Tank Dome and Upper Haunch - Riser 83}

Figure 3-22 shows the general condition of the upper haunch area in January 2013. In Figure 3-22A, white streaks can be seen on the primary tank. These white streaks, which are commonly seen among the DSTs, are referred to as laitance flow which can be attributed to the pouring of the concrete dome during construction. No areas of interest were identified in the top knuckle region during the 2013 inspection.
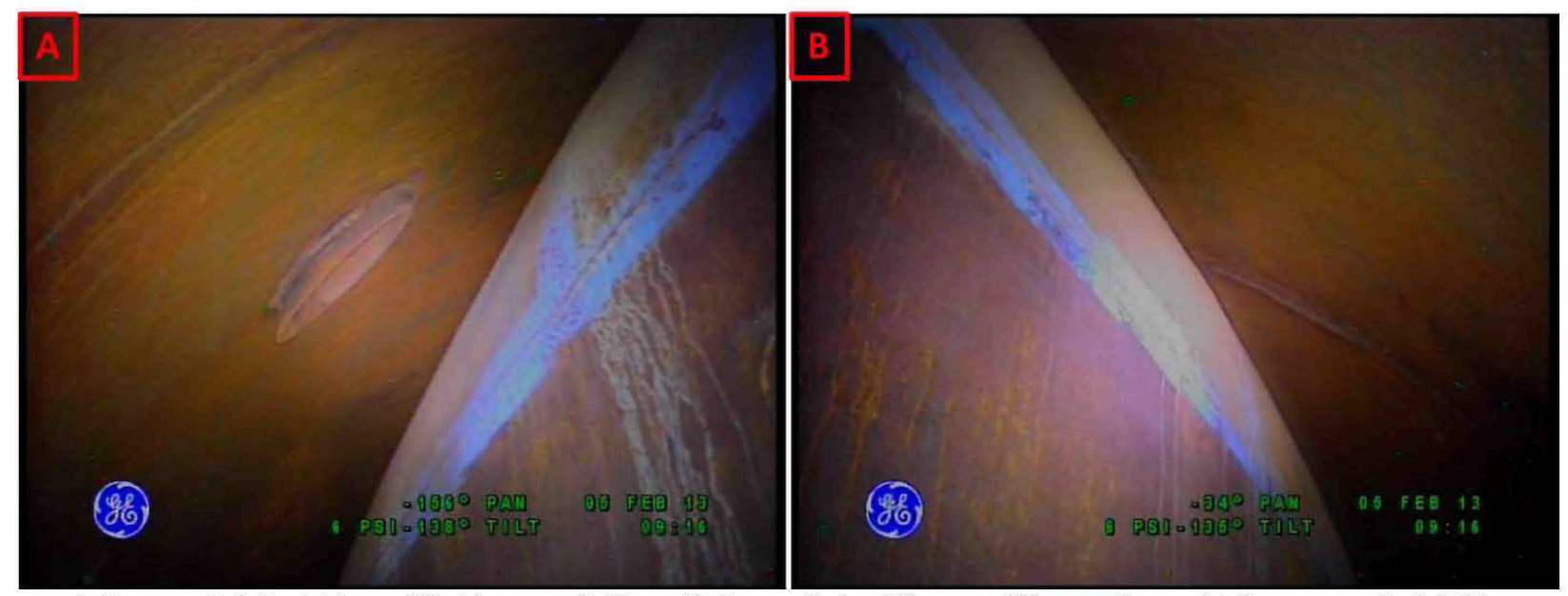

Figure 3-22. Riser 83 General Condition of the Upper Haunch on February 5, 2013 Looking Towards Riser 96 (A) and Looking Towards Riser 89 (B)

\section{Sidewall Comparison - Riser 83}

The sidewall of the primary tank appears to be in good condition and no areas of interest were identified on the primary tank sidewall during the 2013 inspection.

\section{Lower Knuckle and Annulus Floor Comparisons - Riser 83}

Figure 3-23 shows the general condition of the lower knuckle and annulus floor in January 2013. A beachline can also be seen along the annulus floor in Figure 3-23 which is likely the result of evaporated couplant water used during UT examinations. Figure 3-24 shows the general condition of the refractory slots in 2013 and no anomalies were noted. No anomalies were identified on the lower knuckle of the primary tank, insulating refractory, refractory slots, stiffener ring, or annulus floor during the 2013 inspection. 


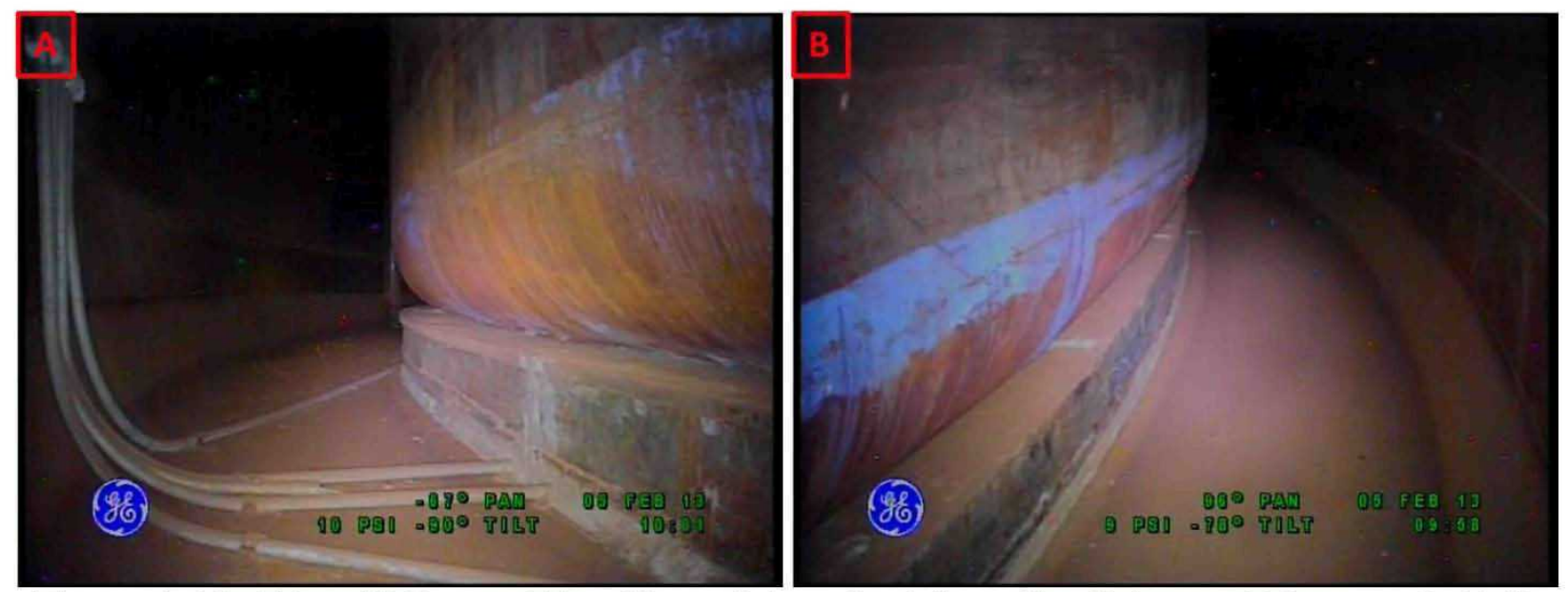

Figure 3-23. Riser 83 Lower Knuckle and Annulus Floor Condition on February 5, 2013 Looking Towards Riser 96 (A) and Looking Towards Riser 89 (B)

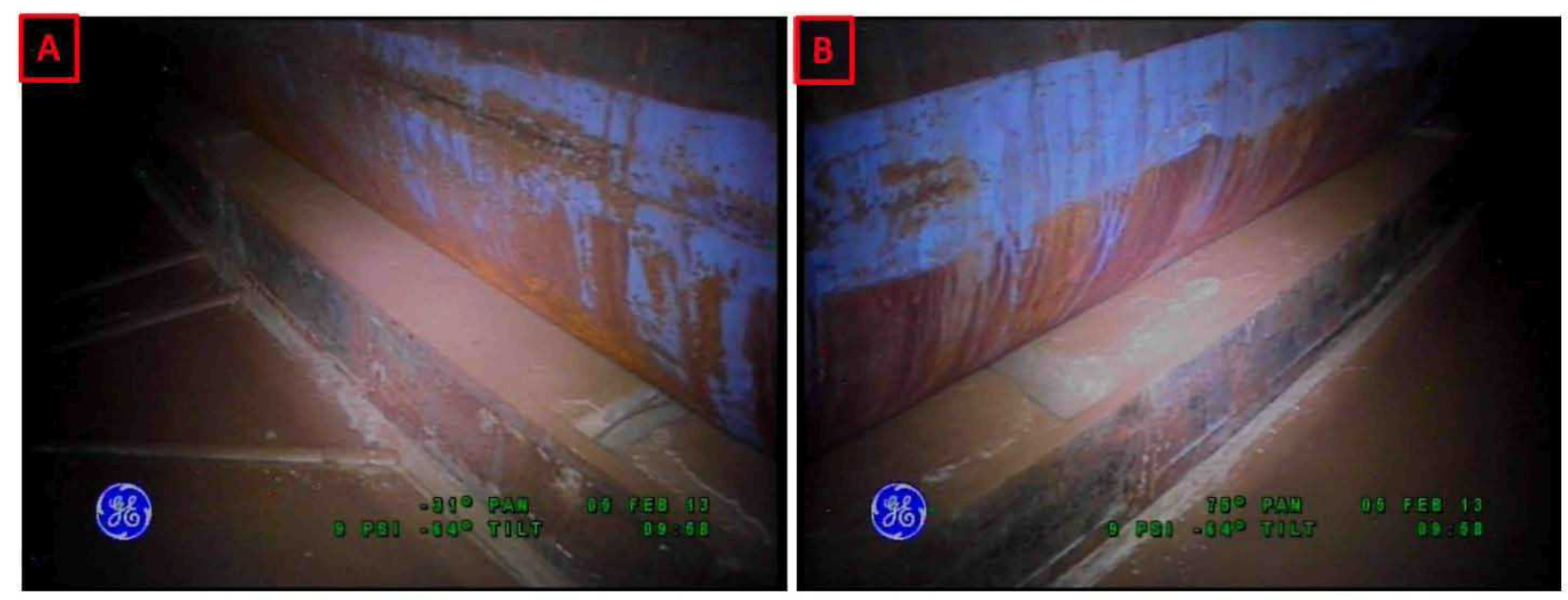

Figure 3-24. Riser 83 General Condition of the Refractory Slots on February 5, 2013

\subsubsection{Tank AZ-102 Riser 84}

Visual inspections performed through Riser 84 in 1993,2001, and 2013 were compared and results are presented below.

\section{Tank Dome and Upper Haunch - Riser 84}

The tank dome and upper haunch area were not visible during the 1993 and 2001 inspections. Figure 3-25 shows the general condition of the upper haunch area in February 2013. No areas of interest were identified in the top knuckle region during the 2013 inspection. 


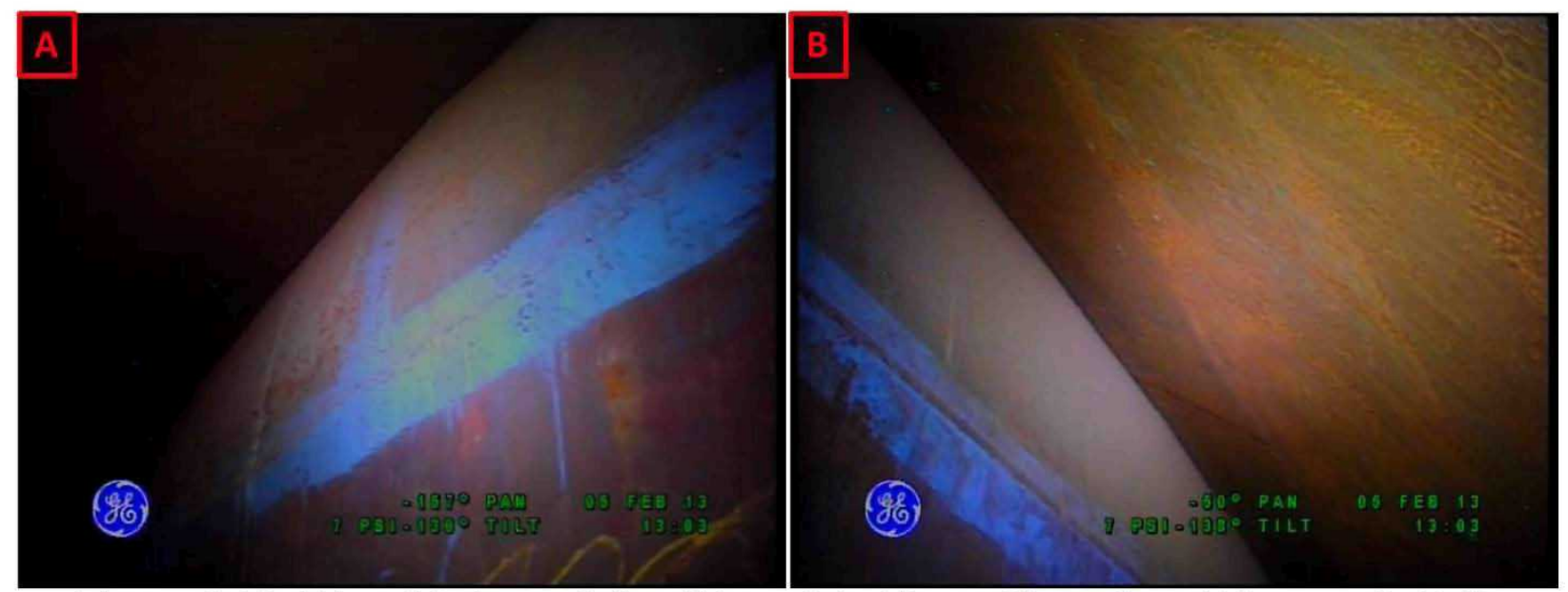

Figure 3-25. Riser 84 General Condition of the Upper Haunch on February 5, 2013 Looking Towards Riser 85 (A) and Looking Towards Riser 102 (B)

\section{Sidewall Comparison - Riser 84}

The sidewall of the primary tank appears to be in good condition and no areas of interest were identified on the primary tank sidewall during the 2013 inspection.

\section{Lower Knuckle and Annulus Floor Comparisons - Riser 84}

Figure 3-26 and Figure 3-27 show comparisons of the lower knuckle and annulus floor between inspections performed in 1993 and 2013. There appears to be no significant change in the condition of this area between 1993 and 2013. A beachline can also be seen along the annulus floor in Figure 3-27 which is likely the result of evaporated couplant water used during UT examinations. Figure 3-28 shows the general condition of the refractory slots in February 2013 and no anomalies were noted. No anomalies were identified on the lower knuckle of the primary tank, insulating refractory, refractory slots, stiffener ring, or annulus floor during the 2013 inspection.
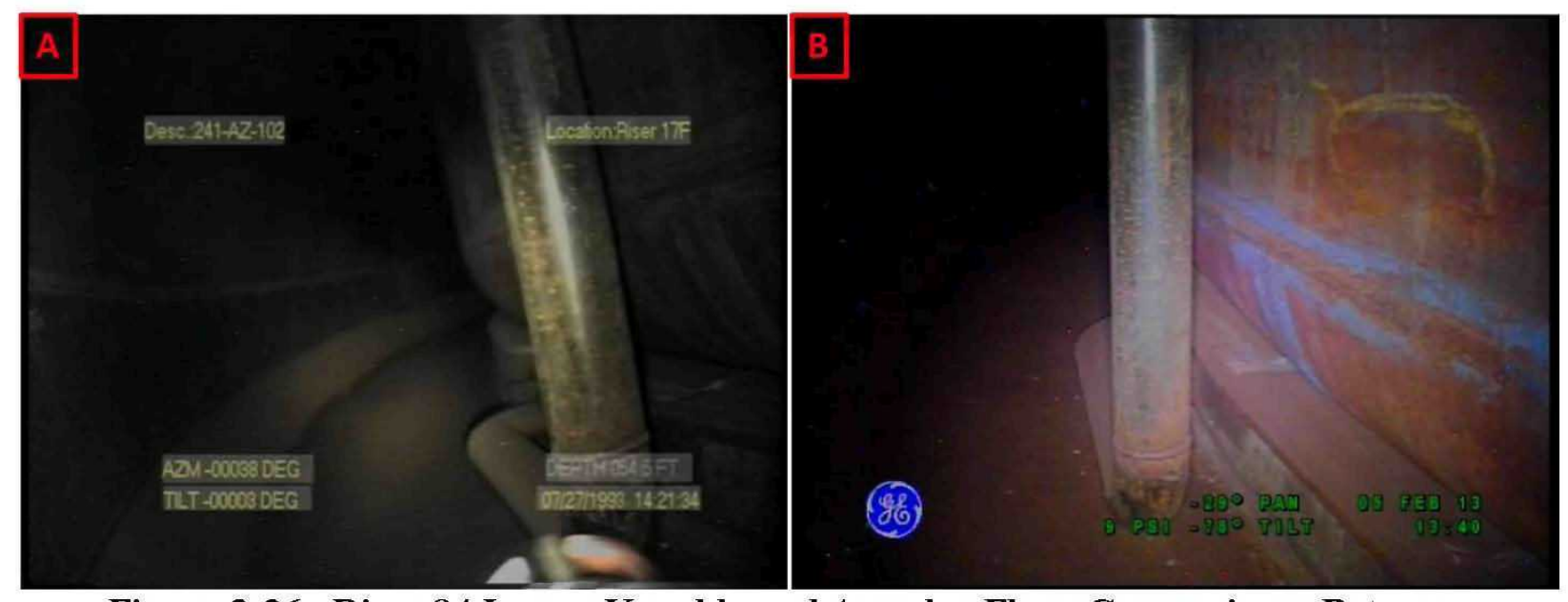

Figure 3-26. Riser 84 Lower Knuckle and Annulus Floor Comparisons Between Inspections on July 27, 1993 (A) and February 5, 2013 (B) Looking Towards Riser 85 


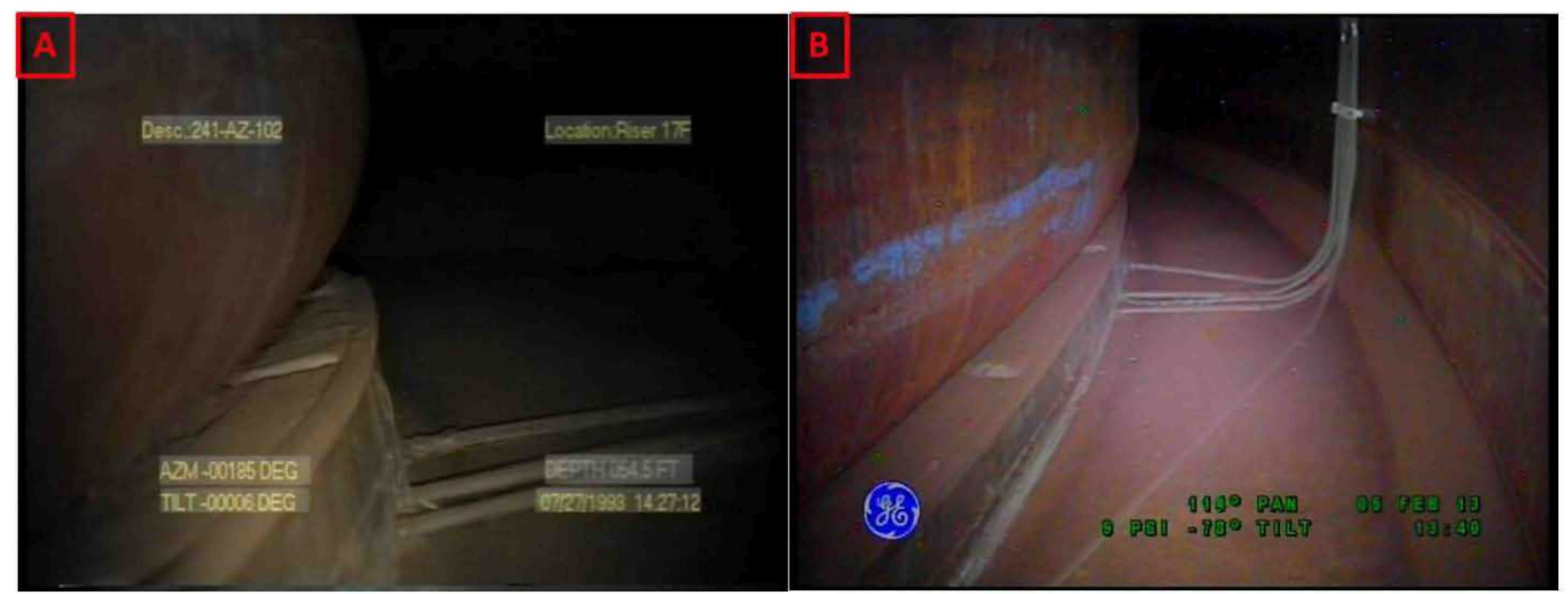

Figure 3-27. Riser 84 Lower Knuckle and Annulus Floor Comparisons Between Inspections on July 27, 1993 (A) and February 5, 2013 (B) Looking Towards Riser 102
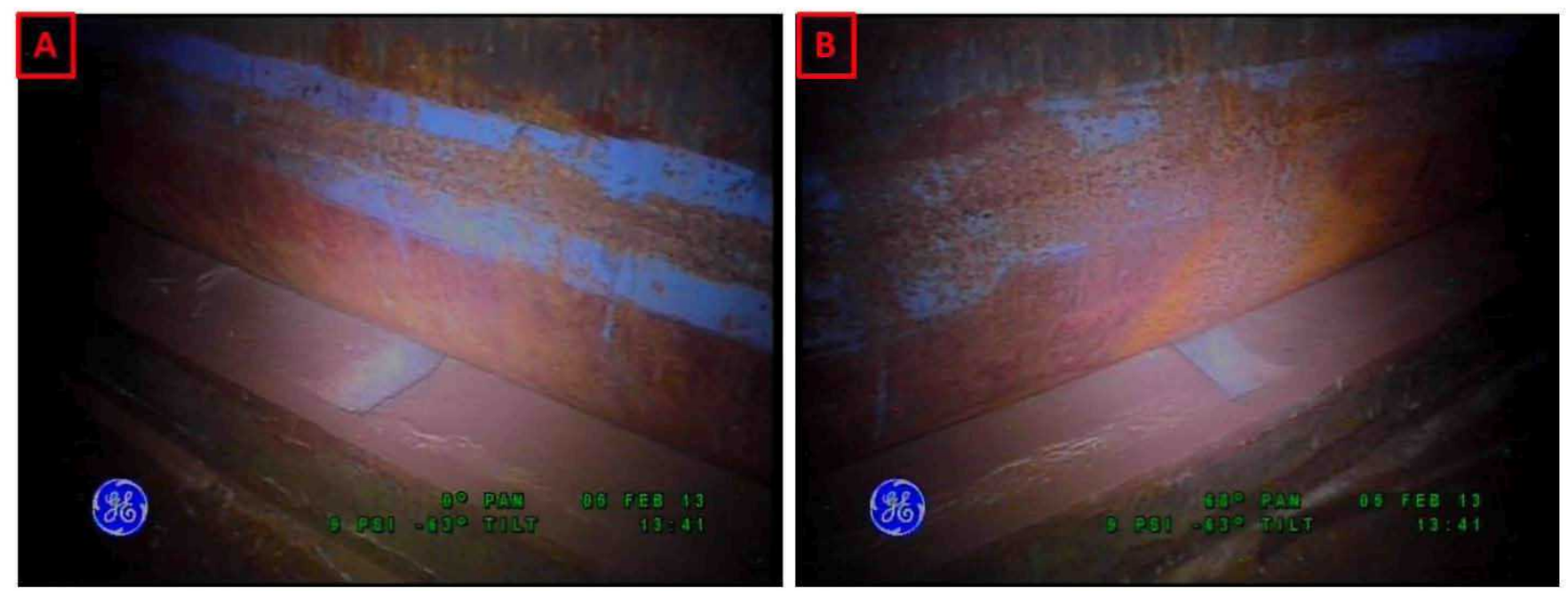

Figure 3-28. Riser 84 General Condition of the Refractory Slots on February 5, 2013

\subsubsection{Tank AZ-102 Riser 86}

Visual inspections results performed through Riser 86 in 2013 are presented below. There were no previous inspections performed through Riser 86 for comparisons.

\section{Tank Dome and Upper Haunch - Riser 86}

Figure 3-29 shows the general condition of the upper haunch area in January 2013. In Figure 3-29A, white streaks can be seen on the primary tank. These white streaks, which are commonly seen among the DSTs, are referred to as laitance flow attributed to the pouring of the concrete dome during construction. No areas of interest were identified in the top knuckle region during the 2013 inspection. 

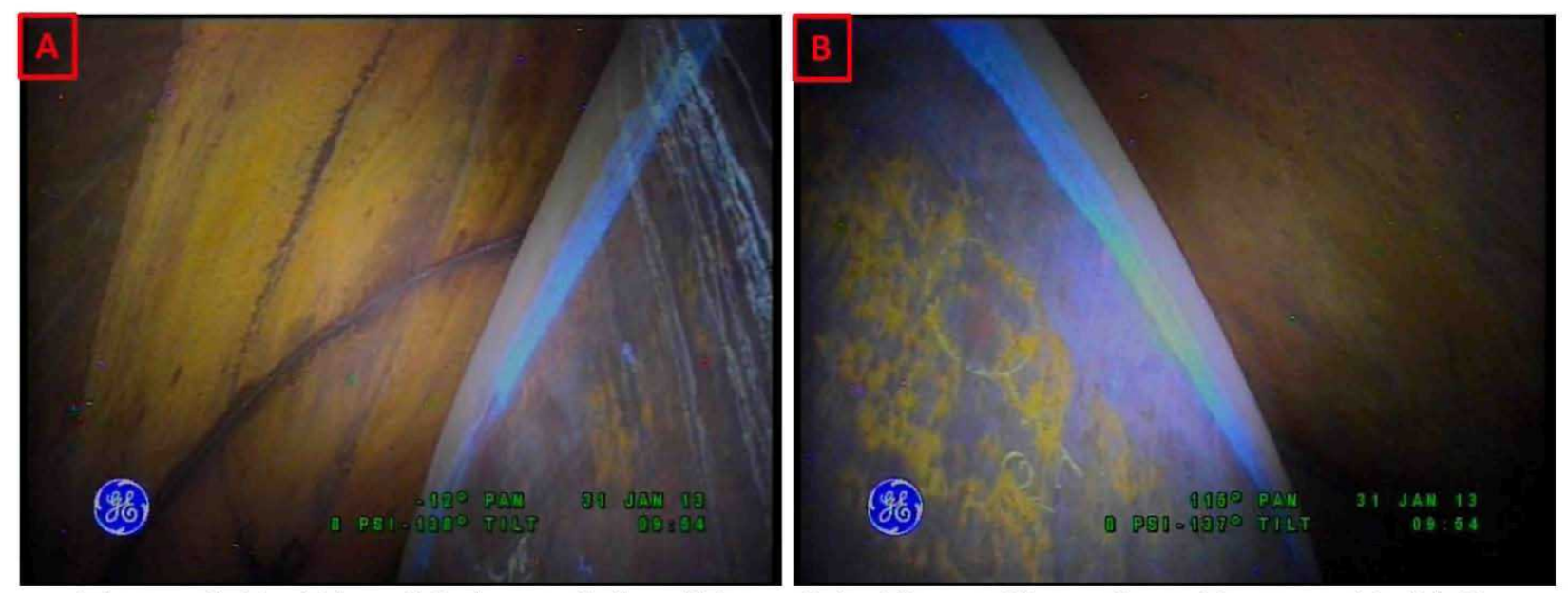

Figure 3-29. Riser 86 General Condition of the Upper Haunch on January 31, 2013 Looking Towards Riser 87 (A) and Looking Towards Riser 103 (B)

\section{Sidewall Comparison - Riser 86}

The sidewall of the primary tank appears to be in good condition and no areas of interest were identified on the primary tank sidewall during the 2013 inspection.

\section{Lower Knuckle and Annulus Floor Comparisons - Riser 86}

Figure 3-30 shows the general condition of the lower knuckle and annulus floor in January 2013. Figure 3-31 shows the general condition of the refractory slots in January 2013 and no anomalies were noted. No anomalies were identified on the lower knuckle of the primary tank, insulating refractory, refractory slots, stiffener ring, or annulus floor during the 2013 inspection.

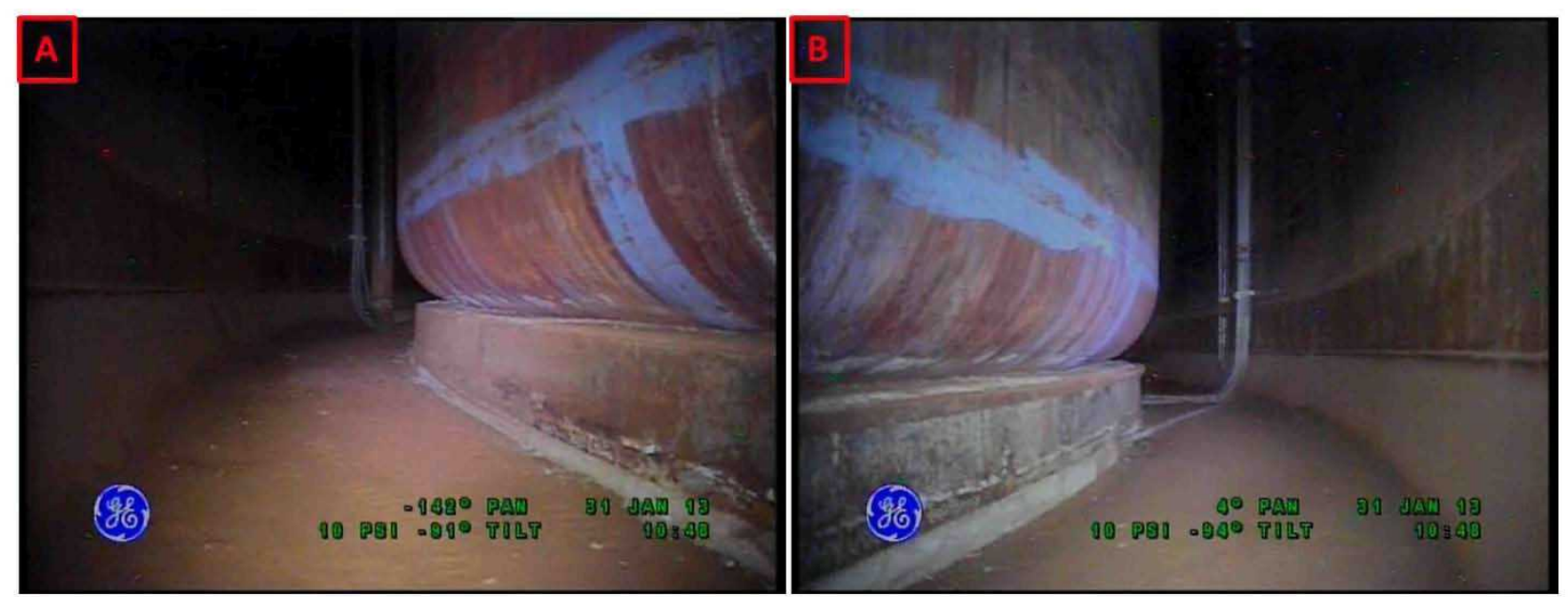

Figure 3-30. Riser 86 Lower Knuckle and Annulus Floor Condition on January 31, 2013 Looking Towards Riser 87 (A) and Looking Towards Riser 103 (B) 

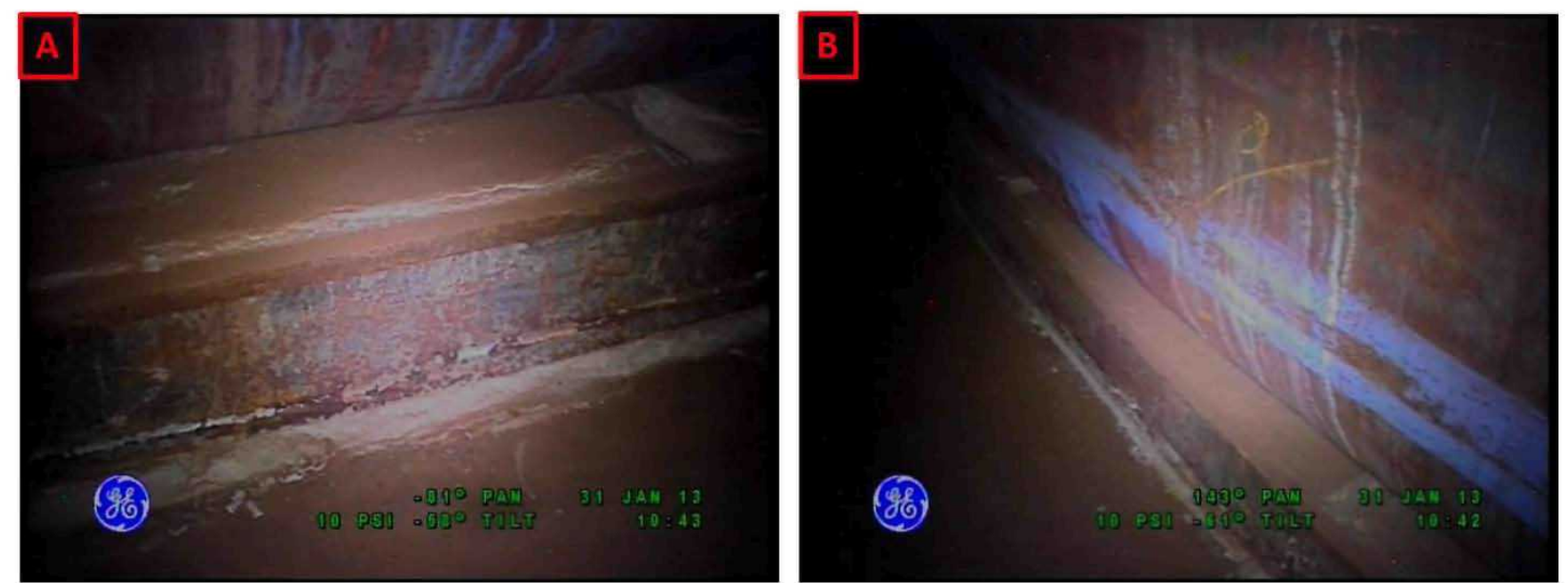

Figure 3-31. Riser 86 General Condition of the Refractory Slots on January 31, 2013

\subsubsection{Tank AZ-102 Riser 88}

Visual inspection results performed through Riser 88 in 2013 are presented below. There were no previous inspections performed through Riser 88 for comparisons.

\section{Tank Dome and Upper Haunch - Riser 88}

Figure 3-32 shows the general condition of the upper haunch area in January 2013. No areas of interest were identified in the top knuckle region during the 2013 inspection.
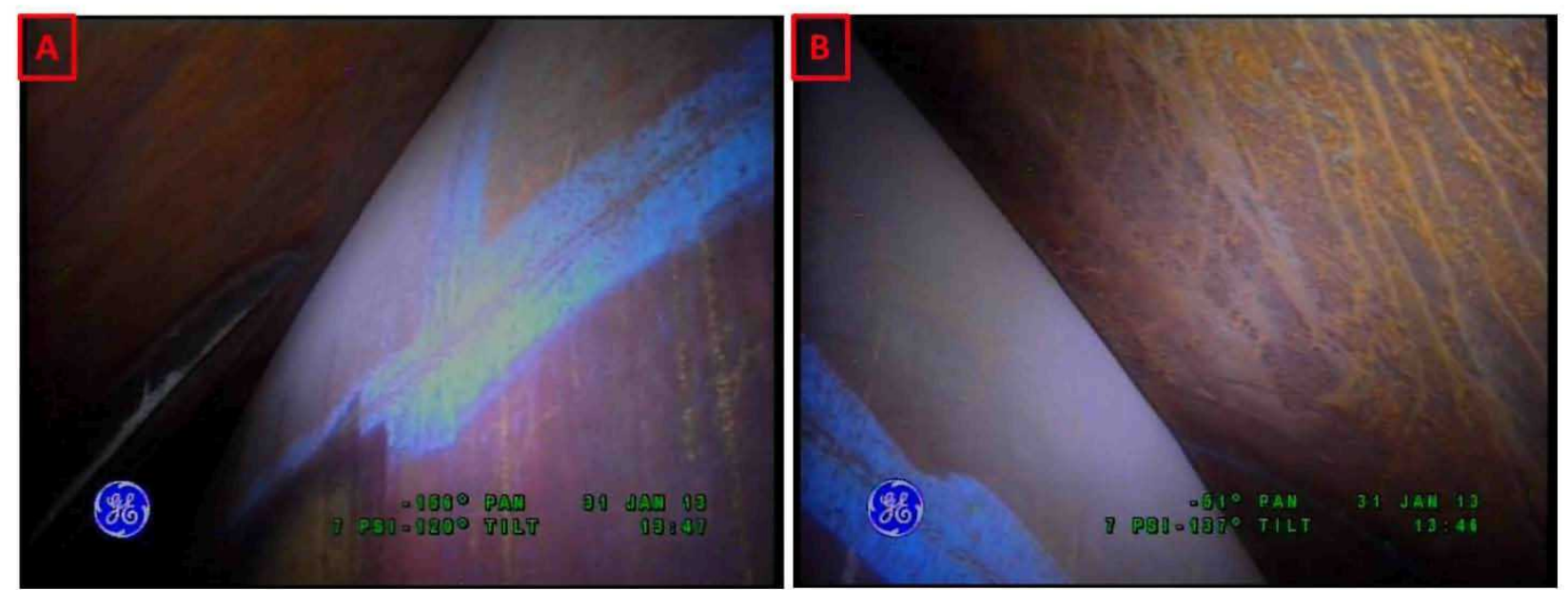

Figure 3-32. Riser 88 General Condition of the Upper Haunch on January 31, 2013 Looking Towards Riser 90 (A) and Looking Towards Riser 104 (B)

\section{Sidewall Comparison - Riser 88}

The sidewall of the primary tank appears to be in good condition and no areas of interest were identified on the primary tank sidewall during the 2013 inspection. 


\section{Lower Knuckle and Annulus Floor Comparison - Riser 88}

Figure 3-33 shows the general condition of the lower knuckle and annulus floor in January 2013. The stains on the annulus floor shown in Figure 3-33A are likely from the UT examinations that were performed in nearby Riser 90 . Figure 3-34 shows the general condition of the refractory slots in January 2013 and no anomalies were noted. No anomalies were identified on the lower knuckle of the primary tank, insulating refractory, refractory slots, stiffener ring, or annulus floor during the 2013 inspection.

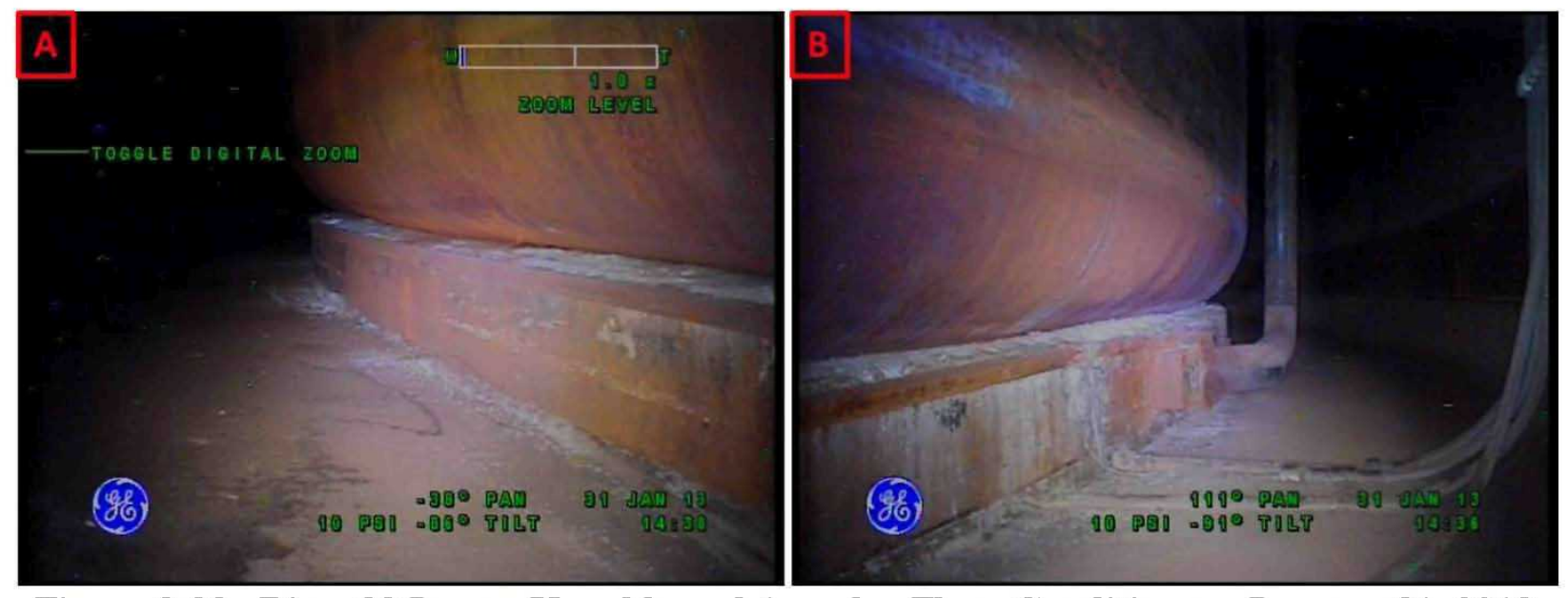

Figure 3-33. Riser 88 Lower Knuckle and Annulus Floor Condition on January 31, 2013 Looking Towards Riser 90 (A) and Looking Towards Riser 104 (B)
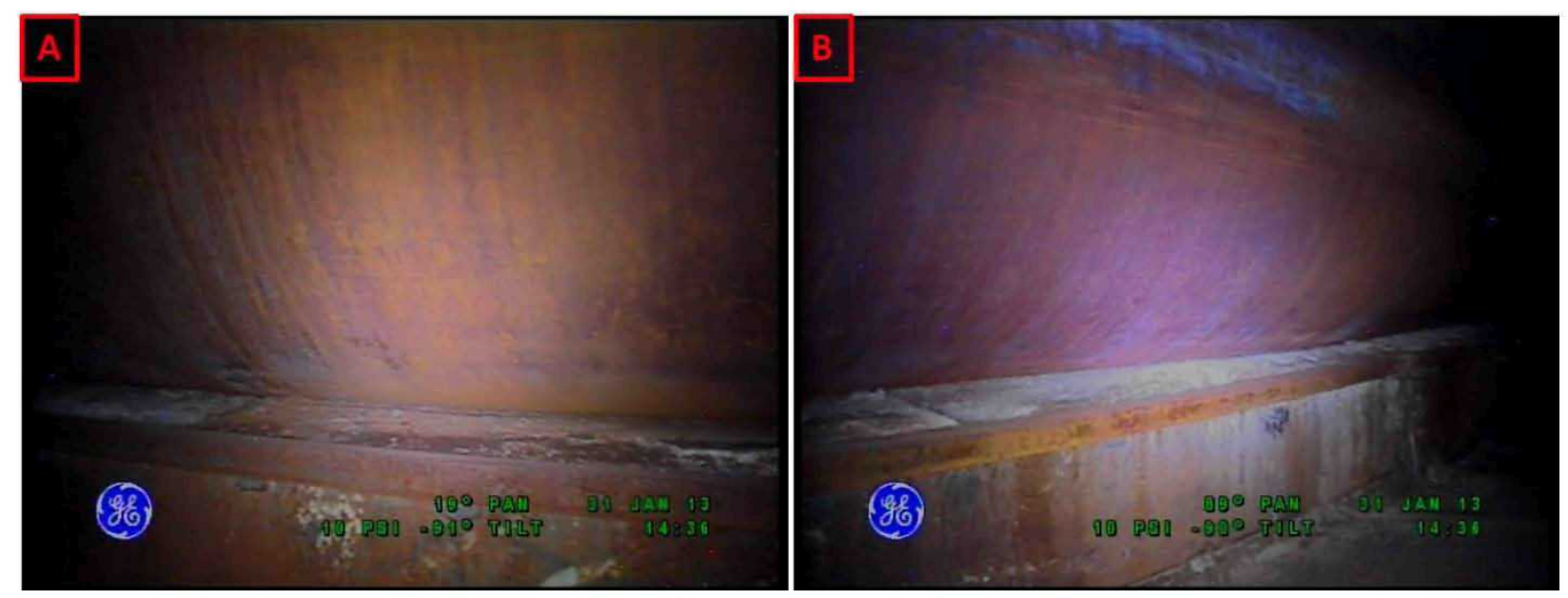

Figure 3-34. Riser 88 General Condition of the Refractory Slots on January 31, 2013

\subsubsection{Tank AZ-102 Riser 89}

Visual inspection results performed through Riser 89 in 2013 are presented below. There were no previous inspections performed through Riser 89 for comparisons. 


\section{Tank Dome and Upper Haunch - Riser 89}

Figure 3-35 shows the general condition of the upper haunch area in February 2013. No areas of interest were identified in the top knuckle region during the 2013 inspection.
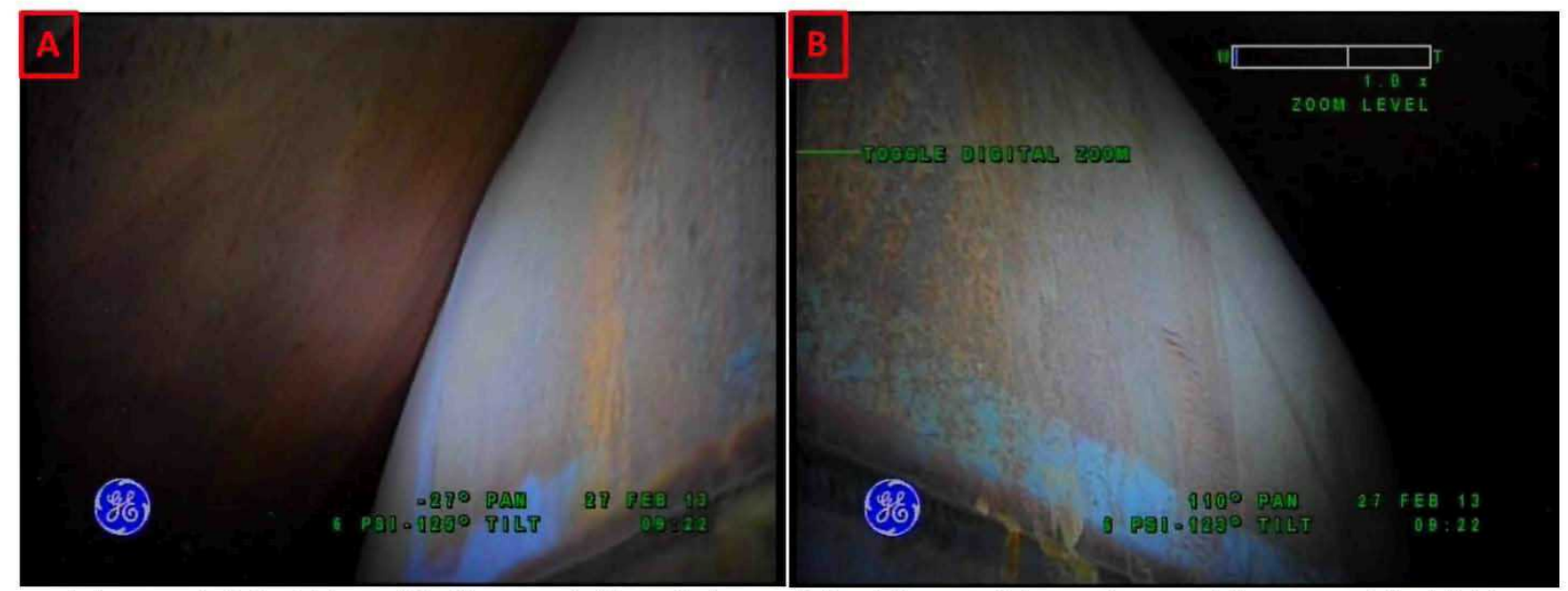

Figure 3-35. Riser 89 General Condition of the Upper Haunch on February 27, 2013 Looking Towards Riser 83 (A) and Looking Towards Riser 101 (B)

\section{Sidewall Comparison - Riser 89}

The sidewall of the primary tank appears to be in good condition and no areas of interest were identified on the primary tank sidewall during the 2013 inspection.

\section{Lower Knuckle and Annulus Floor Comparisons - Riser 89}

Figure 3-36 shows the general condition of the lower knuckle and annulus floor in February 2013. A beachline can also be seen along the annulus floor in Figure 3-36A which is likely the result of evaporated couplant water used during UT examinations. Figure 3-37 shows the general condition of the refractory slots in February 2013 and no anomalies were noted. No anomalies were identified on the lower knuckle of the primary tank, insulating refractory, refractory slots, stiffener ring, or annulus floor during the 2013 inspection. 


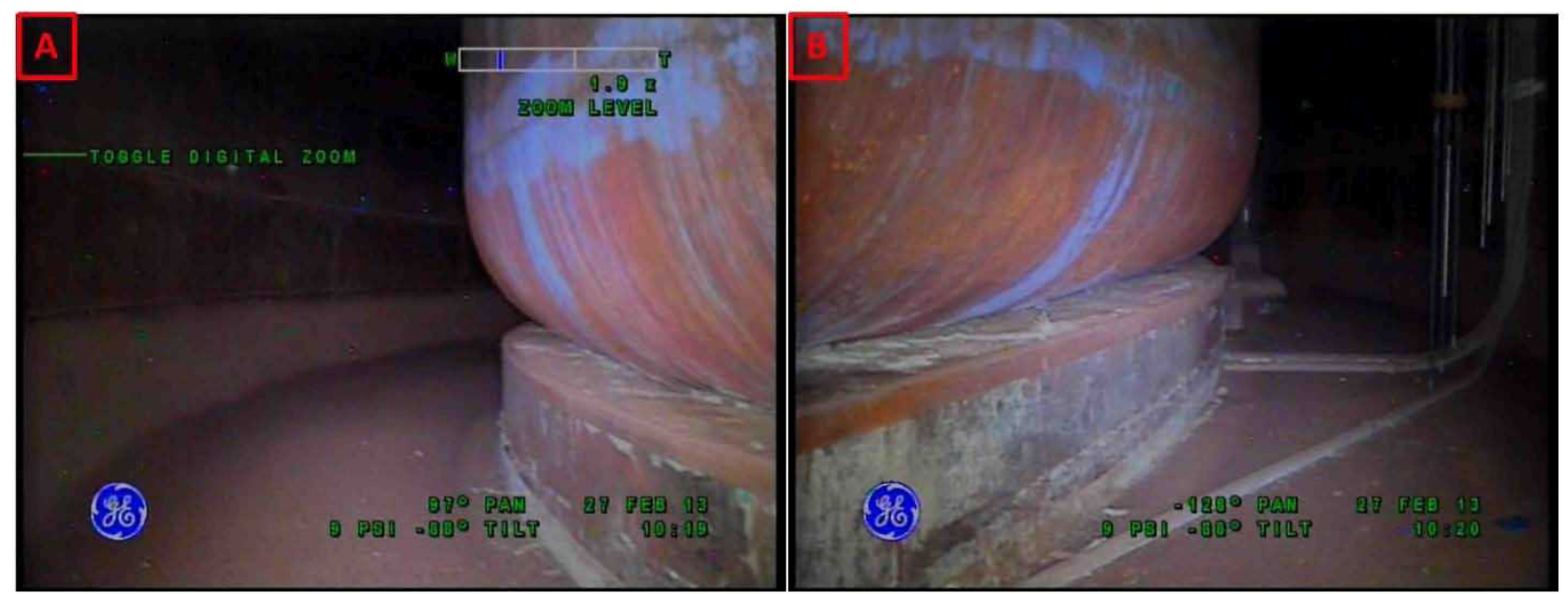

Figure 3-36. Riser 89 Lower Knuckle and Annulus Floor Condition on February 27, 2013 Looking Towards Riser 83 (A) and Looking Towards Riser 101 (B)

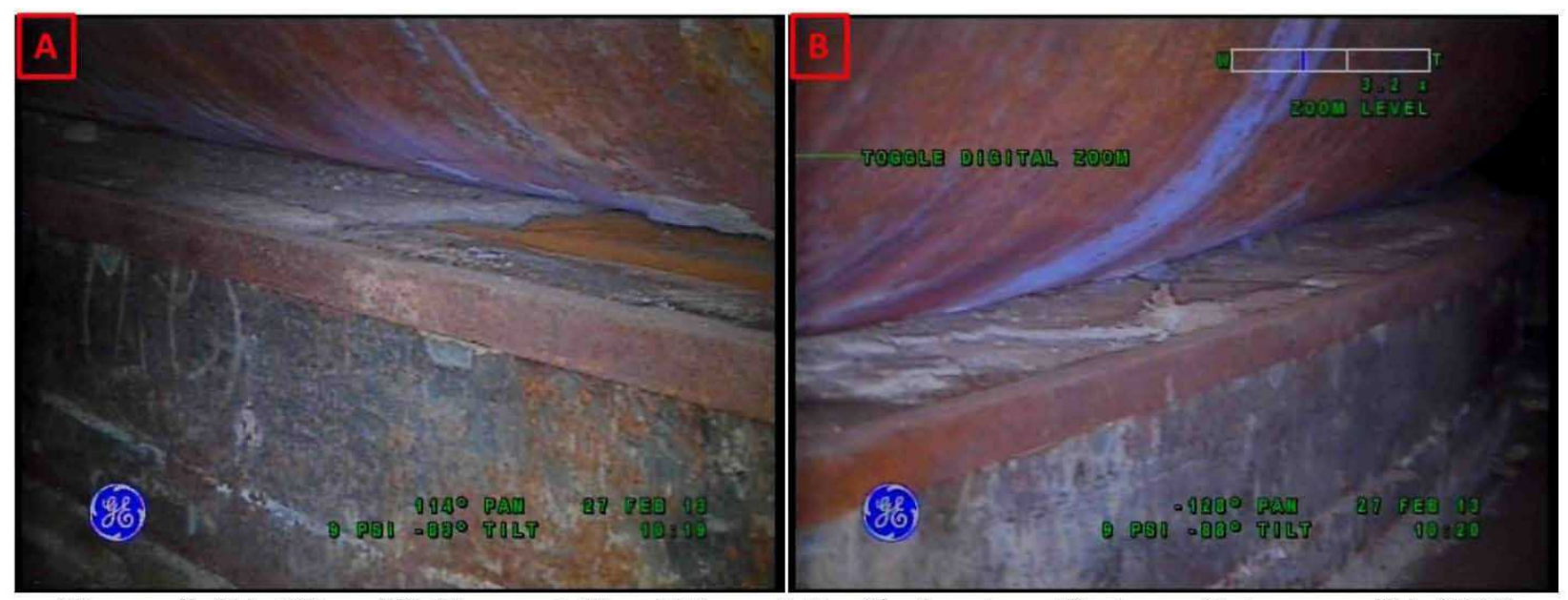

Figure 3-37. Riser 89 General Condition of the Refractory Slots on February 27, 2013

\subsubsection{Tank AZ-102 Riser 92}

Visual inspection results performed through Riser 92 in 2013 are presented below. There were no previous inspections performed through Riser 92 for comparisons.

\section{Tank Dome and Upper Haunch - Riser 92}

Figure 3-38 shows the general condition of the upper haunch area in February 2013. No areas of interest were identified in the top knuckle region during the 2013 inspection. 


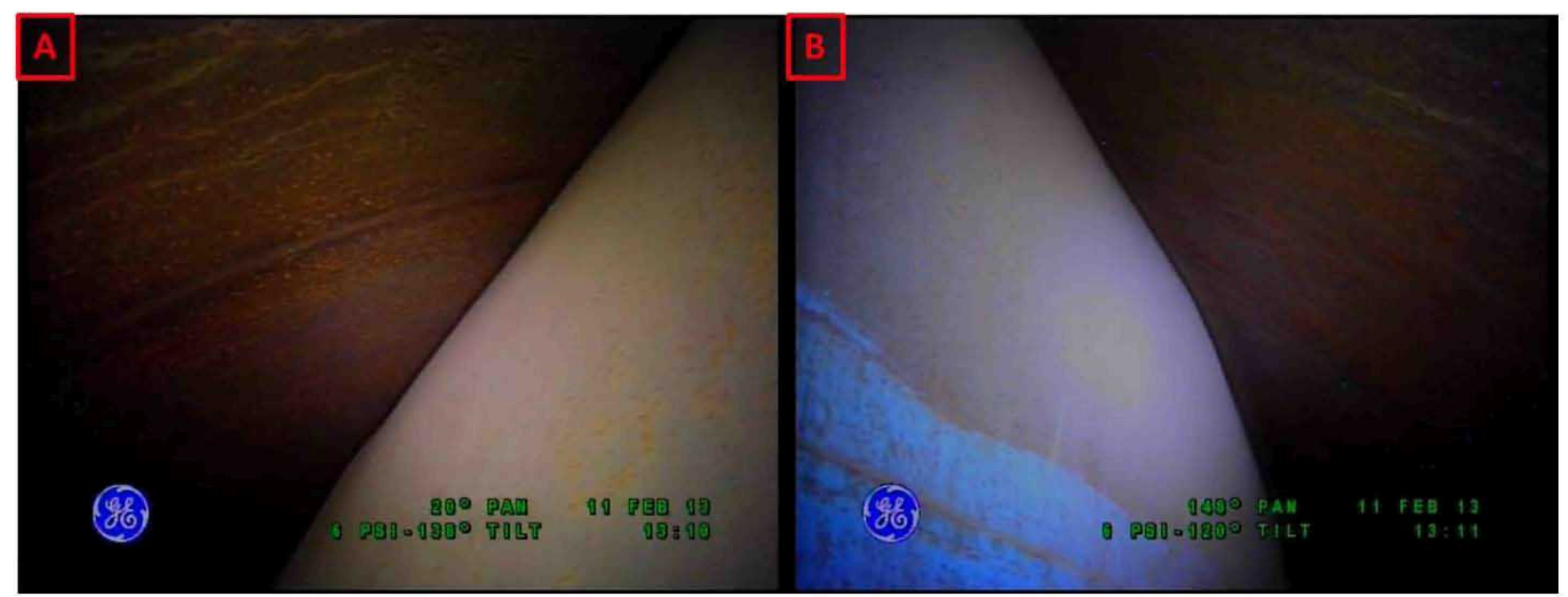

Figure 3-38. Riser 92 General Condition of the Upper Haunch on February 11, 2013 Looking Towards Riser 97 (A) and Looking Towards Riser 85 (B)

\section{Sidewall Comparison - Riser 92}

The sidewall of the primary tank appears to be in good condition and no areas of interest were identified on the primary tank sidewall during the 2013 inspection.

\section{Lower Knuckle and Annulus Floor Comparisons - Riser 92}

Figure 3-39 shows the general condition of the lower knuckle and annulus floor in February 2013. A beachline can also be seen along the annulus floor in Figure 3-39B which is likely the result of evaporated couplant water used during UT examinations. Figure 3-40 shows the general condition of the refractory slots in February 2013 and no anomalies were noted. No anomalies were identified on the lower knuckle of the primary tank, insulating refractory, refractory slots, stiffener ring, or annulus floor during the 2013 inspection.

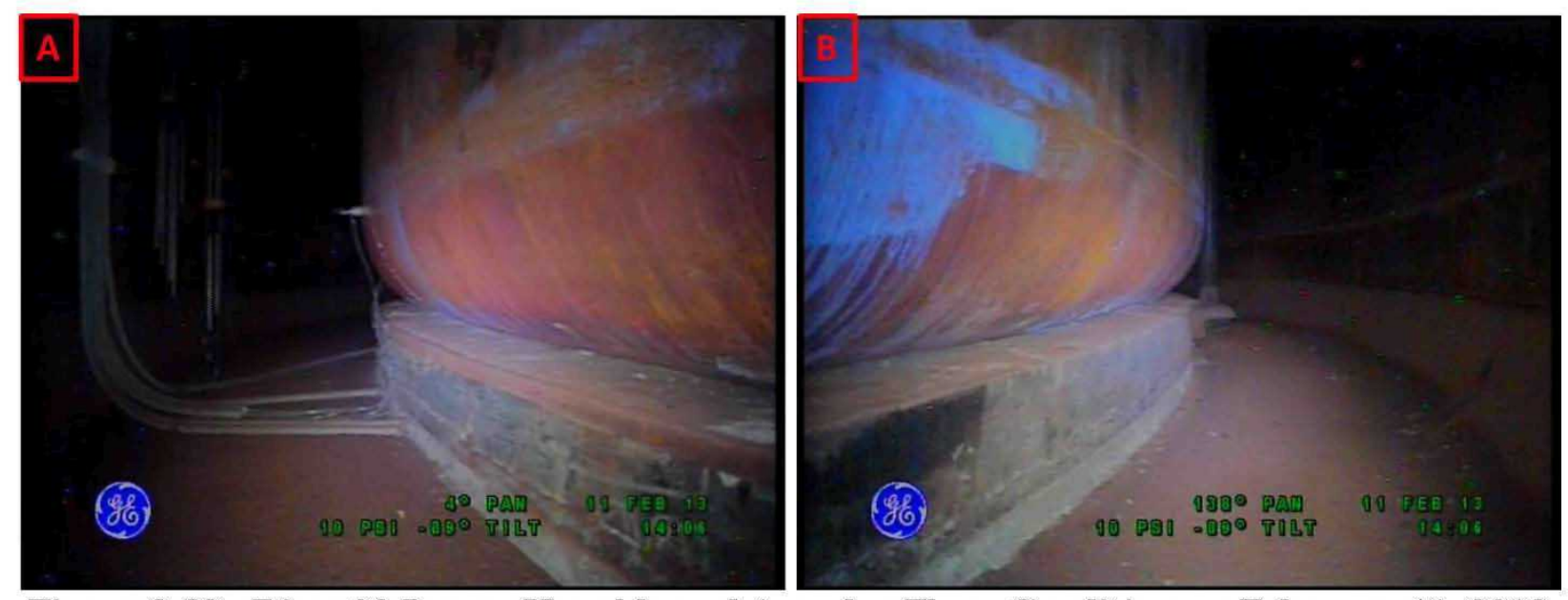

Figure 3-39. Riser 92 Lower Knuckle and Annulus Floor Condition on February 11, 2013 Looking Towards Riser 97 (A) and Looking Towards Riser 85 (B) 
RPP-RPT-54815, Rev. 0

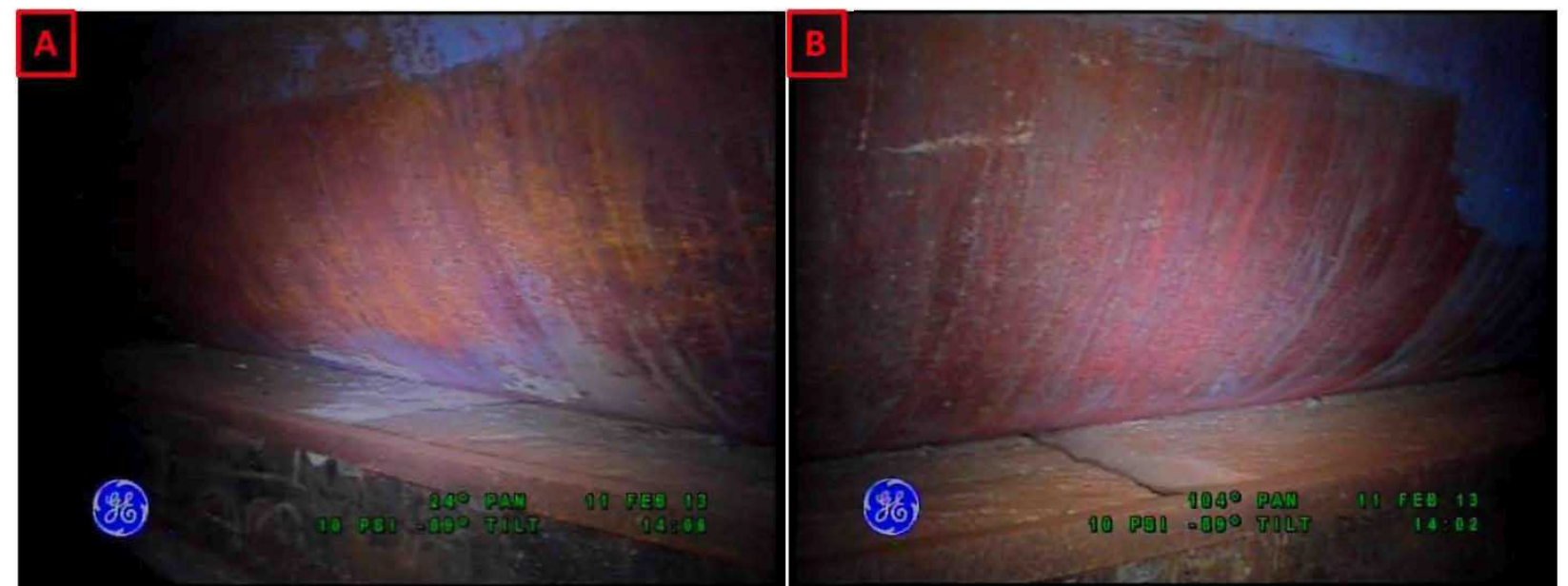

Figure 3-40. Riser 92 General Condition of the Refractory Slots on February 11, 2013 


\subsection{DISCUSSION}

In the risers where the annulus ENRAF is located, typically an area of discoloration can be seen on the annulus floor (see Figure 4-1 and Figure 4-2 for an example from tank AZ-102). The lighter area on the annulus floor is believed to be the result of the annulus ENRAF installation performed in 2003. During installation, compressed air was used to blow away any debris from the annulus floor at the bottom of the applicable riser (Work Package 2E-03-01479/M). After using compressed air, a mechanical grabber was then used to remove the debris. This lighter discoloration appears to be lower in elevation when compared to the darker annulus floor surrounding this area (see Figure 4-2D). The darker area appears to be corrosion product from the primary tank and secondary liner. In the center of the lighter region, there is typically a smaller rust stain which is located directly underneath the ENRAF plummet. This rust stain can be attributed to the accumulation of moisture resulting from air condensing in the ENRAF equipment located above grade. These anomalies seen in the ENRAF risers do not appear to be a region of concern.

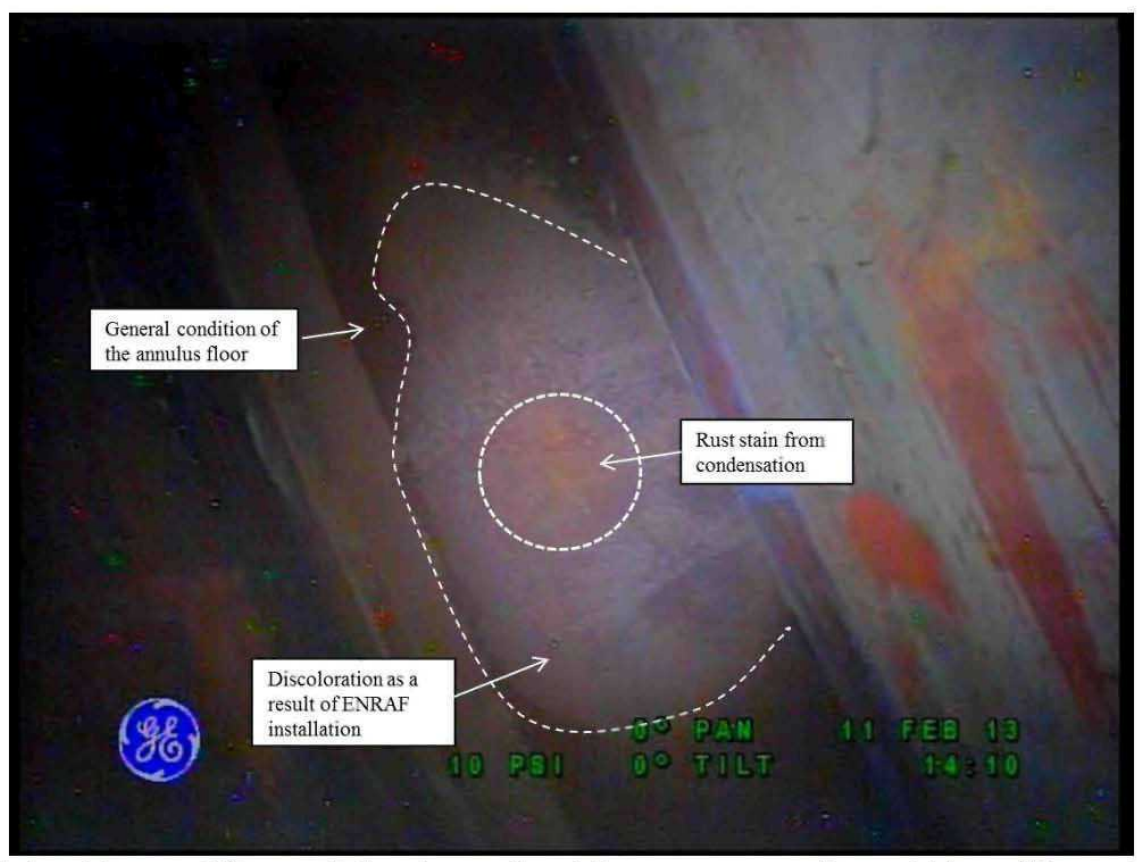

Figure 4-1. Top Down View of the Annulus Floor as seen from Riser 92 on February 11, 2013 


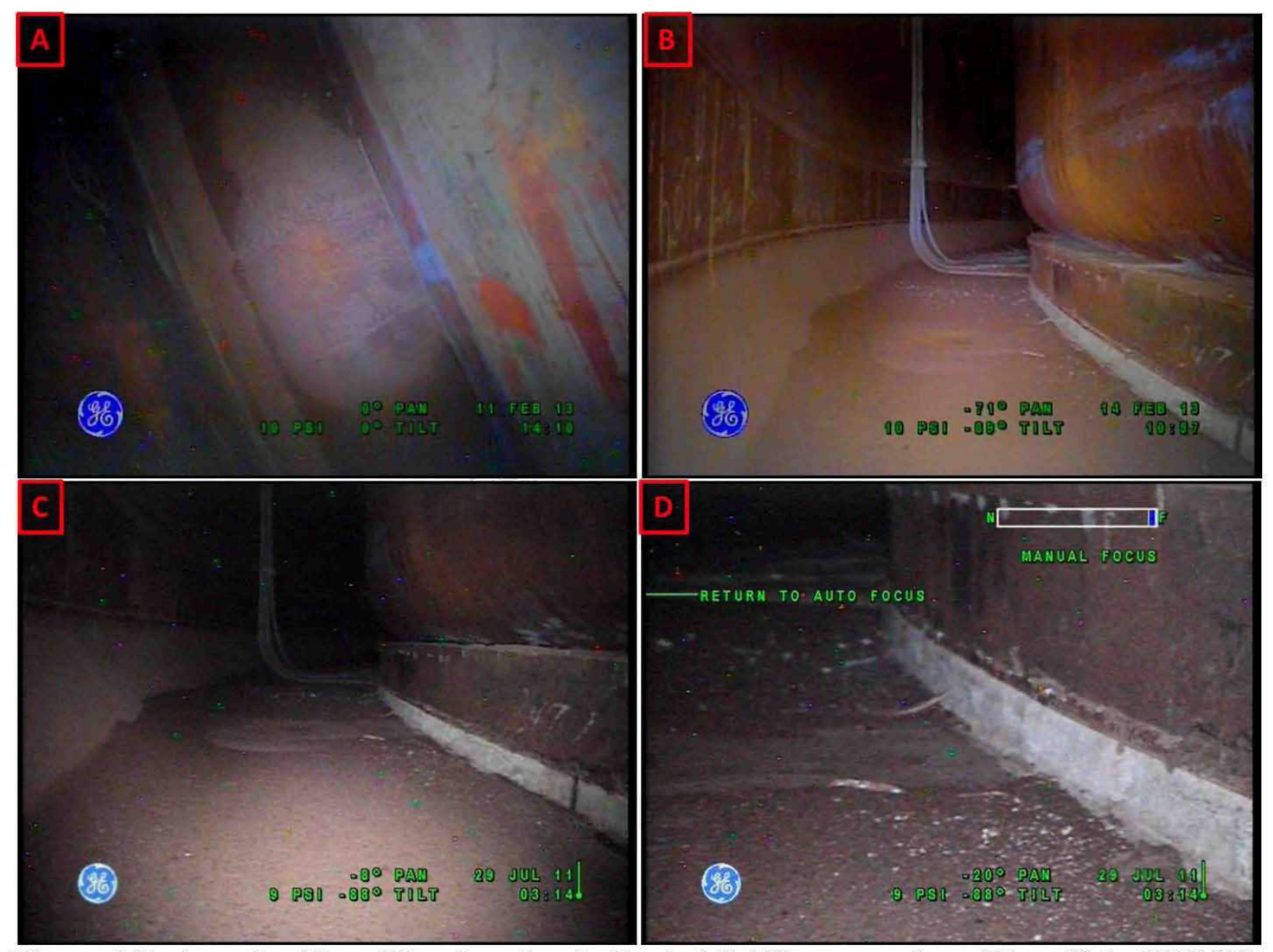

Figure 4-2. Annulus Floor Discoloration in Tank AZ-102 as seen from Riser 92 in 2013 (A), from Riser 80 in 2013 (B), from Riser 80 in 2011 (C), and Close Up View Showing Elevation Differences as seen from Riser 80 in 2011 (D) 


\subsection{CONCLUSIONS}

The eleven-riser enhanced visual inspection for each tank, AZ-101 and AZ-102, has found no areas of concern on the primary tank sidewall, lower knuckle, insulating refractory, refractory slots, stiffener ring, or annulus floor, which would be indicative of a primary tank leak. These inspections were performed during January 2013 and February 2013.

Annulus inspections identified small changes in appearance of the annulus floor of tanks AZ-101 and AZ-102 as compared to previous inspections. These changes are likely attributed to evaporated couplant water from UT examinations that occurred in nearby risers after the previous visual inspection. Additional stains were also identified on the annulus floor of tanks AZ-101 and AZ-102, however, these stains can be correlated back to existing equipment locations (e.g., annulus pump pit, riser penetrations, ENRAFs, etc.). Despite the changes identified during the current inspection, there was no evidence indicative of active water intrusion or a primary tank leak for tanks AZ-101 and AZ-102.

All changes identified on the annulus floor shall be tracked in RPP-RPT-34310, Double-Shell Tank Integrity Inspection Report for AZ Tank Farm, as part of the DST visual inspection program.

To date, no evidence exists that would indicate either the containment or structural integrity have been compromised in tanks AZ-101 and AZ-102. 
RPP-RPT-54815, Rev. 0

\subsection{REFERENCES}

H-2-67245, 1973, Concrete Tank Section \& Haunch Reinforcement, Rev. 1, U.S. Atomic Energy Commission, Richland, Washington.

H-2-67317, 2008, Tanks $101 \& 102$ Section \& Detalls 241-AZ Tank Farm, Rev. 2, Washington River Protection Solutions, LLC., Richland, Washington.

H-14-010507, 2006, Dome Penetration Schedules Tank 241-AZ-101, Rev. 13, Sheet 1, CH2M HILL Hanford Group, Inc., Richland, Washington.

H-14-010507, 2006, Dome Penetration Schedules Tank 241-AZ-102, Rev. 10, Sheet 2, CH2M HILL Hanford Group, Inc., Richland, Washington.

HNF-4819, 1999, Final Results of Double-Shell Tank 241-AZ-101 Ultrasonic Inspection, Rev. 0, Lockheed Martin Hanford Corporation, Richland, Washington.

PER-2013-0274, 2013, AZ-102 Annulus Leak Detector ENRAF, Washington River Protection Solutions, LLC., Richland, Washington.

RPP-15765, 2003, Ultrasonic Inspection Results for Double-Shell Tank 241-AZ-102-FY2003, Rev. 0, CH2M HILL Hanford Group, Inc., Richland, Washington.

RPP-ASMT-53793, 2011, Tank 241-AY-102 Leak Assessment Report, Rev. 0, Washington River Protection Solutions, LLC., Richland, Washington.

RPP-PLAN-46847, 2010, Visual Inspection Plan for Single-Shell Tanks and Double-Shell Tanks, Rev. 0, Washington River Protection Solutions, LLC., Richland, Washington.

RPP-RPT-34264, 2007, Ultrasonic Inspection Results for Double-Shell Tank 241-AZ-101FY2007, Rev. 0, CH2M HILL Hanford Group, Inc., Richland, Washington.

RPP-RPT-34310, 2007, Double-Shell Tank Integrity Inspection Report for 241-AZ Tank Farm, Rev. 0, Washington River Protection Solutions, LLC., Richland, Washington.

RPP-RPT-51020, 2012, Ultrasonic Inspection Results for Double-Shell Tank 241-AZ-102FY2012, Rev. 1, Washington River Protection Solutions, LLC., Richland, Washington.

WRPS-1204931, 2012, Double-Shell Tank 241-AY-102 Primary Tank Leak Extent of Condition Evaluation and Recommended Annulus Visual Inspection Intervals, Washington River Protection Solutions LLC., Richland, Washington. 